\title{
What is Kiranti?
}

\section{A Critical Account}

\author{
Pascal Gerber \\ Institut für Sprachwissenschaft, Universität Bern \\ pascal.gerber@isw.unibe.ch \\ Selin Grollmann \\ Institut für Sprachwissenschaft, Universität Bern \\ selin.grollmann@isw.unibe.ch
}

\begin{abstract}
This paper challenges the conventional views on the phylogeny of the bundle of languages of Eastern Nepal subsumed under the name 'Kiranti'. Contrary to the widespread belief that the group constitutes a stable, monophyletic subgroup of the Trans-Himalayan language family, the empirical evidence for the coherence of a Kiranti branch is remarkably limited. Additionally, the internal structure of the alleged Kiranti branch is to a large degree unclarified, despite a number of contributions to this topic. This paper aims to critically review the different subgrouping proposals and the potential shared innovations defining a coherent Kiranti subgroup within TransHimalayan. Furthermore, it will be shown that certain languages outside the Kiranti speaking area may be more closely related to certain Kiranti languages than those are to other Kiranti languages. The Kiranti branch constitutes a largely unsubstantiated subgroup and its phylogenetic coherence should not be taken for granted in work on Trans-Himalayan historical linguistics.
\end{abstract}

\section{Keywords}

Kiranti - historical-comparative linguistics - shared innovations - phylogeny - internal classification Trans-Himalayan

\section{Introduction}

The Kiranti languages are a group of Trans-Himalayan (also known as Tibeto-Burman or Sino-Tibetan) languages spoken in the Himalayan foothills of eastern Nepal in the region historically known as Kirã̃t or Kirāt (किराँत or किरात). The group includes approximately 30 languages. Table 1 presents a geographical list of Kiranti languages with the corresponding classificatory schemes by Michailovsky (1994), van Driem (2001), Opgenort $(2005,2011)$ and Bickel/Gaenszle (2015) ${ }^{1}$

1 The list represents the geographical distribution from West (Hayu) to East (Limbu). The letters in the columns indicate the phylogenetic classification as assumed by the respective author. The symbol $>$ indicates a subgrouping proposition, e.g. $W>N$

(C) PASCAL GERBER AND SELIN GROLLMANN, 2019| DOI:10.1163/2405478X-01101010

This is an open access article distributed under the terms of the prevailing CC-BY-NC license at the time of publication. 
TABLE 1 Geographical list of Kiranti languages and corresponding classificatory schemes

\begin{tabular}{|c|c|c|c|c|}
\hline Language & Michailovsky & van Driem & Opgenort & Bickel/Gaenszle \\
\hline Hayu & w & $\mathrm{W}>\mathrm{N}$ & $\mathrm{W}>\mathrm{F}$ & $\mathrm{W}>\mathrm{N}$ \\
\hline Sunwar & $\mathrm{w}$ & $\mathrm{W}>\mathrm{N}$ & $\mathrm{W}>\mathrm{N}$ & $\mathrm{W}>\mathrm{N}$ \\
\hline Bahing & $\mathrm{w}$ & $\mathrm{W}>\mathrm{N}$ & $\mathrm{W}>\mathrm{N}$ & $\mathrm{W}>\mathrm{N}$ \\
\hline Wambule & - & $\mathrm{W}>\mathrm{CH}$ & $\mathrm{W}>\mathrm{CH}$ & $\mathrm{W}>\mathrm{CH}$ \\
\hline Jero & - & $\mathrm{W}>\mathrm{CH}$ & $\mathrm{W}>\mathrm{CH}$ & $\mathrm{W}>\mathrm{CH}$ \\
\hline Thulung & $\mathrm{w}$ & $\mathrm{W}>\mathrm{M}$ & $\mathrm{W}>\mathrm{M}$ & $\mathrm{W}>\mathrm{M}$ \\
\hline Khaling & $\mathrm{w}$ & $\mathrm{W}>\mathrm{UD}$ & $\mathrm{W}>\mathrm{UD}$ & $\mathrm{W}>\mathrm{UD}$ \\
\hline Dumi & $\mathrm{w}$ & $\mathrm{W}>\mathrm{UD}$ & $\mathrm{W}>\mathrm{UD}$ & $\mathrm{W}>\mathrm{UD}$ \\
\hline Kohi & - & $\mathrm{W}>\mathrm{UD}$ & - & $\mathrm{W}>\mathrm{M}$ \\
\hline Tilung & - & $\mathrm{C}$ & $\mathrm{W}>\mathrm{M}$ & - \\
\hline Nachiring & - & $\mathrm{C}>\mathrm{KH}$ & - & $\mathrm{C}>\mathrm{KH}$ \\
\hline Kulung & $\mathrm{E}$ & $\mathrm{C}>\mathrm{KH}$ & $\mathrm{C}$ & $\mathrm{C}>\mathrm{KH}$ \\
\hline Chamling & $\mathrm{E}$ & $\mathrm{C}>\mathrm{S}$ & $\mathrm{C}$ & $\mathrm{C}>\mathrm{S}$ \\
\hline Puma & - & $\mathrm{C}>\mathrm{S}$ & - & $\mathrm{C}>\mathrm{S}$ \\
\hline Bantawa & $\mathrm{E}$ & $\mathrm{C}>\mathrm{S}$ & C & $\mathrm{C}>\mathrm{S}$ \\
\hline Sam & - & $\mathrm{C}>\mathrm{KH}$ & - & $\mathrm{C}>\mathrm{KH}$ \\
\hline Sampang & - & $\mathrm{C}>\mathrm{KH}$ & - & $\mathrm{C}>\mathrm{KH}$ \\
\hline Mewahang & - & $\mathrm{E}>\mathrm{UA}$ & - & $\mathrm{GE}>\mathrm{UA}$ \\
\hline Lohorung & - & $\mathrm{E}>\mathrm{UA}$ & - & $\mathrm{GE}>\mathrm{UA}$ \\
\hline Yamphu & - & $\mathrm{E}>\mathrm{UA}$ & $\mathrm{E}$ & $\mathrm{GE}>\mathrm{UA}$ \\
\hline Dungmali & - & $\mathrm{C}>\mathrm{S}$ & - & $\mathrm{C}>\mathrm{S}(?)$ \\
\hline Chintang & - & $\mathrm{C}>\mathrm{S}$ & - & $\mathrm{GE}>\mathrm{E}>\mathrm{GY}$ \\
\hline Chìlìng & - & $\mathrm{E}>\mathrm{GY}$ & - & $\mathrm{GE}>\mathrm{E}>\mathrm{GY}$ \\
\hline Athpahariya & - & $\mathrm{E}>\mathrm{GY}$ & - & $\mathrm{GE}>\mathrm{E}>\mathrm{GY}$ \\
\hline Belhare & - & $\mathrm{E}>\mathrm{GY}$ & - & $\mathrm{GE}>\mathrm{E}>\mathrm{GY}$ \\
\hline Yakkha & - & $\mathrm{E}>\mathrm{GY}$ & - & $\mathrm{GE}>\mathrm{E}>\mathrm{GY}$ \\
\hline Limbu & $\mathrm{E}$ & $\mathrm{L}$ & $\mathrm{E}$ & $\mathrm{GE}>\mathrm{E}>\mathrm{L}$ \\
\hline
\end{tabular}

The phylogenetic unity of the Kiranti languages under a single node in the Trans-Himalayan family has not been a matter of debate. The coherence of a Kiranti branch has generally been taken for granted in all classifications of the Trans-Himalayan language family (cf. Grierson 1909; Shafer 1955; Shafer 1974; Benedict 1972; van Driem 2001; Bradley 2002; Matisoff 2003; Thurgood 2003). However, a close examination

means Western $>$ Northwestern. The abbrevations used are $\mathrm{W}=$ Western, $\mathrm{C}=$ Central, $\mathrm{E}=$ Eastern, $\mathrm{GE}=\mathrm{Greater}$ Eastern, $\mathrm{L}=$ Limbu, $\mathrm{N}=$ Northern, $\mathrm{CH}=$ Chaurasiya, $\mathrm{M}=$ Mid, $\mathrm{F}=$ Far, UD = Upper Dudhkosi, $\mathrm{KH}=$ Khambu, $\mathrm{S}=$ Southern, UA = Upper Arun, GY = Greater Yakkha. The definition of the individual languages and the drawing of dialectal and language borders is a matter of considerable controversy. The Linguistic Survey of Nepal, carried out from 1981 to 1984 by the Deutsche Forschungsgemeinschaft in collaboration with Tribhuvan University (Kirtipur, Nepal), brought to life a considerable number of new names, many of which designate one and the same language or are clan names or toponyms rather than language names ( cf. van Driem 2001: 623). See section 2 for a discussion of the classifications given in Table 1. 
of the relevant publications reveals that the monophyletic status of Kiranti is by no means beyond reasonable doubts. On the contrary, the empirical evidence in favour of this assumption, that is shared linguistic innovations, is surprisingly small. In this paper, we aim to question the conventional view on the phylogeny of Kiranti with regard to its internal classification, its coherence and its extent. First, certain aspects pertaining to the internal classification of Kiranti are not fully convincing and need to be revised or abandoned. Second, the traditional definition of Kiranti may include numerous phylogenetic units rather than constituting a single clade. Third, the traditional definition possibly is too narrow and excludes languages which are more closely related with certain of the traditional subgroups than these subgroups are with other Kiranti groups.

In sum, we see little evidence at present to confidently assume a coherent, that is monophyletic, linguistic group assembling all the languages referred to as Kiranti. To achieve progress with regard to the classification of Kiranti languages, strict historical-comparative methodology needs to be employed. The phylogenetic unity of Kiranti may very well be the case, but so far, the evidence in favour of this assumption is not sufficient.

This paper is structured as follows. In the rest of this introductory section, we will briefly present an overview of the research on Kiranti $(\S 1.1)$ and discuss the tried-and-tested methodology to identify a group of languages as a coherent subgroup within a language family $(\S 1.2)$. Section 2 summarises what is known about the internal structure of the presumable Kiranti branch and critically reviews existing subgrouping proposals. Section 3 focuses on the evidence for Kiranti as a coherent, monophyletic branch and shows that a considerable part of the evidence presented so far is not convincing. Section 4 discusses the expansion of Kiranti to include three languages which are not traditionally considered to belong to Kiranti, that is Lhokpu, Dhimal and Toto. Section 5 provides a summary and outlook.

\subsection{Research on Kiranti}

The first linguistic data on Kiranti languages were collected by orientalist and British Resident in Kathmandu Brian Houghton Hodgson $(1857,1858)$, who published word lists of 18 Kiranti languages, namely Hayu, 'Báhinggyá', 'Chouras'ya' (= Wambule/Jero), 'Thulungg'ya', 'Kháling', 'Dúmi', 'Ródóng/ Chámling', 'Dúngmáli', 'Wáling,, 'Rúngchhénbúng', 'Chhingtángya' (the latter three all = 'Bontáwa'), 'Sángpáng, 'Náchheréng,' 'Kulúng’ya, ‘Báláli' (= Mewahang), 'Lóhóróng,' 'Yákha', 'Lámbichhóng’ (both = Yakkha) and provided grammatical descriptions of Bahing and Hayu. Early accounts on the classification of Kiranti were provided by Konow (Grierson 1909) and Shafer (1953), based on the data of Hodgson and supplemented with some new data. A linguistic survey by the Deutsche Forschungsgemeinschaft and Tribhuvan University, Kirtipur, Nepal, from 1981 to 1984 collected elicitated data on a variety of Kiranti languages which were used in tentative classifications (Winter 1986a, 1987, 1991; Hanßon 1991). Starting in the 1970s, extensive linguistic and anthropological field work was undertaken and comprehensive grammars and concise grammatical sketches were written on Thulung (Allen 1975; Lahaussois 2002), Limbu (Weidert/Subba 1985; van Driem 1987), Hayu (Michailovsky 1988), Dumi (van Driem 1993a; Rai 2017), Athpahariya (Ebert 1997a), Chamling (Ebert 1997b; Singh Rai 2012), Yamphu (Rutgers 1998), Belhare (Bickel 2003), Wambule (Opgenort 2004a), Jero (Opgenort 2005), Kulung (Tolsma 2006), Sunwar (Borchers 2008), Bantawa (Doornenbal 2009), Chintang (Rāī et al. VS 2067 [2011]), Tilung (Opgenort 2014), Kohi (=Koyi, Koyu) (Lahaussois 2009), Puma (Sharma 2014) and Yakkha (Schackow 2015). Further grammars are in preparation on Lohorung (van Driem et al.), Nachiring (Selin Grollmann), Mewahang (Pascal Gerber) and Sampang (René Huysmans). There are also a number of publications on individual Kiranti languages by native scholars, mostly written in Nepali. 
A number of publications on typological and structural aspects of Kiranti languages are also available, e.g. on agreement morphology (Michailovsky 1975; Genetti 1988, 1992; van Driem 1988, 1994, 1997; Ebert 1991; DeLancey 1992; Bickel et al. 2007a, 2007b; Huysmans 2011; Jacques et al. 2012), tense-aspect-mood (van Driem 1993b; Bickel 1996), nominalisation and subordination (Ebert 1993; Bickel 1999; Lahaussois 2003; Watters 2008; Schackow et al. 2012), spatial orientation and demonstratives (Allen 1972; Bickel 1997, 2001; Ebert 1999; Jacques/Lahaussois 2014) or negation (van der Auwera/Vossen 2017) as well as the general overviews by Ebert (2003); Ebert/Gaenszle (2008) and Michailovsky (2017). Historicalcomparative work on Kiranti languages is rare, the respective contributions being discussed in sections 2 and 3 .

Many Kiranti languages are critically endangered, since speakers especially of smaller Kiranti languages are switching to more dominant Kiranti languages or Nepali, the Indo-Aryan national language and lingua franca of Nepal (cf. for example Grollmann 2018).

\subsection{Methods of Historical-Comparative Linguistics}

The methods of historical-comparative linguistics, established in the study of Indo-European since the nineteenth century and applied to a number of other language families, enable linguists to qualify linguistic kinship by systematically comparing related languages, reconstructing their common mother tongue and establishing a family tree by means of shared non-trivial linguistic innovations. While there are several other reasons for structural similarities between any two languages, whether related or unrelated, namely chance, borrowing or typological universal tendencies, only shared innovations in the phonology, morphosyntax or lexicon justify the grouping of the languages in question into the same subgroup of the language family. Shared innovations indicate that the languages in question reflect the same language change and therefore arose from a common intermediate linguistic ancestor. Any two or more languages which do not share the innovation are not more closely related. The failure to show the reflex of a linguistic innovation indicates that the language in question does not belong to the subgroup held together by the shared innovation, i.e. it belongs to a residue group, but says nothing about the closer affiliation of the language within the language family.

A prime example of rigorous historical-comparative methodology is found in the internal classification of the Semitic languages. For illustration, we will focus on the Northwest subgroup. The Northwest Semitic languages, i.e. Ugaritic, Canaanite and Aramaic, are defined by the shared development of the double plural marking of $q V t l$ nouns in that both $a$-insertion between the final two consonants and an external suffixed plural marker code plurality. While $a$-insertion is common to the Semitic languages, the obligatory combination of the two plural markings in $q V t l$ nouns and its restriction to this class of nouns is an exclusive and therefore defining shared innovation of the Northwest Semitic branch (cf. Huehnergard 1991: 284-285). The lack of double plural marking, however, does not entail that other Semitic groups, such as Arabic, South or East Semitic are more closely related to each other just because they did not participate in this innovation. Rather, these other languages can be defined as a residue group, i.e. their relationship to each other and their development from Proto-Semitic cannot be specified any further with regard to this particular development. ${ }^{2}$ Only considering double plural marking, these languages therefore need to be linked directly to Proto-Semitic in a flat family tree, as shown in Figure 1.

2 Additional shared innovations allow for a detailed classification of Semitic with a binary split into East and West and further branching of West into South and Central, the latter further dividing into Arabic and Northwest (cf. Hetzron 1972, 1973, 1975, 1976; Huehnergard 1991; Faber 1997). 


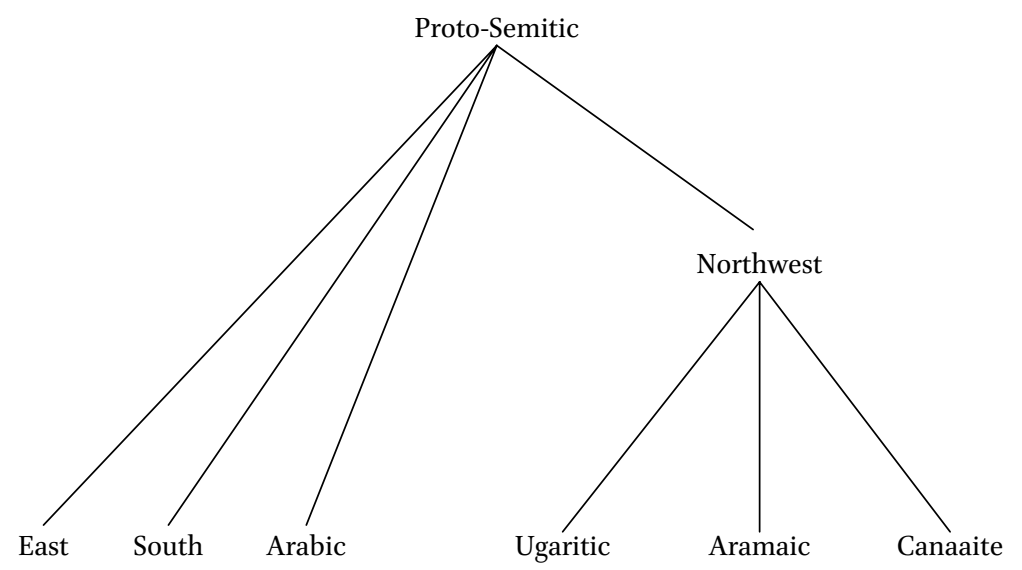

FIGURE 1 Family tree representation of Semitic

What makes the argument for identifying the Northwest Semitic languages as a subgroup particularly strong is that morphological innovations are involved. As Meillet (1925) and Campbell/Poser (2008) point out, out of three arguments for subgrouping, i.e. lexical innovations, regular sound correspondences and shared morphological innovations, morphological innovations, particularly in the form of shared aberrancies, are the strongest arguments (cf. also van Boxhorn 1647).

Despite regular criticism of either the premises, the value and scope or technical aspects (cf. e.g. Schmidt 1872; Schuchardt 1885; Greenberg 1987, 2000; Wang 1969; Weinreich/Labov/Herzog 1968; Dixon 1997; Nichols 1992; Durie/Ross 1996; Harrison 2003; François 2015), ${ }^{3}$ the traditional methods of historicalcomparative linguistics along with their premises and ramifications remain valid and can be applied to different language families around the world with convincing results, e.g. Austronesian (Brandstetter 1893; Dempwolff 1934-1938; Blust 1970, 1980, 1983, 1986, 1989, 1991, 1993; Crowley 1991), Australian (Bowern/ Koch 2004), Algonquian (Bloomfield 1925, 1928) or Uto-Aztecan (Sapir 1913, 1915). Therefore, any serious attempt at the classification of Kiranti must draw upon this methodology.

\section{Internal Classification of Kiranti}

In this section, we will present and review proposals on the internal classification, i.e. the subgrouping, of Kiranti languages. Historical-comparative research on Kiranti has brought forth a number of contributions, but the individual contributions are often in conflict with each other by postulating different subgroups or arriving at similar solutions without referring to or elaborating on earlier work. As a consequence, we will discuss the individual contributions separately in $\S 2.2-2.5$, reviewing the evidence of Michailovsky (1994), van Driem (199ob, 2001), Opgenort (2004b, 2005, 2011, 2014) and Bickel/Gaenszle (2015) respectively. To start our discussion, however, we will first briefly go through earlier classification schemes in $§$ 2.1, namely those by Konow in the Linguistic Survey of India (Grierson 1909), Shafer (1953, 1955, 1974), Winter (1986a, 1987, 1991) and Hanßon (1991). Since these authors do not provide systematic and convincing linguistic evidence for their subgrouping, their classifications cannot be falsified and will therefore not be reviewed in greater detail.

3 Criticism on the comparative method and the tree model in Trans-Himalayan historical linguistics is expressed for example by Benedict (1973), Ebert (1990), LaPolla (2001), Matisoff (2003) or Tournadre (2014). 


\subsection{Early Classifications (Konow, Shafer, Winter, Hanßon)}

All classificatory schemes recognise different subgroups, usually along geographical lines and terms. The earliest classification was the assumption of an 'Eastern sub-group of the complex pronominalized languages' 4 by Sten Konow in the Linguistic Survey of India (cf. Grierson 1909: 273), based on the comparative word lists of Hodgson (1857). ${ }^{5}$ Konow's group, while including most of the languages which are still considered to belong to Kiranti, also assembled languages which were later excluded from Kiranti, e.g. Dhimal, Thangmi, Baram ('Bhramu'), Thakali ('Thāksya'), Chepang or the non-Trans-Himalayan isolate Kusunda. ${ }^{6}$ No evidence other than the shared feature of 'complex pronominalization' is given by Konow to justify his classification.

Shafer $(1953,1955,1974)$ modified Konow's classification in a number of specific points, namely by excluding Kusunda, Chepang, Dhimal, Thakali, Hayu ('Vayu') and Thangmi-Baram, and coined the name 'East Himalayish' for the remaining group of languages. The classification by Shafer (1953: 356-357) assumes a binary branching into a Western and Eastern branch of East Himalayish. The Western branch consists of four 'Units', i.e. 'Bahing,' 'Thulung, 'Tśaurasya' and 'Dumi'. The Eastern Branch is divided into two 'Units', 'Khambu' and 'Bontawa'.

The classification by Shafer is not supported by convincing linguistic evidence except for the primary binary branching into Western and Eastern, which is based on sound correspondences observed for the stop series and the rhotics, although they are never worked out or described in any systematic way by Shafer. These sound correspondences were later elaborated more systematically by van Driem (199ob, 2001) and Michailovsky (1994) (cf. § 2.2 and 2.3).

Alternative classifications were proposed by Winter (1986a, 1987, 1991) and Hanßon (1991). Winter (1986a, 1987, 1991), based on the findings of the Linguistic Survey of Nepal, presents non-lexical isoglosses between a number of 'Rai idioms' and draws some preliminary conclusions about the internal classification of the Rai languages. ${ }^{7}$ Winter (1987) is the most elaborate treatment and presents seventeen nonlexical isoglosses, both phonological and morphological. Winter (1991) adds isoglosses pertaining to verb stems and presents a more detailed account on the internal structure of Rai. He assumes several groups, namely 'Bantawa-Dungmali-Chamling-Hangkhim,' 'Dumi-Koi', 'Bahing,' 'Khaling', 'Thulung-Umbule' and 'Kulung-Nachiring' (cf. Winter 1991: 154-155). Whereas the first group is a clearly identifiable and delimited group, the latter four groups also show affinities with each other. Dumi-Koi is somewhat loosely linked to Khaling, Thulung-Umbule and Bahing, the latter in turn being tightly linked to Thulung-Umbule and somewhat distantly linked to Kulung-Nachiring and Khaling (cf. Winter 1991: 155). The conclusions of Winter generally match the classification by other scholars and reflect the same phylogenetic entities as van Driem's (2001) 'Southern' (= Bantawa-Dungmali-Chamling-Hangkhim), 'Khambu' (= KulungNachiring) and 'Upper Dudhkosi' (= Dumi-Koi and Khaling) groups and the Western group consisting of Chaurasiya and Bahing-Sunwar(-Hayu) defined by the development ${ }^{*} k w>6 \sim ? w$ (see $\S 2.2$ and 2.4). However, the details of the classification of Winter are not endorsed by subsequent scholars, for example

4 The term 'pronomenalised' was coined by Hodgson (1856) to refer to languages with verb agreement. The designation implies that the agreement morphemes derive from free personal pronouns. This etymological analysis is no longer preferred nowadays, but the term is still used due to adherence to the terminological tradition initiated by Hodgson.

5 Hodgson (1857) did not himself propose any internal classification of Kiranti. On the contrary, "Hodgson's vocabulary [...] contains a jumble of dialects, those in adjoining columns seldom being closely related to each other" (Shafer 1953: 356).

6 The view that Hayu, added by Konow to his Eastern sub-group "as a kind of appendix" (Grierson 1909: 274), may be less closely related to the other Kiranti languages lived on for a long time after Konow's classification (cf. Shafer 1953; Benedict 1972: 5-8; Winter 1987: 729). Michailovsky (1994: 766) finally integrated Hayu in Kiranti, but did so with reservations.

7 Rai is a cover term for all Kiranti languages except for Limbu, Yakkha and Sunwar (cf. § 3.1). 
the exclusion of Khaling from the Dumi-Kohi cluster, the separation of Southern and Khambu, and the lack of links between Khambu and Upper Dudhkosi. Furthermore, his comparison is very preliminary and based on the percentage of shared features instead of defining shared innovations. Winter (1986a) views Bantawa as a conservative Rai language with regard to the stop inventory, but the work of later scholars (van Driem 199ob; Michailovsky 1994; Opgenort 2011) has shown that Bantawa, alongside the other Central and Eastern Kiranti languages, is a markedly innovative Kiranti language with regard to the stop inventory.

A more comprehensive account on Kiranti phylogeny based on the findings of the Linguistic Survey of Nepal is Hanßon (1991: 110-113), who presents a preliminary classification of all Kiranti languages, not just of a selection of Rai languages. He divides Kiranti into an Eastern, Central and Western branch.

The Eastern branch splits into Eastern, i.e. Limbu, South-Western, i.e. Athpahariya, Belhare, 'Chhulung' (= Chiling), Chintang and Yakkha, and North-Western, i.e. Lohorung and Yamphu. Central Kiranti is divided into Southern, which contains Bantawa, Puma and Chamling, North-Eastern, namely Mewahang and Sam, and North-Western, that is Kulung, 'Sangpang' (= Sampang) and Nachiring, alongside a Northern intermediate subgroup and a marginal subgroup containing Dungmali. Western Kiranti, according to Hanßon (1991:112), consists of a Southern subgroup, i.e. Chaurasiya, an Eastern subgroup, that is Thulung and 'Lingkhim', a Western subgroup with Bahing and Sunwar, a marginal Northern subgroup with Khaling, Dumi and Kohi, a marginal Western subgroup with Hayu and a 'marginal Halesidanda' subgroup with Tilung. Additionally, there is a large number of languages with are left unclassified due to insufficient data (Hanßon 1991: 112-113). Most of the subgroups of Hanßon (1991), like those of Winter, correspond roughly to groups assumed by other scholars based on a more systematic and convincing methodology of comparison. However, certain low-level groups are demonstrably false. Most noteworthy, Mewahang does not belong to Central Kiranti, but is most closely related to Lohorung, and Tilung is most closely related to Thulung and should not be assigned a separate subgroup (cf. Opgenort 2011). The classification of Hanßon (1991) is mostly neglected by subsequent scholars due to the lack of empirical substantiation and the imprecision of the low-level classification. In the following, contributions with a more systematic methodology and empirical evidence will be discussed.

\subsection{Michailovsky (1994): The Binary Western-Eastern Split}

Michailovsky (1994) classifies the Kiranti languages into a 'Western' and an 'Eastern' subgroup on the basis of phonological arguments. Michailovsky (1994) assumes four places of articulation for stops in Proto-Kiranti, namely bilabial, dental, palatal and velar, and three series of stops for each place, i.e. voiced, voiceless and aspirated. According to Michailovsky (1994), the Eastern Kiranti languages, which are represented in his paper by Kulung, Chamling, Bantawa and Limbu, underwent a series of sound changes affecting the stops, whereas Western Kiranti languages, represented in his paper by Hayu, Bahing, Sunwar, Dumi and Khaling, retain the stops unchanged. Thulung occupies an intermediate position between Western and Eastern Kiranti. The changes identified by Michailovsky (1994) are the following. ${ }^{8}$

1. Glottalisation of the Proto-Kiranti voiceless ${ }^{*} p$ and ${ }^{*} t$ in Eastern Kiranti and Pre-Thulung, but not in Limbu

2. Aspiration of all Proto-Kiranti voiceless stops in Limbu and, independently, of ${ }^{*} c$ and $* k$ in the other Eastern Kiranti languages

8 Note that these sound correspondences were already observed by Shafer (1953:358-36o), but no systematic treatment and subsequent classification is provided by Shafer. 
3. Devoicing of the Proto-Kiranti voiced stop series in Eastern Kiranti and, independently, in Limbu, but not in Thulung

4. Voicing of the glottalised labial and dental stops in Thulung and, independently, Eastern Kiranti

Another sound correspondence set up by Michailovsky (1994: 768) is Bahing ${ }^{7} b$ : Sunwar ${ }^{7} b \sim^{7} w$ : Thulung $p$, for which he assumes a Proto-Kiranti cluster ${ }^{*} k w$ which became a labial implosive $b$ in Proto-Western Kiranti, transcribed by Michailovsky (1994) as $<^{2} \mathrm{~b}>$.

Methodologically, the justification for a coherent Eastern branch is much more compelling than the one for a Western branch. The Eastern Kiranti languages share the glottalisation of Proto-Kiranti voiceless ${ }^{*} p$ and ${ }^{*} t$ and the devoicing of the Proto-Kiranti voiced stops. For the Western Kiranti languages, however, the sound correspondences only exhibit a single shared phonological innovation, namely the change of Proto-Kiranti ${ }^{*} k w>$ Proto-Western-Kiranti ${ }^{*} 6$. However, as will be shown in $\S 2.4$, this is a speculative assumption and does not include all Western Kiranti languages.

A problem of Michailovsky's (1994) proposal is the assumption of a number of parallel, independent changes which is required in order to explain the sound correspondences between Western and Eastern Kiranti languages (cf. § 2.6). Still, the findings of Michailovsky (1994) are adapted in all subsequent classifications and comparative work on Kiranti, since his basic and somewhat agnostic Western-Eastern dichotomy constitutes a convincing common ground on which the more finely-branched proposals of other scholars are based.

\subsection{The Classification of van Driem (199ob, 2001)}

Van Driem (2001: 615) provides a general classification of Kiranti languages with four subgroups, namely Western, Central, Eastern and Limbu. The eastern Kiranti subgroup of Michailovsky (1994) is divided by van Driem (2001) into three different subgroups, namely Central, Eastern and Limbu. Western Kiranti further branches into four subgroups, namely Northwestern, that is Hayu, Sunwar and Bahing, Chaurasiya, including Wambule and Jero, Midwestern with the sole member Thulung and the Upper Dudhkosi group, i.e. Dumi, Kohi and Khaling. Central is further divided into a Khambu and a Southern subgroup, the former including Kulung, Nachiring, Sampang and Sam, the latter Bantawa, Puma, Chamling, Chintang and Dungmali. Eastern Kiranti branches into Greater Yakkha, with Yakkha, Chiling and Athpahariya, and Upper Arun, with Lohorung, Yamphu and Mewahang. Limbu is split into two subgroups, named Eastern and Western Limbu. The classification is based on 'sound laws, on what is known of grammar and morphology, and on the ethnic divisions recognised by Kiranti peoples themselves' (van Driem, 2001: 615). A prominent explicit argument for an Eastern subgroup is the sound change ${ }^{*} r>y$ [j] in Eastern Kiranti, namely Limbu, Greater Yakkha and Upper Arun, discussed in van Driem (199ob). ${ }^{9}$ A consequence of this lenition is the reanalysis of the phonemes $r$ and $l$ as complementary allophones of a single phoneme in Eastern Kiranti, e.g. Limbu or Yamphu (cf. van Driem 199ob: 83-84). This sets apart the Upper Arun, Greater Yakkha and Limbu languages from the rest of Kiranti, namely Western and Central. ${ }^{10}$

9 Again, this sound change was already observed by Shafer (1953), who stated rather vaguely that '[...] $r$ - is generally retained in the Western Branch and in Rodong, that it may have become $r$ grasseyé in the Khambu Unit, and that it tends to become $y$ in the other dialects of the Eastern Branch' (Shafer 1953:362). In Winter (1986b, 1987), the development * $r>y$ is discussed, too.

See $\S 2.6$ for a discussion of problems regarding the relative chronology of this sound change and the stop changes described by Michailovsky (1994). 
While the sound change ${ }^{*} r>y$ in Eastern Kiranti is widely attested in these languages, diachronic complications arise from the fact that non-Eastern languages, notably Wambule, Jero, Bahing, Sunwar, Hayu, Thulung and Bantawa (cf. Winter 1986b; Opgenort 2005: 13), sometimes also show the reflex $y$ where ${ }^{*} r$ should be reconstructed and that Eastern languages sometimes show $r$ where they should evince $y$. The former problem is already evident from the comparative tables in Shafer (1953: 361) and is treated in detail by Opgenort $(2005,2011)$, see $§ 2.4$. The latter problem is explained by van Driem (2001: 618 ) with the assumption of a second rhotic phoneme for Proto-Kiranti, namely a uvular or velar fricative or trill, here represented by ${ }^{*} R$.

The distinction of two rhotics is retained in Khambu, since Sampang and Kulung both show $g$ as reflex of ${ }^{*} R$, but $r$ as reflex of ${ }^{*} r,{ }^{11}$ and in Yakkha, which shows $r$ as reflex of ${ }^{*} R$ (van Driem 2001: 618). However, no insights on the internal classification can be gained from the reconstruction of two different rhotics, since the distinction in Khambu constitutes a retention, and the merger of the two rhotics in several Kiranti groups probably reflects parallel, independent developments. Additionally, the distinction between ${ }^{*} r$ and ${ }^{*} R$ in Yakkha, with ${ }^{*} r>y$ and ${ }^{*} R>r$, for example in the verbs 'stand' vs. 'laugh' (van Driem 2001: 618), does not hold, at least not for the Tumok dialect described in the Yakkha grammar of Schackow (2015), where both 'stand' and 'laugh' evince an initial palatal glide $y$, i.e. yep- and yunca-.

Another aspect concerning the liquids in Kiranti is the development of ${ }^{*} r$ and ${ }^{*} l$ in final position discussed by van Driem (2001: 618). Final * $r$ interacts morphophonologically with final $n$ and $t$ in Limbu, Southern and Eastern Kiranti. Final *l, on the other hand, is preserved as such in Khambu, but became $n$ in Limbu, Eastern Kiranti and the Southern language Dungmali, whereas other Southern Kiranti languages show $\eta$. This sound correspondence, however, has not yet been shown to be regular, exemplified with only one instance by van Driem (2001), namely the word for village. Its significance would be low even if it would be shown to be regular, since it again only pertains to the Eastern group of Kiranti languages.

The classification of van Driem (2001: 615) constitutes a finely-branched tree of Kiranti, but all of his arguments except for the sound laws are problematic. Ethnic divisions cannot be put on a par with linguistic shared innovations with regard to linguistic classification. Similarities in grammar and morphology need to constitute shared innovations, too, and are meaningless if representing shared retentions or parallel developments. Van Driem (2001) does not provide explicit shared innovations for most of his subgroups, which therefore cannot be upheld, for example the Eastern subgroups Greater Yakkha and Upper Arun, the Central and Western Kiranti branches as well as the Western subgroups Chaurasiya, Upper Dudhkosi and Northwestern. For Upper Dudhkosi, i.e. Dumi, Kohi and Khaling, van Driem (2001: 711) mentions the existence of shared phonological innovations, but he fails to provide the data underpinning his statement. Lahaussois (2009: 1) shows that Kohi, unlike Khaling and Dumi, but like Thulung and Tilung, underwent the change of Proto-Kiranti ${ }^{*} p>b$ (cf. § 2.6), and also observes that several morphological markers of Kohi and Dumi are different. In sum, van Driem's historicalcomparative contribution justifies an Eastern branch, but his low-level classification lacks empirical evidence.

11 For Nachiring, the third Khambu language, van Driem (2001: 618), based on the Tables of Shafer (1953), assumes the sound value $\langle\mathrm{hr}\rangle$ as reflex of ${ }^{*} R$. However, the exact phonetic value of this sound is unclear, and new data shows that Nachiring merged the distinction and shows $r$ in instances where ${ }^{*}$ can be reconstructed (cf. Grollmann 2018: 12). Therefore, the distinction between $r$ and $R$ was probably upheld in Proto-Khambu and the change of $R$ to $g$ in Kulung and Sampang and the merger in Nachiring with $r$ postdates the split of Proto-Khambu (cf. Grollmann 2018: 12). 


\section{$2.4 \quad$ The Classification of Opgenort (2004b, 2005, 2011, 2014)}

Opgenort (2004b, 2005, 2011, 2014) presents phonological, lexical and morphological evidence for the internal classification of Kiranti. Opgenort (2004b) discusses the change of Proto-Kiranti * $k w>$ ProtoWestern Kiranti ${ }^{*} ? w$ as a potential shared innovation of Western Kiranti from the viewpoint of Wambule. Opgenort $(2005,2011,2014)$ further provides a classification of Kiranti on the basis of sound changes concerning the initial stops and can be viewed as an elaboration and update of Michailovsky (1994) and van Driem (199ob, 2001). Generally, Opgenort follows the binary opposition between Western and Eastern by Michailovsky (1994), but also reproduces the classification of van Driem (2001). Opgenort (2011, 2014) provides a grammatical sketch of Tilung and asserts the phylogenetic position of the language within Kiranti, concluding that it is most likely closely related to Thulung, sharing the sound change ${ }^{*} p>b$ and ${ }^{*} t>d$ with Thulung. ${ }^{12}$

Preglottalised stops Opgenort (2004b, 2005, 2011, 2014) assumes the existence of another stop series for Proto-Kiranti, namely a preglottalised voiceless series. This reconstruction is based on the observation that the sound correspondences between Western Kiranti $p$ and $t$ : Eastern Kiranti $p$ and $t$ exist besides the sound correspondences noted by Shafer (1953) and Michailovsky (1994) between Western Kiranti $p$ and $t$ : Thulung $b$ and $d$ : Eastern $b$ and $d$ : Limbu $p h$ and $t$. Since no conditioning environment for this overlap is detectable, Opgenort (2004b: 17-19) concludes that the former sound correspondence reflects Proto-Kiranti ${ }^{*} p$ and ${ }^{*} t$, whereas the latter reflects Proto-Kiranti ${ }^{*} ? p$ and ${ }^{*} ? t$. The sound change of preglottalisation assumed by Michailovsky (1994) is, then, no longer a shared innovation of Eastern Kiranti, but a shared retention. However, Eastern Kiranti is still defined by the subsequent sound changes, e.g. the devoicing of the inherited voiced series and the change of the preglottalised stops to voiced in Eastern Kiranti and voiceless aspirated in Limbu. A more significant consequence of this new reconstruction is the assumption of a shared innovation of Western Kiranti languages, namely the deglottalisation of the preglottalised series to plain voiceless stops. The reconstruction of a preglottalised series is also advocated for by Starostin (1994) and is implicitly assumed by Bickel/Gaenszle (2015) (see § 2.5), but criticised by Jacques (2017: 191) on the grounds that there is almost no instance of the correspondences between Western $p$ and $t$ : Eastern $p$ and $t$ and therefore no evidence for the reconstruction of ${ }^{*} p$ and ${ }^{*} t$ as distinct proto-phonemes. Additionally, Jacques (2017: 191) points out other irregular sound correspondences between Western and Eastern Kiranti and concludes that it is not helpful to reconstruct a separate protophoneme for each of these correspondences. Rather, conditioning environments should be investigated, some of which may involve morphologically complex structures (cf. Jacques 2017: 191-193). The reconstruction of a phonemic difference between plain and preglottalised voiceless stops therefore is uncertain and not convincing.

Rhotics Another phonological topic of Opgenort's historical-comparative research involves the rhotics. As pointed out above in $\S 2.3$, the necessity to assume two different rhotic sounds for Proto-Kiranti and the existence of irregular reflexes has already been detected by van Driem (2001). Opgenort (2005: 13, 34-36) likewise and without reference to van Driem (2001), assumes two different rhotic elements for Proto-Kiranti, namely ${ }^{*} r$ and ${ }^{*} r y$, a cluster of [r] with a palatal glide [j], to explain the irregularities in the reflexes. Proto-Kiranti ${ }^{*} r$, according to Opgenort (2005:34-35), is reflected in the sound correspondences between Western Kiranti $r$ : Eastern Kiranti $y$, whereas Proto-Kiranti * $r y$ is reflected in the sound correspondences where Western and Central Kiranti languages have either $r$ or $y$, Kulung has $g$ and Eastern 
Kiranti again shows $y$, as summarised in Table 2. In contrast to van Driem (2001), Opgenort (2005) does not discuss the sound correspondence where Eastern Kiranti shows unexpected $r$ instead of regular $y$.

\begin{tabular}{lllll} 
TABLE 2 & \multicolumn{5}{l}{ Rhotics in Opgenort $(2005: 13,34-36)$} & \\
\hline Proto-Kiranti & Western & Central & Kulung & Eastern \\
& & & & \\
${ }^{*} r$ & $r$ & $r$ & $r$ & $y$ \\
${ }^{*} r y$ & $r \sim y$ & $r \sim y$ & $g$ & $y$
\end{tabular}

An elaborated account on the rhotics is provided by Opgenort (2011: 262-263). While the distinction between ${ }^{*} r$ and $* r y$ is maintained, a further proto-phoneme, a 'dorsal' *' $r$, is introduced to explain the different sound correspondences found in the lexemes for 'stand' and 'body', the former showing Hayu, Jero, Wambule and Thulung $y$ :Western $r$ : Central (including Kulung) $r$ : Eastern $y$ and reflecting Proto-Kiranti * $r y$, the latter evincing Western and Central $r \sim y$ : Kulung $g$ : Eastern $y$ and reflecting Proto-Kiranti * $r$ (Opgenort 2011: 262-263). Here, the two irregularities which were treated together in Opgenort (2005) are split, whereby Kulung $g$ is explained by assuming a second rhotic sound * $r$ and the irregular reflexes $y$ in Western and Central are explained by both the assumption of a proto-cluster *ry and the second rhotic * $r$. This therefore constitutes an approximation to the reconstruction of van Driem (2001: 618), with the new element *ry. This analysis is shown in Table 3.

TABLE 3 Rhotics in Opgenort (2011: 262-263)

\begin{tabular}{lllll}
\hline Proto-Kiranti & Western & Central & Kulung & Eastern \\
\hline${ }^{*} r$ & $r$ & $r$ & $r$ & $y$ \\
${ }^{*} r y$ & $r \sim y$ & $r$ & $r$ & $y$ \\
${ }^{*} r$ & $r \sim y$ & $r \sim y$ & $g$ & $y$ \\
\hline
\end{tabular}

The issue of rhotics and their reflexes in the different Kiranti groups is not conclusively clarified, and conditioning environments, analogy and borrowing of individual lexemes may further blur the picture. The reconstruction of three different rhotic sounds as proposed by Opgenort (2011) therefore seems exaggerated and at the same time cannot regularise the attested sound correspondences completely. The possibility of borrowing and conditioning environments for the lenition of ${ }^{*} r$ to $y$ in non-Eastern languages is considered by Jacques (2017: 195), who explains the existence of $y$ or zero as reflexes of ${ }^{*} r$ in Wambule and Bantawa, respectively, as conditioned by following front vowels and aberrant instances as potential borrowings. Jacques (2017: 195) also briefly mentions the alternative possibility of reconstructing two different rhotics for Proto-Kiranti and attributes this thought to Bickel/Gaenszle (2015) and Opgenort (2005), although it has already been introducted by van Driem (2001: 618).

Proto-Kiranti * $k w>$ Proto-Western Kiranti * $? w$ An important phonological topic discussed by Opgenort $(2004 \mathrm{~b})$ is the potential innovation from Proto Kiranti ${ }^{*} k w$ to Proto-Western Kiranti ${ }^{*} w$, which was first observed by Michailovsky (1994). The starting point of Opgenort (2004b) is Wambule. He shows that the implosive stops $b$ and $d$ of Wambule derive from two different sources, first from Proto-Kiranti preglottalised nasals $* ? m$ and $* ? n$, which were merged elsewhere in Kiranti and solely retained in Wambule in 
the form of implosives, and second from the Proto-Kiranti cluster * $k w$, which, in his account, developed into ${ }^{*} ? w$ in Proto-Western Kiranti and can therefore be viewed as a shared defining innovation for Western Kiranti languages. The evidence by Opgenort (2004b) for the reconstruction of * $? w$ to ProtoWestern Kiranti comes from Wambule, Sunwar and Bahing, which show implosives or preglottalised voiced stops (cf. Michailovsky 1994), whereas the other Western Kiranti languages Jero, Hayu, Khaling, Dumi and Kohi do not regularly share this innovation. Therefore, it is a stretch to speak of a Western Kiranti innovation. Rather, the data suggest that Wambule, Bahing and Sunwar constitute a subgroup on the basis of the shared innovation of * $k w>? w$.

Opgenort (2004b: $5^{-8}$ ) presents eleven lexemes where Western Kiranti languages allegedly show reflexes of Proto-Western Kiranti ${ }^{*} ? w$, supplemented with Eastern Kiranti reflexes and some ProtoKiranti reconstructions from the online publications of Sergei Starostin ${ }^{13}$ as well as external comparanda, namely Chepang and Magar and at times Proto-Tibeto-Burman, the latter taken from Matisoff (2003). In addition to the small number of examples, many of them are unconvincing and do not support the reconstruction of $* w$ to the alleged common ancestor of all Western Kiranti languages or of * $k w$ for Proto-Kiranti. In the following, the eleven lexemes of Opgenort (2004b) are discussed. The full list is shown in Table 4, employing the transcription of Opgenort and of the data sources he cites.

Only the first five lexemes, i.e. 'wound', 'shadow', 'fishing trap', 'eat, gnaw' and 'chicken' qualify as instances of the proposed sound correspondences. For the sixth lexeme, 'water', Wambule actually shows initial $k$ instead of $b$ and this lexeme must therefore be dismissed as evidence for Proto-Western Kiranti *?w. Furthermore, Dumi and Khaling also show initial $k$, not reflecting the alleged Proto-Western Kiranti innovation $* k w>? w$, and non-Western Kiranti languages show initial $w$ instead of expected $k w$, so that the Proto-Kiranti initial may also have been $w$. The Wambule, Khaling and Dumi forms with initial $k$ may reflect an etymologically distinct root. Lexemes 7-11 show a bilabial stop not only in Western, but also in Eastern Kiranti languages, so the proposed regular sound correspondence Western $? w$ : Eastern $k w$ does not apply. Thus, there is no reason to reconstruct * $k w$ for Proto-Kiranti and ${ }^{*} ? w$ for Proto-Western Kiranti for these lexemes.

The remaining lexemes 1-5 are unconvincing, although they show the expected sound correspondence. For the first lexeme, 'wound', it is only Wambule, Bahing, Hayu and Thulung which show an initial bilabial stop, either implosive, voiced or voiceless. The other Western Kiranti languages, namely Sunwar, Khaling and Dumi, show initial $k h w$ and $k$, respectively. This correpondence, therefore, does not provide evidence for a common Western Kiranti innovation * $k w>* ? w$. For the second and third lexemes, 'shadow' and 'fishing trap', Wambule, Bahing and, in the case of 'shadow', Thulung are the only languages to show reflexes of the etyma, so that it remains unclear whether ${ }^{*} k w$ or ${ }^{*} p \sim b$ should be reconstructed to ProtoKiranti. Chepang shows $k w$ in both instances, but this is no evidence for Proto-Kiranti *kw. The fourth lexeme, 'eat, gnaw', shows a bilabial stop in Wambule, Sunwar, Bahing and Thulung and, in Opgenort's account, also in Khaling. In Jacques (2017: 193), however, the same Khaling verb root has initial $k$. Therefore, either the innovation is again restricted to a subgroup of Western and does not pertain to all Western Kiranti languages, or there is no evidence to assert whether Proto-Kiranti had ${ }^{*} k w$ or ${ }^{*} p \sim b$, since no Eastern Kiranti cognates are given. Finally, the fifth lexeme, 'chicken', shows a bilabial initial in

13 The URL given by Opgenort (2004b: 27) for Starostin's materials is no longer accessible, but Starostin's Proto-Kiranti reconstructions can still be found on the webpage of the 'Tower of Babel' etymological database project (http://starling. rinet.ru/). 


\begin{tabular}{|c|c|c|c|c|c|c|c|c|}
\hline No & Meaning & Wambule & Sunwar & Bahing & Hayu & Thulun & g Others & External \\
\hline 1 & 'wound' & bari & $g \bar{a} r$ & bar & bu?ma & par & $\begin{array}{l}\text { Khaling 'kwaar, } \\
\text { Kulung kher }\end{array}$ & $\begin{array}{l}\text { Kham 'khxtera, } \\
\text { Chepang khay }\end{array}$ \\
\hline 2 & 'shadow' & bala & - & bala & - & pel & - & Chepang kwa.lay? \\
\hline 3 & 'fishing trap' & ballu & - & ba:luy & - & - & - & Chepang kwalh \\
\hline 4 & 'eat, gnaw' & bacam & $\left({ }^{\prime}\right) b w a(w)-$ & $P b a(t)-$ & - & $p(e)^{-}$ & Khaling bat- & Kham kxya- \\
\hline 5 & ‘chicken’ & $6 o$ & $b w \bar{a}$ & $6 a$ & xo:co & $-w a, p o$ & $\begin{array}{l}\text { Khaling phö, Bantawa } \\
w a, \text { Limbu wa? }\end{array}$ & $\begin{array}{l}\text { Magar } g w \bar{a}, \\
\text { Chepang } w a ?, \text { Ртв } \\
\text { *wa }\end{array}$ \\
\hline 6 & 'water' & ka:ku & bwaakku & bo:ky & - & $w a-$ & $\begin{array}{l}\text { Khaling } k u \text {, Dumi } k \dot{t} \\
\text { Kulung } k a w a, \text { Limbu } w a-\end{array}$ & - \\
\hline 7 & 'throw' & barcam & $(?) \operatorname{war}(d)-$ & ward- & - & par- & $\begin{array}{l}\text { Khaling 'waan-nä, } \\
\text { Kulung bu:ma, Limbu } \\
\text { phe:ma, Proto-Kiranti } \\
{ }^{*} b(h) \ddot{a r} \sim{ }^{*} ? p \ddot{a} r\end{array}$ & Chepang war $(h)$ - \\
\hline 8 & 'cheek' & bambu & - & - & - & phosü & $\begin{array}{l}\text { Khaling phosu, Dumi } \\
\text { busu, Kulung phousi, } \\
\text { Proto-Kiranti *phòsu }\end{array}$ & - \\
\hline 9 & 'mix, stir' & bwalcam & - & - & - & phol- & $\begin{array}{l}\text { Khaling phwaal-nä, } \\
\text { Kulung phelma, Limbu } \\
\text { phupma?, Proto- } \\
\text { Kiranti *phòl }\end{array}$ & Kham bxre:- \\
\hline 10 & 'scratch' & bapcam & bam-si-ca & - & - & phrap- & $\begin{array}{l}\text { Khaling präm-nä, } \\
\text { Bantawa pāmma, } \\
\text { Kulung pamma, } \\
\text { Proto-Kiranti *phräp }\end{array}$ & $\begin{array}{l}\text { Kham 'bxram-, } \\
\text { Ртв *pruk }\end{array}$ \\
\hline 11 & 'shoulder' & basyam & balā & - & - & 'balam & $\begin{array}{l}\text { Khaling 'bhaataa, } \\
\text { Dumi bokto, Kulung } \\
\text { bouto, Athpahariya } \\
\text { phaktay, Limbu } \\
\text { pho:ktay, Proto-Kiranti } \\
\text { *bhák Ppák }\end{array}$ & $\begin{array}{l}\text { Kham 'pon, } \\
\text { Chepang bal.(na) }\end{array}$ \\
\hline
\end{tabular}

Wambule, Sunwar, Bahing, Thulung as well as Khaling and Dumi, but Hayu shows $x(\sim k h \sim k h w)$, and other Kiranti languages show initial $w$. Therefore, again, the sound change is not shared by all Western Kiranti languages. Additionally, the original initial here may have been $w$ instead of $k w$, as suggested by the external cognates. Furthermore, this lexeme may be onomatopoetic, and initial $k, w$ or $k w$ are to be expected in expressive names for chicken.

Jacques (2017: 193) also briefly discusses this sound correspondence without providing new evidence for a shared innovation of all Western Kiranti languages. In his account, which includes only four 
languages, namely Wambule, Khaling, Bantawa and Limbu, Proto-Kiranti * $? w$ first became * $k w$ and later merged with * $k$ in Khaling, Bantawa and Limbu, whereas in Wambule, the cluster was retained and became a bilabial implosive (cf. Jacques 2017: 193). This analysis implies that the implosive in Wambule is a specific innovation of this language and not a defining shared innovation of Western Kiranti. ${ }^{14}$

In sum, there is no convincing empirical evidence to assume that all Western Kiranti languages share the sound change ${ }^{*} k w>? w$. At most, this could be defined as a shared innovation of Wambule, Bahing and Sunwar. ${ }^{15}$ For Thulung, it seems uneconomic to assume the intermediate stage ${ }^{*} w$ to explain the development $* w>p$ evinced in a number of lexemes. In the following, we turn to the lexical and morphological evidence brought forward by Opgenort $(2005,2011,2014)$ in favour of his Kiranti subgrouping.

Lexical isoglosses Opgenort $(2005,2011,2014)$ presents lexical isoglosses to argue for the coherence of Kiranti and for his internal classification of Kiranti languages. The data used by Opgenort changed slightly over time, and it is useful to first give a short outline of his data. Opgenort $(2005: 6,40)$ provides fourteen lexical isoglosses for the thirteen Kiranti languages compared in this publication, namely Jero, Wambule, Bahing, Sunwar, Hayu, Khaling, Dumi, Thulung, Chamling, Bantawa, Kulung, Yamphu and Limbu. In Opgenort (2011: 266-268), twelve lexical isoglosses are presented, with considerable divergence from the list of 2005. To the list of thirteen languages of Opgenort (2005), Tilung is added in Opgenort (2011: 266-268). In Opgenort (2014), finally, fourteen lexical isoglosses are given, the same as 2011 with two additional entries, both of which already appeared in the 2005 list. Opgenort (2014) does not provide the reason for the differences in the selection of his lexical isoglosses.

Opgenort (2011: 269) asserts that Western Kiranti is lexically more innovative than Eastern Kiranti and can be defined on the basis of shared lexical isoglosses. However, many of the 2011-2014 isoglosses are rather messy and contradictory in that they do not bundle neatly, some involving Eastern and Western Kiranti languages, namely 'arm', 'black', 'dog', 'earth', 'egg', 'hair', 'head', 'hear', 'lie down', 'one'. Conceivably, a significant number of lexical items have been borrowed across different Kiranti languages. If contact is excluded as an explicatory factor for the distribution of the individual etyma, a very confusing classification of Kiranti languages would be the result. However, if contact is taken into account, many isoglosses become valueless for an internal classification of Kiranti. The Western-Eastern distribution of certain lexemes, e.g. 'axe', 'black', 'do, make' or 'give', may then represent areal spreading of certain etyma rather than shared innovations. Opgenort (2011) himself repeatedly acknowledges contact as an important factor in the distribution of different lexical roots, e.g. to explain the lexical aberrancy of the Western Kiranti languages Dumi, Khaling or Tilung, which he calls 'marginal members of Western Kiranti' (Opgenort 2011: 267, 269) since they are Western Kiranti languages with regard to the sound correspondences, but are closer to Eastern than to Western Kiranti lexically. Generally, lexical evidence for subgrouping is problematic if intensive contact can be assumed for the area in question, which is the case for the Kirãt. The lexical isoglosses of Opgenort are not conclusive evidence for a stable internal classification beyond

14 However, it must be kept in mind that Jacques (2017) only includes two Western Kiranti languages in his comparison, of which one, Khaling, also regularly shows an aberrant reflex in the comparison of Opgenort (2004b).

15 Potentially, Hayu and Jero can also be included, since Hayu shows the expected reflex for the lexeme 'wound', but an unexpected or no reflex for all others, and since Jero, despite showing an ambiguous reflex $m$ (cf. Opgenort 2004b), is undoubtedly more closely related to Wambule than Sunwar or Bahing. 
the basic Western-Eastern dichotomy. The alleged shared lexical innovations of Western Kiranti may represent areally spread roots.

Morphological comparison of Western Kiranti Opgenort (2005: 43-49) further undertakes a morphological analysis of Western Kiranti languages, namely for the domains of personal and possessive pronouns, case morphology and intransitive verb agreement morphology. The languages considered are Jero, Wambule, Bahing, Sunwar, Hayu, Thulung, Khaling and Dumi. The findings of his investigation show that certain Western Kiranti languages, namely Jero and Wambule, Bahing and Sunwar or Khaling and Dumi seem to be more closely related, although Opgenort (2005: 43-49) does not work out explicit shared morphological innovations for any subgroup nor for Western Kiranti in general. Consequently, these groups remain impressionistic hypotheses rather than empirically verified facts, and the possibility of morphological borrowing or calques should be considered in future research. Furthermore, Western Kiranti has not been proven to constitute a monophyletic subgroup on the basis of this morphological evidence.

Summary The historical-comparative work by Opgenort (2004b, 2005, 2011, 2014) constitutes an important contribution, but his argumentation cannot provide evidence for a classification of Kiranti that goes beyond the basic Western-Eastern split. His morphological examination does not provide shared morphological innovations for Western Kiranti, neither does the lexical comparison provide conclusive evidence for this subgroup, although it indicates a potential closer relationship between individual Western Kiranti languages. Finally, his phonological comparison supports the findings of Michailovsky (1994) and van Driem (1990b, 2001), but the assumption of a shared Western Kiranti innovation * $k w>{ }^{*} ? w$ is not supported by empirical evidence.

\subsection{The Steep Tree of Bickel/Gaenszle (2015)}

Bickel/Gaenszle (2015: 75-76) present evidence for a steep Kiranti family tree, cf. Table 5 . Their classification maintains the primary distinction between a Western and an Eastern branch established by Michailovsky (1994) and adds an intermediate Midwestern branch. The Eastern branch sensu Michailovsky (1994), called 'Central-Eastern' by Bickel/Gaenszle (2015), is divided into a Central and Greater-Eastern branch, the latter showing two branches, Upper Arun and Eastern. Eastern is further split into Greater Yakkha and Limbu. Midwestern consists of Thulung and Kohi and Western is divided into three subgroups, Chaurasiya, Northwestern and Upper Dudhkosi, which correspond to the eponymous subgroups by van Driem (2001: 615). The structure of the family tree is motivated by sound laws (cf. Bickel/Gaenszle 2015: 75), except for the groups Greater Yakkha, Northwestern and Upper Dudhkosi, for which no defining sound laws are given. However, several of the assumed sound changes are not diagnostic for the subgroups for which they are presented as defining shared innovations and thus make the family tree of Bickel/Gaenszle (2015) erroneous. These sound changes are discussed in the following. ${ }^{16}$

16 Data for the following discussion are taken from the following sources: van Driem (1987) for Limbu, Bickel/Gaenszle (2015) for Chintang, Ebert (1997a) for Athpahariya, van Driem (n.d.(a)) for Lohorung, Tolsma (2006) for Kulung, Doornenbal (2009) for Bantawa, Opgenort (2004a) for Wambule, van Driem (1993a) for Dumi, Rutgers (1998) for Yamphu, Lahaussois ( 2002) for Thulung and Schackow (2015) for Yakkha. Mewahang and Nachiring data as well as some Lohorung data are our own. 


\section{Subgrouping}

Central-Eastern

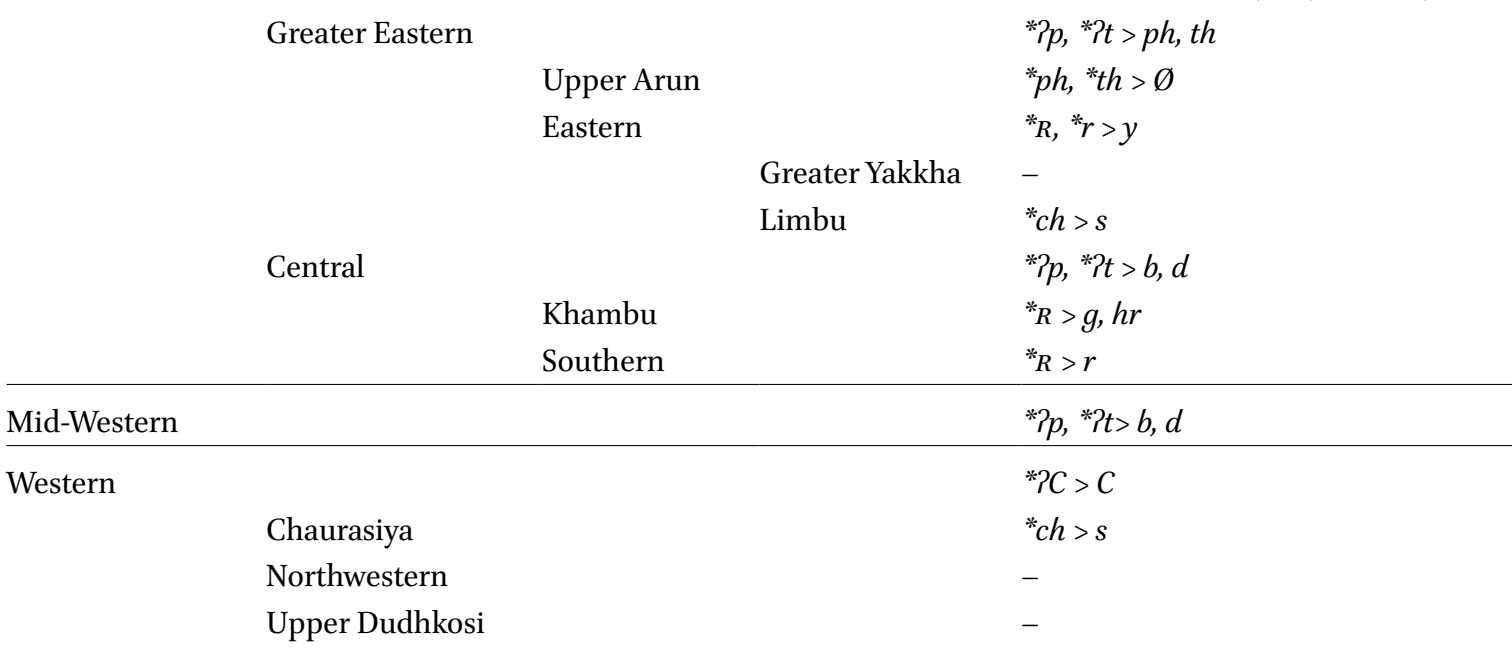

\section{Shared innovations}

*voiced > voiceless, ${ }^{*}$ ?k, *?c $>$ kh, ch . 
this is not the case in Lohorung or Mewahang, cf. Table 7. The evidence from Mewahang and Lohorung shows first that the segments are not lost in Upper Arun, and second that the reflexes are not voiceless aspirated, but voiced stops.

TABLE $7 \quad$ Outcomes of * $? p$ and $* 2 t$ in Upper Arun

\begin{tabular}{|c|c|c|c|c|}
\hline Gloss & Mewahang & Lohorung & Yamphu & Western \\
\hline 'pig' & bak & bak & $a k m a$ & Wambule $p a$ \\
\hline 'flower' & buywa & buy & $u \eta$ & Dumi puma \\
\hline 'to beat' & dupma & duPma & ирта & Wambule tupcam \\
\hline 'to drink' & duүma & duүma & uүma & Wambule tuicam \\
\hline
\end{tabular}

The loss of these segments in Yamphu, but the retention as voiced stops in the closely related languages Lohorung and Mewahang implies that the segments were still present in Proto-Upper-Arun, potentially as preglottalised voiced stops or implosives and that their loss represents a specific development of Yamphu. ${ }^{18}$

The sound change of * $P p$ and * $? t$ to Upper Arun $p h$ and th assumed by Bickel/Gaenszle (2015) is also unconvincing since the development of *?p and * $? t$ to $p h$ and $t h$ merged these sounds with the primary * $p h$ and $*$ th. The subsequent loss of * $p h$ and *th, however, obviously only affected the secondary aspirates, deriving from original preglottalised stops, since aspirated bilabial and dental stops with cognates outside the Upper Arun group are attested for Yamphu, Mewahang and Lohorung, e.g. Yamphu phip-, Mewahang phi:p- 'to suck' : Nachiring phip-, Thulung phim-, Yamphu phi:k- 'to sweep' : Dumi phitk-, or Yamphu thak- 'to weigh' : Kulung tha- thok- ... The assumption of Bickel/Gaenszle (2015) therefore constitutes an anachronistic interpretation of the data.

Development of ${ }^{*} r$ in Greater Eastern Another erroneous assignment of a sound change is the confinement of the lenition of the rhotic sounds of Proto-Kiranti to a palatal glide to Eastern Kiranti, i.e. Greater Yakkha and Limbu, excluding the Upper Arun languages. However, these latter languages also show reflexes of the same lenition, cf. Table 8, as pointed out earlier by Shafer (1953: 361) or van Driem (199ob).

\begin{tabular}{|c|c|c|c|c|}
\hline Gloss & Mewahang & Lohorung & Yamphu & Comparanda \\
\hline 'salt' & yum & yum & yum & Dumi rim, Nachiring rum \\
\hline 'to stand' & yepma & ye?ma & ye:pma & Dumi repni, Nachiring rem \\
\hline 'body' & - & yam & yami 'body hair' & Dumi ram, Nachiring ram \\
\hline 'to laugh' & yu:ma & yicama & yi:tcama & Dumi ri:ni, Nachiring rim \\
\hline
\end{tabular}

18 In fact, voiced bilabial and dental stops in Mewahang, for example in bak 'pig', leave the acoustic impression of implosive segments, but this needs to be investigated in more detail in future research. Another piece of evidence for an intermediate implosive or preglottalised voiced stage in Upper Arun is that $* p$ and $* t$ are retained as a glottal stop in word-internal position in Yamphu, e.g. Yamphu ri-?um 'four-CLAss' : Mewahang lik-bom, Yamphu samba-?uך 'rose' : Mewahang buywa 'flower', Yamphu wariy 'egg' : Mewahang wadin. 
Lenition of ${ }^{*} c h>s$ The sound change ${ }^{*} c h\left[\mathrm{t}^{\mathrm{h}} \sim \mathrm{ts}^{\mathrm{h}}\right]>s$ is confined in the classification by Bickel/ Gaenszle (2015) to Limbu and given as a defining innovation of Limbu alone. However, the sound change is also attested in the Upper Arun languages Yamphu (cf. Opgenort 2005: 13) and Lohorung, cf. Table 9. Parallel lenitions of ${ }^{*} c h>s$ are also attested in Western Kiranti languages, e.g. Chaurasiya or Bahing (cf. Opgenort 2005:13; Bickel/Gaenszle 2015:76), where they certainly represent independent developments. This sound change therefore seems quite natural and frequent in Kiranti and is of little diagnostic value for the definition of a subgroup. Consequently, no defining innovation of Limbu or Chaurasiya remains in Bickel/Gaenszle (2015: 76), and the languages cannot be separated from the Greater Yakkha group and the other Western groups, respectively.

TABLE 9 Development of * $c h$ in Eastern Kiranti

\begin{tabular}{llll}
\hline Gloss & Limbu & Upper Arun & Comparanda \\
\hline 'song' & samlo: & Lohorung sa:m, Yamphu semluma & Kulung cham, Yakkha chem \\
'to dance' & - & Yamphu simmama & Thulung tshwmmu, Dumi tsəmni \\
'to close' & sakma? & Lohorung sekma, Yamphu scekma & Thulung tsomu, Kulung chima \\
'mouse' & suba & Yamphu si?numa & Wambule cicimo, Kulung chuwi \\
& & & \\
\hline
\end{tabular}

Merger of rhotics in Southern Kiranti The identification of the merger of ${ }^{*} R$ with ${ }^{*} r$ as a shared, defining innovation of Southern Kiranti by Bickel/Gaenszle (2015: 76) is problematic, since the same change also happened in other Kiranti languages, e.g. Sunwar, Thulung, Khaling, Dumi or Tilung (cf. Opgenort 2011: 262) and Nachiring as well as the Eastern languages which merged the two rhotics before the lenition to $y$. The development may thus constitute a shared innovation on a higher level or a series of parallel, independent innovations and cannot conclusively be identified as a shared innovation of the Southern Kiranti languages.

Other problematic assumptions in the family tree by Bickel/Gaenszle (2015) attributable to the erroneous analysis of previous research by Driem (2001) or Opgenort $(2005,2011,2014)$ are not discussed here, since they have already been pointed out in the preceding $\S 2.3$ and 2.4. This concerns the alleged shared innovation of preglottalised stops to plain voiceless stops in Western Kiranti and of the development ${ }^{*} R$ $>g, h r$ in Khambu. Therefore, these two changes are not defining shared innovations for Western Kiranti and Khambu, as assumed by Bickel/Gaenszle (2015: 76). Finally, it is questionable why the same innovation, namely the development ${ }^{*} p,{ }^{*} ? t>b$, $d$, is used by Bickel/Gaenszle (2015) as a shared innovation of two different subgroups, namely Midwestern and Central. A more economic assumption would be to view this development as a shared innovation of a subgroup involving both Central and Midwestern (see $\S$ 2.6). A valuable aspect of the classification of Bickel/Gaenszle (2015) is the inclusion of Chintang in Greater Yakkha. This constitutes an improvement with regard to the previous classification of Chintang into the Southern group (cf. van Driem 2001: 615), since the reflexes of the preglottalised bilabial and dental stops in Chintang are voiceless aspirated stops, as in Athpahariya, Belhare, Yakkha and Limbu and unlike Central, Southern and Upper Arun, which show voiced stops. ${ }^{19}$

19 Chintang also shares a morphological innovation not mentioned by Bickel/Gaenszle (2015) with the Greater Yakkha languages Athpahariya, Belhare and Yakkha, namely the exclusive marker $-\eta(a)$ ( see $\S$ 3.2.3). 


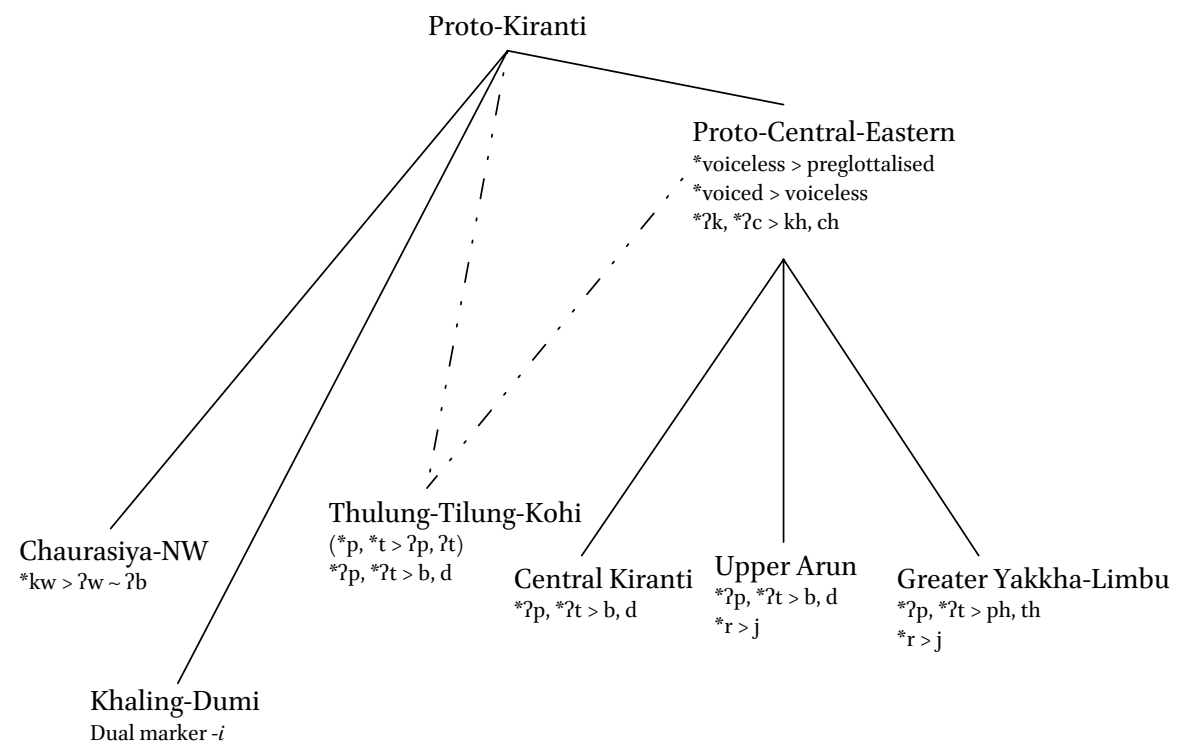

FIGURE 2 Summary of current knowledge about the phylogeny of Kiranti

\subsection{Discussion}

The present state of the internal classification of Kiranti based on strict historical-comparative methodology allows for the identification of a coherent subgroup involving the languages commonly referred to as Eastern or non-Western Kiranti sensu Michailovsky (1994). The remaining ('Western') Kiranti languages do not form a coherent subgroup due to lack of evident shared innovations, i.e. they form a residue group. In the following, we will refer to the Eastern or non-Western group as 'Central-Eastern'. Within Central-Eastern, phonological developments allow for the identification of three subgroups, namely Central, Upper Arun and Greater Yakkha-Limbu.

The shared phonological innovation of the Central-Eastern group is the preglottalisation of voiceless stops, the devoicing of voiced stops and the aspiration of preglottalised velar and palatal obstruents (cf. Figure 2). The further branching of the Central-Eastern group is not straightforward. The reason for this is the existence of shared phonological innovations both between Central and Upper Arun, excluding Greater Yakkha-Limbu, and between Upper Arun and Greater Yakkha-Limbu, excluding Central. The shared innovation of Central and Upper Arun is * $? p$, * $? t>b, d$, while Upper Arun and Greater YakkhaLimbu share ${ }^{*} r>y[\mathrm{j}]$.

The classification of Central-Eastern thus depends on the relative chronology of subsequent sound changes and the differentiation of genetically shared innovations, areally spread innovations and parallel independent innovations that one has to assume in classifying these languages. Two classifications are possible. Either solution results in a somewhat inelegant and complicated classification, since isoglosses are not consistent and each possibility therefore needs to build areal spreading or parallel independent innovations into the scheme. With regard to typological plausibility of the sound changes, there is no clear preference for either classification, since both sound changes ${ }^{*} p p$, ${ }^{*} t t>b, d$ and ${ }^{*} r>y$ are considered similarly natural, the preglottalisation of voiceless plosives leaving an implosive, i.e. voiced, acoustic impression, while the general instability of rhotic liquids can easily lead to a lenition to a palatal glide.

The first classification groups the Upper Arun languages together with Central Kiranti on the basis of the shared phonological innovation of voicing and deglottalisation of the preglottalised stops and regards 
the shared phonological trait between Upper Arun and Greater Yakkha-Limbu, i.e. lenition of ${ }^{*} r$ to a palatal glide, as an areally spread feature not significant for subgrouping.

The second classification groups Upper Arun and the Greater Yakkha-Limbu together on the basis of the change ${ }^{*} r>y$. In this scheme, the preglottalised stops only later developed in different ways in Upper Arun and Greater Yakkha-Limbu, namely to voiced stops or zero in Upper Arun and to aspirated voiceless stops in Greater Yakkha-Limbu. This scheme also necessarily implies that the shared development of the preglottalised stops in Upper Arun and Central Kiranti is either an areal feature or an independent parallel innovation.

The case of Thulung, Tilung and Kohi is instructive in strongly suggesting the possibility of either independent phonological developments or of areally spread sound changes in the Kiranti area. These three languages show the same outcome as Central and Upper Arun for the bilabial and dental preglottalised stops, namely voiced stops (cf. Michailovsky 1994; Opgenort 2011: 26o-261; Lahaussois 2009:1), but do not share the defining developments *voiced $>$ voiceless and ${ }^{*} ? k,{ }^{*} ? c>k h$, ch of Central-Eastern Kiranti.

To account for the phonological developments, there are two possible solutions. The first analysis assumes a subgroup including the Central-Eastern languages as well as Thulung-Tilung-Kohi, defined by the glottalisation of Proto-Kiranti ${ }^{*} p$ and ${ }^{*} t$. Subsequently, Thulung-Tilung-Kohi split off from this group and deglottalised ${ }^{*} p p$ and ${ }^{*} p t$ to $b$ and $d \sim q$. The remaining Central and Eastern Kiranti languages are then defined as a coherent subgroup by the developments ${ }^{*} k,{ }^{*} c>? k, ? c>k h$, ch and ${ }^{*}$ voiced $>$ voiceless, and then further differentiated as pointed out above. However, from the inclusion of Thulung, Tilung and Kohi into Central-Eastern, it follows that Thulung-Tilung-Kohi and Central-Upper Arun underwent the development of ${ }^{*} ? p$ and ${ }^{*} ? t>b$ and $d$ independently and that the Central-Eastern languages divided the glottalisation of the inherited voiceless stops in two stages, first affecting the bilabial and dental stop, a sound change shared with Thulung-Tilung-Kohi, and then the velar and palatal obstruents only after Thulung-Tilung-Kohi split off from the group. This analysis involves a considerable amount of independent parallel innovations and is thus not very elegant.

However, the second analysis is similarly inelegant. If Thulung-Tilung-Kohi are not assigned to a common subgroup with Central-Eastern Kiranti and even if a separate series of preglottalised stops is reconstructed to Proto-Kiranti, Thulung, Tilung and Kohi would still exhibit a shared sound change with Central Kiranti and Upper Arun, namely the development of preglottalised bilabial and dental stops to voiced stops. This identical development must necessarily be classified as a parallel, independent change and cannot be a defining shared innovation.

This corroborates the assumption that at least a part of the shared sound changes in Kiranti languages must be areally spread features or parallel innovations instead of diagnostic evidence for closer genetic relationship. At the present stage and considering the significant amount of exceptions and irregular reflexes in various branches and languages (cf. also Opgenort 2005, 2011), ${ }^{20}$ a definite classification of Central-Eastern is still a desideratum of future research.

The state of the art of Kiranti internal classification is recapitulated in Figure 2. Whereas the CentralEastern languages can be traced back to an intermediate common ancestor, the Western Kiranti languages, i.e. Chaurasiya-Northwestern, Khaling-Dumi and Thulung-Tilung-Kohi, do not form a single node in the family tree and therefore constitute a polyphyletic group whose most recent common genetic ancestor is (at least) Proto-Kiranti (cf. section 3). Figure 2 is agnostic with regard to the further classification of the Central-Eastern group, since phonological isoglosses do not coincide, as discussed above.

20 Cf. Jacques (2017: 191-193) for the possibility of a conditioning of certain irregular correspondences by the fusion of the onset with former prefixes. 
The different Western Kiranti languages, although not forming a single subgroup, can be assigned to different intermediate subgroups, one of which is the Chaurasiya-Northwestern subgroup, consisting of Wambule, Bahing, Sunwar and probably also Jero and Hayu on the basis of the shared sound change ${ }^{*} k w>? w \sim ? b$ (cf. $\left.\S 2.2,2.4\right)$. Another subgroup may consist of Dumi and Khaling, which share an innovative verbal dual marker $-i$ (cf. $\S$ 3.2.3, Table 15). Kohi, Thulung and Tilung are grouped together on the basis of the shared sound change of ${ }^{*} p$ and ${ }^{*} t$ to $b$ and $d$, probably via an intermediate stage with preglottalised voiceless stops. Since this is a sound change which these languages share with the Central-Eastern languages, but with unclear relative chronology, as discussed above, the classification of Thulung-TilungKohi within Kiranti is ambiguous.

The evidence put forward for a monophyletic Kiranti branch of Trans-Himalayan consists of a bundle of non-linguistic and linguistic arguments. For a linguistic classification, only linguistic arguments are valid. Non-linguistic arguments may be important to understand the history of research on Kiranti languages, to understand the ethno-historical classification of the Kiranti people or to provide additional evidence for or against a linguistic classification, but should not be treated as primary evidence for the classification of the languages in question. We will first present two non-linguistic arguments which, in our opinion, explain the persistence of the view that the Kiranti languages should form a coherent subgroup, and will then turn to linguistic arguments.

\subsection{Non-Linguistic Arguments}

The non-linguistic arguments for a coherent Kiranti branch are the adherence to certain research traditions and ethnological arguments. We will discuss these two arguments in turn.

The definition and extent of Kiranti has changed over time. However, the paradigm shifts did not come about by critical assessment of the linguistic evidence for the previous classification, but rather by replacement of one more or less unsubstantiated scholarly intuition by another one (see $\S 2.1$ ). The definitions of Kiranti by Konow (Grierson 1909), Shafer (1953), Hanßon (1991) and van Driem (2001) appear to be based on a number of different factors, only some of which are linguistic in nature, others being cultural, ethnic, religious, geographical, political or historical factors. The linguistic factors often are superficial similarities and typological parallels instead of shared innovations, a tradition that started with Konow's 'Eastern group' of pronominalised languages, i.e. languages assumed to be more closely related to each other because they share the typological feature of verb agreement, without investigating the morphology itself. The changing definition of Kiranti over time (see $\S 2.1$ ) was never based on firm empirical grounds, and the reproduction of and adherence to these classifications in subsequent publications constitutes the rendering of a received scholarly opinion rather than an empirically well-founded theory.

A second non-linguistic argument for the identification of Kiranti as a linguistic subgroup is the ethnological and historical background of the Kiranti peoples. These peoples are generally classified under the single ethnolinguistic label Kiranti, even though eastern Nepal is characterised by a distinct cultural and linguistic heterogeneity. The Kiranti peoples consist of different ethnic groups, namely the Sunwar, Rai, Yakkha and Limbu. Even the cover term Rai, which is used for all Kiranti peoples except the Limbu, Yakkha and Sunwar, is perceived as an inadequate and sometimes even oppressive label by speakers of individual Rai languages, since it blinds out the linguistic and cultural diversity exhibited among the 
different Rai communities. The equation of all these different ethnolinguistic and cultural groups with the single exonymous cover term Kiranti is unjustified and transports the wrong impression that all the languages spoken by this alleged homogeneous Kiranti people must be closely related, too.

Additionally, as will be mentioned in section 5 , the ethno-historical self-perception of certain Kiranti communities kept alive in mythological narration goes beyond the artificial construct Kiranti and includes other ethnic groups not normally brought into relationship with Kiranti (cf. Ebert/Gaenszle 2008: 11-13).

Generally, the equation of ethnic and linguistic identity is not always straightforward and ethnic relationship is no argument for linguistic relationship without linguistic evidence supporting the equation. Examples of the mismatch between cultural and linguistic identity are abundant around the globe. Even where matches occur, ethnological arguments cannot replace linguistic arguments in the establishment of a linguistic subgroup.

Furthermore, the two cover terms Kiranti and Rai both are rather recent designations and no old autonyms. The Sanskrit term Kirāta, to which Kiranti may be related, was used in Sanskrit literature to refer to hill people or 'hunters' in general, and Kiranti was not used as a self-designation before the conquest of the Kirãt by the Gorkha Kings in the 18th century (cf. Gaenszle 2002: 339), although it was used as a purely geographical and administrative exonym before this time (cf. van Driem 2001: 596). ${ }^{21}$ With regard to the term Rai, Gaenszle (1991: 3) explains that it was originally a kind of administrative title given to certain chieftains of Eastern Nepal at most a few centuries ago and only later became an ethnonym and a common self-designation, probably in the course of the 19th century. The term Rai is not used in the publications of Hodgson (cf. Gaenszle 1991: 11), which indicates that the designation only spread afterwards, i.e. in the second half of the 19th century, as an ethnonym.

Before Kiranti and Rai, the term Khambu seems to have prevailed among the Rai people (cf. Gaenszle 2002: 339), and this term is also used as a cover term in Grierson (1909). This name may be related to Tibetan Khampa, as thought by Hodgson (1858: 449), who assumed an origin of the Kiranti people in Kham, i.e. Eastern Tibet. Alternatively, the term may, again, be an inclusive exonym which identified the different groups in the Kirãt with other Tibeto-Burman groups of the region, notably Tibetan. In this context, it is also noteworthy that different Kiranti groups claim two genetic lineages (gotra) for themselves, a southern plane lineage from Benares and a lineage going back to Lhasa in Tibet (cf. Gaenszle 1991: 126-127; van Driem 2001: 673-674). Likewise, the Sunwar have intermarried with neighbouring Sherpas (cf. van Driem 2001: 725-726). These relations of intermarriage and the partial approximation towards the Tibetan cultural sphere may have facilitated the external view that Kiranti and Tibetan people belong to the same ethnolinguistic group and that they can be identified with a single cover term Khampa $\sim$ Khambu. In summary, there is no old inclusive term for all the groups of the Kirãt, and the assumption of their ethnological and, consequently, linguistic unity is based on external perception and the shared history of these groups rather than relevant empirical evidence.

\subsection{Linguistic Arguments}

Generally, little research on the definition of a coherent Kiranti subgroup has been carried out. Most authors take the existence of such a coherent subgroup for granted. Notable exceptions to this view are the statements by Ebert (2003: 516) that the coherence of Kiranti constitutes a received opinion rather than an empirically proven fact and by Hanßon in an unpublished report cited in Ebert $(2003: 516)$ that

21 The Nepali word Kirẫt, from which the linguistic designation has originated, is an adjective derivation from the loconym Kirã̃t. 
the cluster of Kiranti languages 'results from several migration waves of Tibeto-Burman groups that have influenced each other for a longer period'. Likewise, Winter (1986b) remains sceptical about the phylogenetic unity of Kiranti.

The view of Ebert (2003) is evaluated in Genetti (2016:142) with regard to new descriptive materials and recent work on sound correspondences and lexical isoglosses (cf. section 2). Genetti (2016:142) finds that the new research is an important step forward, but maintains that 'the sound changes do not work like clockwork, isoglosses do not bundle neatly, and the evidence can appear contradictory'. Jacques (2012: 84) likewise adapts a cautious view by stating that ' $[\mathrm{t}]$ his group [= Kiranti] may be paraphyletic, since no common innovations in the vocabulary have been detected. A possible common Kiranti morphological innovation is the \#-nV portmanteau 1>2 suffix'. ${ }^{22}$ As late as 2017, Michailovsky (2017: 647) concedes that 'the number of common innovations that I can cite to justify the status of Kiranti as a clade within Sino-Tibetan remains disappointingly small'.

In the following, we will discuss the arguments brought forward for the identification of a coherent Kiranti subgroup of Trans-Himalayan. This involves lexical arguments (§ 3.2.1), phonological arguments (§ 3.2.2) and innovations in the agreement morphology ( $\$ 3.2 .3)$. Certain linguistic arguments must be dismissed as irrelevant for the phylogenetic unity of Kiranti, since they constitute shared retentions from a more ancient common linguistic ancestor. This concerns the existence of complex biactantial agreement morphology (cf. $§ 3.2 .3)$ and, in part, the lexemes reconstructed by Opgenort $(2005,2011,2014)$ and Jacques (2017) (cf. $§$ 3.2.1).

\subsubsection{Lexical Arguments}

In the domain of lexical arguments, certain contributions aim to show explicit shared innovations of Kiranti, i.e. Michailovsky (2017: 647) and Jacques (2017: 187), whereas others reconstruct Proto-Kiranti lexemes and therefore implicitly assume the existence of a common ancestor, i.e. Opgenort $(2005,2011$, 2014) and Jacques (2017). We will first discuss the lexical reconstruction before turning to the explicit lexical innovations.

Lexical reconstruction Opgenort (2005: 337-399) provides a comparative Kiranti lexicon with reconstructed Kiranti initial segments, but without providing reconstructed lexical roots, and the respective Proto-Tibeto-Burman roots taken from Matisoff (2003). ${ }^{23}$ Opgenort's list contains 255 entries, but many entries actually consist of numerous etymologically distinct roots attested each only in a subset of Kiranti languages, often with clearly delimited distributions. Of course, this may reflect shared losses of potential subgroups, but for lexical reconstruction, these entries are not valid, since they cannot be viewed a priori as etyma shared by all Kiranti subgroups. This concerns for example the entries for 'arm, hand', 'ask for, beg,' 'axe', 'be (identity)', 'bear (n)', 'bite, peck', 'blow (by mouth)', 'causativiser', 'cheek', 'dirtiness of the body', 'dress', 'fear (n)', 'finish, complete', 'follow, go after,' 'give,' 'hang up, suspend', 'hear', 'new', 'one', 'question', 'say', 'search, look for, 'spittle, saliva, 'sweet', 'tiger, leopard', 'wash (up, oneself), bathe', 'wash, rinse', 'what', 'wind (n)' or 'wring, squeeze' (cf. also the discussion of the lexical isoglosses by Opgenort in $\S 2.4)$.

\footnotetext{
22 This innovation will be reviewed in $\S$ 3.2.3.

23 Proto-Tibeto-Burman is either a synonym for Proto-Trans-Himalayan/Proto-Sino-Tibetan (cf. e.g. van Driem 2002, 2005, 2011, 2015b; Blench/Post 2014) or, in the Sino-Tibetan model (Benedict 1972; Bradley 2002; Matisoff 2003; Thurgood/ LaPolla 2003), the common ancestor of all Trans-Himalayan languages except Sinitic, which is assigned an own primary branch beside Tibeto-Burman in a binary family tree.
} 
Additionally, certain reconstructions evince irregular reflexes in individual or several daughter languages which weaken the proposed reconstruction, since the correspondences may constitute phonetic look-alikes rather than true cognates, e.g. Bantawa in 'arm, hand', Khaling and Dumi in 'beat, strike', Dumi, Bahing, Sunwar, Khaling and Yamphu in 'big, large, great', Yamphu in 'bind, tie', Dumi and Khaling in 'call (v)', Limbu in 'carry', Hayu and Chamling in 'chew, masticate', Khaling and Dumi in 'cloth, wear', Bahing and Sunwar in 'come up', Yamphu in 'cow', Chamling in 'dance (n)', Chamling in 'dry, dry up', Khaling and Dumi in 'ear', Dumi and Bantawa in 'follow, go after', Hayu in 'hang up, suspend', Bantawa and Limbu in 'hate (n)', Chamling in 'jump', Khaling in 'know (by learning)', Sunwar and Bantawa in 'lizard', Yamphu in 'obey', Limbu in 'pick up', Yamphu in 'pinch, nip, sting (by insect)', Jero and Wambule in 'smell', Kulung in 'stretch', Limbu in 'twist', Limbu in 'white', Sunwar and Hayu in 'write'.

Finally and more importantly with regard to the topic of shared innovations, many lexical roots in Opgenort (2005: 337-399) are not exclusively shared by Kiranti languages, but also attested elsewhere in the language family. This is evident in the list itself where the Proto-Tibeto-Burman reconstructions of Matisoff (2003) given by Opgenort (2005) are etymologically related to the Kiranti forms, e.g. in the entries for 'arrow', 'ashes', 'axe', 'back, behing, after, 'bamboo', 'banana, 'bark, skin', 'bat', 'bear', 'beat, strike', 'before, front', 'bend,' 'bitter, 'black, 'blood', 'blow (by mouth)', 'boil, simmer,' 'bone, 'bow', 'brain', 'calf of leg', 'cloth, wear', 'come (across a horizontal plane)', 'cook, boil', 'cough', 'damage, destroy', 'die', 'dig', 'dirtiness of the body', 'dog', 'dream, 'ear,' 'earth, soil', 'eat', 'eat, bite', 'eye', 'faeces, stool', 'father', 'fingernail,' 'fire', 'fish', 'flesh, meat', 'forget', 'fry', 'give', 'be good, be healthy', 'grind', 'hair', 'hang up, suspend, 'head', 'hear', 'horn', 'house', 'hurt', 'husband,, 'itch', 'jump', 'kill', 'kiss', 'knee', 'laugh', 'leg, foot', 'lick', 'liver', 'louse', 'mankind, person', 'maternal uncle, 'meet, visit', 'moon, 'mortar', 'mother, 'name, 'net', 'nose', 'one', 'pig, hog,

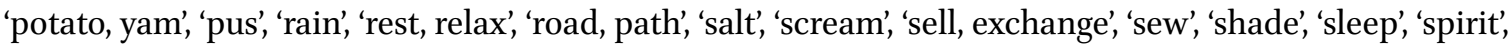

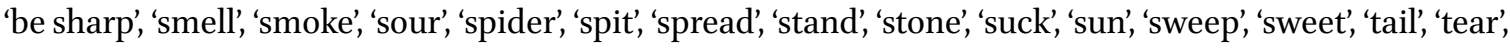
'rend, 'theft, thief', 'tiger, leopard,' 'tongue', 'urine', 'village,, ${ }^{24}$ 'weep, cry', 'what', 'white, 'wind, 'woman', 'wood, firewood,' 'wring, squeeze', 'write', 'year', 'yellow'. ${ }^{25}$

Further examples of extra-Kiranti cognates not attested in the reconstruction of Matisoff (2003) are given in Table $10 .{ }^{26}$ The remaining shared lexical items may be at least partially attributable to borrowing

24 The treatment of * $\mathrm{del}$ as a shared lexical innovation of Kiranti ( cf. Michailovsky 2017: 647) is treated below.

25 Note, however, that the reconstructions of Matisoff (2003) used by Opgenort (2005) have faced substantial criticism (cf. Sagart 2006; Hill 2009, 2011), and caution in the use of this reconstruction is advisable.

26 In Tables 10 and 11, the transcription of the respective source is used to represent Kiranti forms and external cognates with the following exceptions. Vowel length in Yamphu and Limbu is transcribed with the IPA symbol $<_{i}>$ rather than the symbol $<\cdot>$ used by van Driem (1987), Rutgers (1998) and Opgenort (2005). Tibetan is transliterated with the system of Wylie (1959), but supplemented with the original 'Ucen spelling. Old Tibetan root forms are marked with $\langle\sqrt{ }\rangle$ (cf. Hill 2012). Old and Written Burmese forms are given in Burmese script and transliteration, transliterated according to the Library of Congress system with two minor modifications following Hill (2012), namely the transliteration of and : as $<$ ? $>$ and $<$ h $>$ instead of $\langle$ '> and $<$ " $>$. Old Chinese reconstructions are accompanied by the respective Chinese characters. Note that Jacques ( 2017) uses a transcription in accordance to the conventions of the IPA, writing a palatal glide with $<j>$, whereas grammars on Kiranti languages and sources on external cognates predominantly use $<y>$ for the same sound. The question mark is used to indicate doubtful cognacy. Note that regular sound correspondences for these presumable cognates have not been established so far. Data on external cognates are from the following sources, if not indicated otherwise: Baxter/Sagart (2014b) and Baxter/Sagart (2014a) for Old Chinese, Hill (2012) and Hill (2019) for Old and Written Burmese and Old Tibetan, Jäschke (1881) for Written Tibetan, Andvik (2010) for Tshangla, van Driem ( 2015a) for Bumthang, van Driem (n.d(b)) for Black Mountain Mönpa, Plaisier (2007) for Lepcha, van Driem (n.d.(c)) for Toto, 
(cf. also § 2.4). In sum, the comparative word list in Opgenort (2005) does not provide conclusive evidence for the coherence of Kiranti as a branch of Trans-Himalayan.

TABLE 10 External cognates for Kiranti lexemes in Opgenort (2005: 337-399)

\section{Lexical item Attestations in Kiranti External cognates}

\begin{tabular}{|c|c|c|}
\hline 'arm/hand' & Khaling khar, Dumi khir & $\begin{array}{l}\text { Lhokpu kur, Dhimal khur, Toto kuü kui, Gongduk } \\
\text { gur, maybe also Chepang krut }\end{array}$ \\
\hline 'be (identity)' & $\begin{array}{l}\text { Bahing ká, khe, gno, Khaling gö-na, Dumi } \\
\text { ginit }\end{array}$ & $\begin{array}{l}\text { Tshangla gi-, Lepcha go 'EQT.COP', ?Gongduk -kə in } \\
\text { måka 'N EG.COP' and -əkə 'INF.PT', ?Mongsen Ao } \\
\text { khà 'have' }\end{array}$ \\
\hline 'be, sit’ & Hayu mut-, Khaling mu-nä, Dumi mint & $\begin{array}{l}\text { Gongduk } m i-\sim m u \text {-, Thangmi mosa 'live, survive', } \\
\text { Chepang } m u \text { - 'be, live' }\end{array}$ \\
\hline 'carry' & Kiranti in general * $(?) k u r-$ & Gongduk kur 'load (n)' \\
\hline 'catch' & $\begin{array}{l}\text { Hayu la-, Khaling 'lwaam-nä, Dumi lopni, } \\
\text { Chamling lhap-, Bantawa lap-(u), Kulung } \\
\text { lamma, Yamphu ra:pma }\end{array}$ & Gongduk la- \\
\hline 'causativiser' & $\begin{array}{l}\text { Jero paccap paccam, Wambule paccam, } \\
\text { Bahing páto, Sunwar 'payk-tsa, Hayu piy, } \\
\text { Thulung bet- }\end{array}$ & $\begin{array}{l}\text { Lhokpu pa- 'do', Dhimal pali ‘do/caus', Written } \\
\text { Tibetan șv byas 'to do (PT)', Qiang } p \text { - 'do', Japhug } \\
\text { pa ‘do' }\end{array}$ \\
\hline 'chicken' & Kiranti in general $*(k) w a$ & $\begin{array}{l}\text { Thangmi wa, Bumthang khawa, Tshangla goga, } \\
\text { Gongduk okə }\end{array}$ \\
\hline 'cloud' & Bantawa $m u k+s a$, Kulung mom & Tshangla mukpa, Chepang mus \\
\hline 'come down' & Kiranti in general ${ }^{*} y V$ - & $\begin{array}{l}\text { Lhokpu yuh-, Thangmi yusa, Bjokapakha yola 'down } \\
\text { there' }\end{array}$ \\
\hline 'come up' & $\begin{array}{l}\text { Bantawa thay-(a), Kulung tho:ma, Limbu } \\
\text { tha:yma }\end{array}$ & 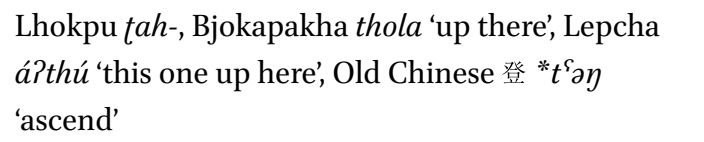 \\
\hline 'cow' & Kiranti in general * $b i(k / t)$ & Lhokpu pi:k, Dhimal piya, Toto piká, Lepcha bík \\
\hline 'do, make’ & $\begin{array}{l}\text { Jero pacap } \sim \text { pacam, Wambule pacam, } \\
\text { Bahing pá-wo, Sunwar 'pa-tsa, Hayu } p a-\text {, } \\
\text { Thulung } b(e) \text { - }\end{array}$ & $\begin{array}{l}\text { Lhokpu pa- 'do', Dhimal pali ‘do/CAUs', Written } \\
\text { Tibetan and byas 'to do (PT)', Qiang } p \text { - 'do', Japhug } \\
\text { pa 'do' }\end{array}$ \\
\hline 'drink’ & Kiranti in general *(?)tu & $\begin{array}{l}\text { Lhokpu tur-, Thangmi tunsa, Written Tibetan g్ gূর } \\
\text { thungs (PT), Lepcha thóng }\end{array}$ \\
\hline 'flour' & $\begin{array}{l}\text { Jero/Wambule phuli, Thulung phul, } \\
\text { Kulung phul, Limbu phe: rum }\end{array}$ & Lhokpu bi:, Bjokapakha bukpu, ?Thangmi phase \\
\hline 'flower' & 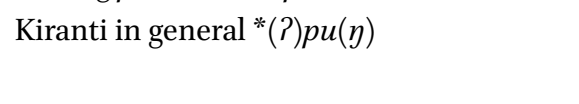 & $\begin{array}{l}\text { Lhokpu pun }(t i) \text {, Thangmi buy 'inflorescence at the } \\
\text { top of a maize or rice blossom' }\end{array}$ \\
\hline 'go' & $\begin{array}{l}\text { Khaling 'khwaan-nä, Dumi khotni, } \\
\text { Chamling khai-ma, Bantawa khat- }(a) \text {, }\end{array}$ & $\begin{array}{l}\text { Lhokpu kat-, Dhimal kha?li, Gongduk grt-, maybe } \\
\text { also Black Mountain Mönpa gö-, Nocte } k a\end{array}$ \\
\hline
\end{tabular}

Kulung khaima, Yamphu khæe?ma

Coupe (2007) for Mongsen Ao, King (2009) for Dhimal, Caughley (2000) for Chepang, Turin (2012) for Thangmi and LaPolla (2003a) for Qiang. Lhokpu, Bjokapakha and Gongduk data are our own. 
TABLE 10 External cognates for Kiranti lexemes in Opgenort (2005:337-399) (cont.)

\begin{tabular}{|c|c|c|}
\hline Lexical item & Attestations in Kiranti & External cognates \\
\hline 'grandchild' & $\begin{array}{l}\text { Jero cacu, Wambule caco, Hayu thastso, } \\
\text { Thulung ciusiu, Dumi tsatsu }\end{array}$ & $\begin{array}{l}\text { Lhokpu } t s u \text {, Dhimal } c u \text {, Toto cuwa, Thangmi cuyũ } \\
\text { (ni) 'great-great-grandchild' }\end{array}$ \\
\hline 'heart' & $\begin{array}{l}\text { Jero tem } \sim \text { tom, Wambule twam, Bahing } \\
\text { thim, theum, Sunwar thun }\end{array}$ & Gongduk tulukpr, Tshangla thinglom \\
\hline 'mouse' & $\begin{array}{l}\text { Jero cicimo cicum, Wambule cicimo, } \\
\text { Bantawa cü-?yü, cük-yü, Kulung chuwi, } \\
\text { Yamphu si?numa, Limbu suba }\end{array}$ & Lhokpu cu, Dhimal juhã, Toto jüwó, \\
\hline 'plaster' & 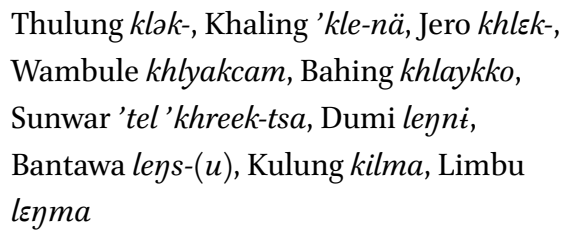 & Lhokpu le:- 'have diarrhoea', Dhimal te: li 'plaster' \\
\hline 'song' & Thulung leolam, Khaling lel, Dumi le: & Dhimal le \\
\hline 'suck' & Kiranti in general *bip- $\sim$ pip- $\sim$ phip- & 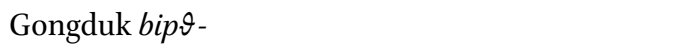 \\
\hline 'suffice' & $\begin{array}{l}\text { Dumi la:tni, Bantawa latt-(u), Kulung } \\
\text { laima }\end{array}$ & Tshangla $\operatorname{la\eta }(k)-$ \\
\hline 'sweet' & $\begin{array}{l}\text { Thulung lem-, Khaling lempä, Dumi lempi, } \\
\text { Bantawa lem+chok, Kulung lemlempa, } \\
\text { Yamphu rim?iye, Limbu lipma }\end{array}$ & $\begin{array}{l}\text { Written Tibetan वेळ źim < *ljem, ?Lhokpu } \operatorname{di}(:) \text {-, } \\
\text { ?Dhimal dirli, ?Toto the-, Old Chinese 甜 *l'em (Hill } \\
\text { 2019) }\end{array}$ \\
\hline
\end{tabular}

The same problem of non-exclusive isoglosses and shared retentions also pertains to the list of reconstructed verbs presented in a supplementary document to Jacques (2017). Of the 290 verb roots reconstructed by Jacques (2017) on the basis of four Kiranti languages, i.e. Wambule, Khaling, Bantawa and Limbu, only 23 are attested in all four languages. 77 roots are attested in three languages and 189 roots are only attested in two languages of the set. Of these 189 roots, 39 are shared by the two Western Kiranti languages Wambule and Khaling and 31 are shared by the two Eastern Kiranti languages Bantawa and Limbu. These 70 roots, thus, do not provide lexical evidence for Proto-Kiranti. Furthermore, many of the reconstructed roots have cognates in other branches of Trans-Himalayan. A selection of external cognates is given in Table 11.

The reconstruction by Jacques (2017), like the one by Opgenort (2005), does not provide conclusive evidence for the validity of a monophyletic Kiranti subgroup. Many of the shared items either constitute shared retentions, are only attested in certain languages or subgroups or may reflect Wanderwörter spread throughout Eastern Nepal. The possibility of extensive lexical borrowing among the Kiranti languages is implicitly acknowledged by Opgenort (2011: 267) by defining Khaling and Dumi as well as Tilung as 'marginal Western Kiranti languages', heavily influenced lexically by Central and Eastern Kiranti languages.

Explicit lexical innovations Explicit lexical innovations are brought forward by Michailovsky (2017: 647 ), i.e. *del 'village' and the Kiranti autonym *rakduy, and by Jacques (2017:187), namely the semantic innovation to express the verb 'to sleep' with a morphologically complex verb stem, consisting of the inherited verb root ip- plus the applicative suffix - $t$ and the reflexive suffix $-s$, thus literally meaning 'to put oneself to sleep'. These lexical innnovations will be discussed in turn. 
TABLE 11 External cognates for reconstructed Kiranti lexemes in Jacques (2017)

\section{Lexical item}

*berr 'fly'

*bla:t 'tell, explain'

*blut 'boil'

*buk 'give birth'

*di: 'go'

*do 'dig'

*duk 'hurt, be ill'

*dum 'meet'

*dza:k 'swim'

*dzokt 'join'

*hopt 'eat, drink, inhale'

*joy 'melt'

${ }^{*} k[e \mid i] p$ 'stick, attach'

*kam 'chew'

*kh[e|i]s 'steal'

*kukt 'bend'

*l[a|o]k 'boil, simmer'

* $l[e \mid i] s$ 'masturbate, have

intercourse'

*makt 'be black'

*nuk 'rub, knead'

* $y[e \mid \varepsilon] t$ 'hurt'

* $y[u \mid i] r$ 'roar'

*yin 'fear, be afraid'

* $p[i \mid e] s$ 'fart'

*prok 'run away'

*sel 'clean, cut out, separate'

*søy 'be clean, be clear'

*tak 'weave'

*tat 'be visible'
External cognates

Old Chinese 飛 *Cə.pə[r], Written Tibetan 쬐주 phur (PT), Tshangla phen-, Gongduk biyəy-, Lhokpu birmah 'wind', Dhimal bherma 'wind'

?Lepcha $f$ lâ 'narrate, describe'

Old Chinese 沸 *Na.p $[u][t]-s$

?Bjokapakha bray-

Tshangla di-, Lepcha $d i(t)$ 'come, approach'

Lepcha $d \dot{u}(n)$, ?Bjokapakha tho-

Old Chinese 毒 *[d] 'uk 'poison', Old Tibetan 5ु't' dug 'poison', Written Burmese ढosर्s tok 'poison', Bjokapakha dok, Lepcha dok, Lhokpu tuk- 'be ill'

?Tshangla rum

?Lepcha zok 'trickle, flow', Lhokpu tse cap-

Bjokapakha tsik 'joint', Old Chinese 節 * $t s^{\varsigma} i k$, Old Tibetan ${ }^{\text {केगा }}$ tshigs 'joint', Old Burmese soø chac < Proto-Burmish *chik 'joint'

Bjokapakha hap- 'eat, devour'

?Bjokapakha $y u$ -

Old Chinese 合 * $m-k^{\varsigma} o p$ 'together, combined' (Hill 2019), Old Burmese mú kap 'join, unite'

?Bjokapakha gam-

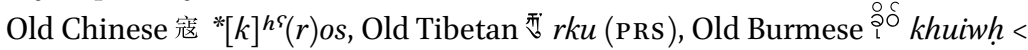
Proto-Burmish *kuiwh

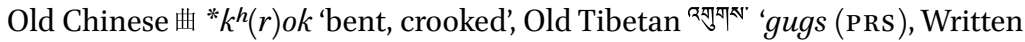
Burmese 6 mon kok< Proto-Burmish *kuk

Bjokapakha lak-

Gongduk lr 'penis', Qiang liaq 'penis', lies, 'sperm', Written Burmese ơ lịh 'penis'

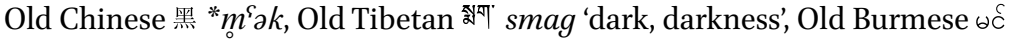
man் 'ink'

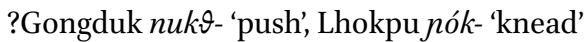

?Gongduk ne- 'hurt'

Old Tibetan 5. $n g u$ 'weep (PRs)', Written Burmese $\underset{1}{\circ} \dot{n} u i<$ Old Burmese *nuiw 'weep', Old Chinese 牌 * $g^{\varsigma} u$ 'roar, wail' (Hill 2019)

?Gongduk nrynry 'anxiety'

Bjokapakha $p h \dot{t}$-, Thangmi $p a ̆ i$ 'fart (n)', Written Tibetan झेषे phyen 'flatulence'

Old Chinese 奔 * $p^{\varsigma} u r$ 'run', Old Tibetan 정ㅇ phun 'accomplish, complete'

Old Chinese 瑤 *[ $\left[s^{h}\right]^{\varsigma}$ 'ar-s 'bright and white', Old Tibetan $\sqrt{ }$ stsal 'clean, clear', Old Burmese os s $\bar{a}<{ }^{*}($ ?) săl 'shine', Bjokapakha say- 'clean, clear', Dhimal selli

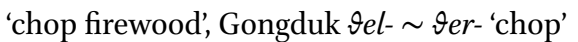

Old Chinese 淨 * $N$-tsey-s 'clean (adj),

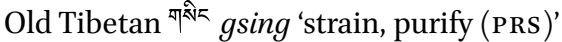

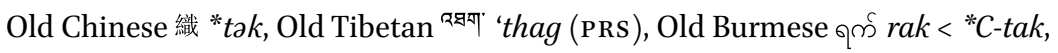
Gongduk ka tuk-

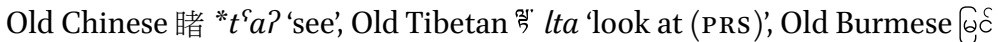

mrai < *mC-tay'see' 
TABLE 11 External cognates for reconstructed Kiranti lexemes in Jacques (2017) (cont.)

Lexical item External cognates

\begin{tabular}{|c|c|}
\hline *tsam 'chop, splice' & Gongduk Эəp-, Bjokapakha zam- \\
\hline *tshu[y|k]-si 'cough' & Bjokapakha tsuyphuy-, Burmese $\curvearrowright_{1}^{\circ}$ chuih \\
\hline *way 'enter, arrive' & 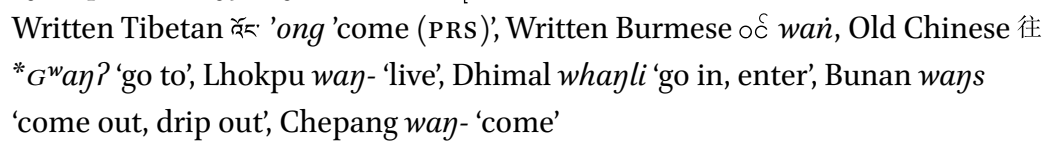 \\
\hline *Pak 'be displeased, feel pain' & 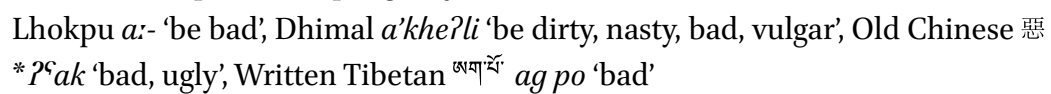 \\
\hline *?es 'defecate' & Toto em-, Dhimal emli 'press, massage', Lhokpu er 'faeces' \\
\hline *Pwa 'eat by biting' & ?Gongduk gr-, Bjokapakha bak- 'bite' \\
\hline *Pwart 'wound' & Gongduk khat 'wound (n)', Thangmi gare 'wound (n)' \\
\hline
\end{tabular}

Concerning Michailovsky's suggested innovations, he himself acknowledges that neither of these innovations is attested in Hayu. The root for 'village' is, according to Benedict (1972), also attested in Lepcha as tyol, although this lexeme is not found in the grammar of Plaisier (2007). The Kiranti autonym *rakduy may have a cognate in Lepcha too, namely the autonym roy, which may, however, also be a look-alike. Furthermore, certain Kiranti languages do not exhibit this self-designation, for example Mewahang. This may very well represent secondary loss of the inherited term, but this assumption again enables one to speculate that perhaps other linguistic or ethnic groups of the wider region also originally inherited the same autonym and later replaced it by newer designations. For both proposed innovations, the problem of borrowing applies, since Kiranti languages seem to have borrowed extensively from each other, especially in the lexical domain (cf. Opgenort 2011: 267).

The semantic innovation concerning the verb 'to sleep' in Jacques (2017:187) is a convincing candidate for a shared innovation of all Kiranti languages. However, a problem of his assumption is its speculative character with regard to the derivation of a reflexive from an applicative stem, since such a derivation is 'indistinguishable from a direct derivation from the bare root' (Jacques 2017: 187) due to the reduction of the consonant cluster $i p+t+s i>$ [ipsi]. Therefore, the form could also constitute a simple reflexive derivation in some Kiranti languages and a reflexive of an applicative in others.

The reflexive conjugation in -si has been mixed partially or completely with the causative conjugation in $-s$ in most Kiranti languages by loss of the final high vowel of the reflexive suffix (Jacques 2017: 182). This constitutes another problem for Jacques' assumption, because it is possible that the form [ips] for 'to sleep' in certain Kiranti languages does not derive from a reflexive of an applicative derivation, but could also derive from a causative derivation in -s, although with unclear semantic motivation, or simply from analogical extension or confusion of individual derivational paradigms.

Finally, the intensive contact situation between Kiranti languages together with the retention of the inherited agreement and valence morphology, including reflexive ${ }^{*}-s$ and applicative/causative ${ }^{*} t$ (Benedict 1972: 97; Jacques 2017: 180, 182), may have easily led to morphological calques, which would have only been enhanced and facilitated by the cognacy of the inherited morphology. Similar morphological convergence phenomena are attested in well-known Sprachbünde (cf. Thomason 2001: 105-125).

In summary, the lexical evidence brought forward for the coherence of a Kiranti branch is inconclusive. This corresponds to the general observation that lexical evidence is less convincing than morphological evidence, since the vocabulary is more readily replaced (cf. Meillet 1925: 33). 


\subsubsection{Phonological Arguments}

Candidates for shared phonological innovations are even rarer than lexical arguments. The only two proposals are the change in place of articulation of the initial nasal in the lexeme for 'name', from Proto-

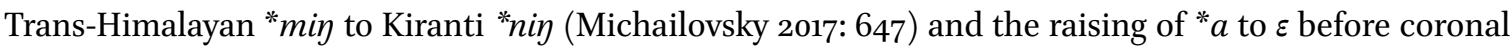
consonants, namely $t$ and $l$ (Jacques 2017: 204-205).

The phonological innovation for 'name' is another good candidate for a shared innovation, but the development is not shared by Limbu and Hayu, which retain min (Michailovsky 2017: 647). The absence of the expected reflex in Hayu and Limbu is a serious flaw for the strength of the argument, since it leaves the possibility open that other languages not traditionally considered to be part of Kiranti may very well be more closely related to certain Kiranti languages, as the attestation of the sound change does not seem to be a necessary prerequisite to belong to the Kiranti subgroup, as the Hayu and Limbu reflexes imply.

The proposal by Jacques (2017:204-205) of raising of * $a$ to $\varepsilon$ before $l$ and $t$ is weakened by the existence of exceptions, that is lexemes with codas - al or -at (Jacques 2017: 205). Furthermore, this sound change is also attested in a number of other Trans-Himalayan languages and seems to constitute an unmarked development, e.g. Dhimal (cf. Grollmann/Gerber 2018), Lhasa Tibetan (cf. DeLancey 2003: 271), Dzongkha (cf. van Driem 1998: 105) or Tshangla (cf. Andvik 2010). ${ }^{27}$

Additionally, in the Upper Arun language Lohorung, the verb 'to go' shows the stem alternation khstkhar-, the stem allomorph khar- appearing before vocalic suffixes and thus showing a lenition of underlying $t$ in intervocalic position. Since the lenition $t>r$ in this verb root is not attested in Mewahang or Yamphu, i.e. the alleged closest relatives of Lohorung, this seems to be a recent individual innovation of Lohorung. This observation contradicts Jacques' assumption that the raising of * $a$ before coronal $t$ and $l$ constitutes a Proto-Kiranti innovation because the root vowel $a$ was obviously retained until PreLohorung. Both alternative explanations for the Lohorung allomorphy, namely the retention of an old Proto-Kiranti alternation between khet- and khar-, which was levelled in every other Kiranti language, and the change back from $\varepsilon$ to $a$ in Lohorung following the lenition of intervocalic $t$, are implausible. Therefore, the raising of $a$ to $\varepsilon$ may rather constitute parallel independent innovations in various Kiranti subgroups than a shared innovation on the Proto-Kiranti level.

Several other Kiranti languages also show the root vowel $a$ in the verb 'to go', e.g. Nachiring khaim, khat- khat-, Kulung khat- khai- khan- (Tolsma 2006), Bantawa khat- khar- (Doornenbal 2009) or Chamling khoima, khat- (Singh Rai 2012). The data from these languages also corroborates the possibility that ${ }^{*} a>\varepsilon / \_t$, l was an independent innovation in various groups instead of a shared innovation of the Proto-Kiranti level.

\subsubsection{Verbal Morphology}

The Kiranti languages are a prime example for the characteristic Trans-Himalayan feature of complex, biactantial agreement morphology on the verb, which is also attested in Rgyalrongic, Qiangic, West Himalayish, Dhimal, Kuki-Chin, Midźuish, Nungish, Kachinic, Thangmi, Dolakha Newar, Chepang, Kham, Raji-Raute, Gongduk or Black Mountain Mönpa. The reconstruction of agreement morphology to Proto-Trans-Himalayan has been a fiercely debated topic of historical-comparative Trans-Himalayan linguistics in the last decades. ${ }^{28}$ Factually, the arguments for the reconstruction of at least a part of the biactantial agreement morphology to Proto-Trans-Himalayan, cf. especially DeLancey (2010) and Jacques

\footnotetext{
27 Cf. Tshangla she- 'to kill' < ${ }^{*}$ sat, as reflected in Thangmi, Lhokpu or Old Burmese, all sat.

28 The agreement morphology is seen as an archaic trait to be reconstructed to the proto-language by Bauman (1974, 1975), DeLancey (1989, 2010, 2011, 2013, 2015), van Driem (1993d, 1995, 2013), Sun (1995) or Jacques (2010, 2012). The opposite
} 
(2012), are more convincing in view of the empirical evidence and the geographical and phylogenetic distribution of the relevant morphology. As a consequence, the attestation of complex, biactantial agreement morphology in Kiranti cannot be viewed as a shared innovation of the Kiranti languages, but as shared retention from Proto-Trans-Himalayan. ${ }^{29}$ Shared innovations in Kiranti agreement morphology are implicitly provided in the work by van Driem (1990a, 1991, 1992b, 1993d, 1997) on the agreement morphology of Kiranti and Trans-Himalayan in general.

Van Driem (1990a) presents a reconstruction of the Proto-Kiranti verbal agreement slot model, based on data from Limbu, Dumi, Hayu, Kulung and Thulung. The agreement morphemes are compared and Proto-Kiranti forms are reconstructed, assigned to functional slots and set in syntagmatic relation to each other. The original model of 1990 was later adjusted and modified due to the inclusion of Bahing (van Driem 1991) and Lohorung (van Driem 1992b) and a new analysis of the Limbu verbal morphology (van Driem 1997). Table $12^{30}$ presents the final version of the Proto-Kiranti verbal slot model as described in van Driem (1997). Van Driem (1993) has likewise provided an account on the verbal agreement morphology of Proto-Tibeto-Burman, ${ }^{31}$ based on a comparison of his Kiranti reconstruction with the agreement morphology of Rgyalrong, the three Qiangic languages Tangut, Qiang and Prinmi, the three Nungish languages Rawang, Nusu and Trung, Jinghpaw, Nocte, Kham and the Kukish language Lakher. The result of this comparison is shown in Table 13. The reconstruction of the Proto-Tibeto-Burman agreement morphology by van Driem allows for a historical evaluation of his Proto-Kiranti reconstruction and the identification of defining morphological and semantic innovations in Kiranti verbal morphology. In the following, the validity of these innovations will be discussed.

view, namely that the morphology constitutes a shared or several parallel innovations in the daughter languages and cannot be reconstructed to Proto-Trans-Himalayan, is taken by Matisoff (1993), Nishi (1995) and most notably LaPolla (1989, 1992, 1994, 2001, 2003b, 2012).

29 In his earlier publications, LaPolla (1989, 1992, 1994, 2001) assumes that the complex agreement morphology in various branches constitutes numerous independent innovations. However, in later publications, LaPolla (2003b, 2012) views the morphology of Kiranti, West Himalayish, Rgyalrong and Nungish as a shared innovation not cognate to the agreement morphology of Qiangic, Northern Naga and other branches that he does not mention explicitly like Gongduk, Black Mountain Mönpa, Thangmi or Dhimal. Therefore, even though an opponent to the reconstruction of agreement morphology to Proto-Trans-Himalayan, LaPolla does not view Kiranti agreement morphology as a defining shared innovation of Kiranti. This view is shared by proponents of the reconstruction of agreement morphology to Proto-TransHimalayan.

The slots in Tables 12-14 differ from the slot alignment in van Driem's model to a minor degree. Van Driem's slot 6, which is exclusively occupied by the second auxiliary, is not reproduced in Table 12, and the subsequent slots therefore have a different number value in Table 12 than in van Driem (1990a, 1991, 1992b, 1997). Concerning the Proto-Tibeto-Burman slots of van Driem (1993d: 320, 326), slot 6, which is occupied by the dual patient morpheme -si, is not reproduced in Table 13 in accordance with the new analysis of the Limbu verb and the insight that the second dual slot in the ProtoTibeto-Burman model of 1993 should be removed and viewed as a Kiranti-specific innovation not reconstructible to the proto-language (cf. van Driem 1997: 172-173). Therefore, suffix slot 7 in van Driem's (1993d) model corresponds to suffix slot 6 in Table 13 .

'Tibeto-Burman' is used by van Driem in several publications (e.g. 2002, 2005, 2011, 2015b) to refer to the whole family and not to one of the major subgroups sensu Benedict (1972) or Matisoff (2003). However, van Driem (1993d) uses the term 'Tibeto-Burman' in the same sense as Benedict or Matisoff, that is as the designation of the primary subgroup vis-àvis Sinitic (and Karenic). To avoid confusion, we will retain the original designation 'Proto-Tibeto-Burman' used by van Driem (1993d) in the following discussion. 


\begin{tabular}{lll} 
TABLE 12 & \multicolumn{2}{c}{$\begin{array}{l}\text { Proto-Kiranti agreement morphology } \\
\text { (van Driem 1990a, 1991, 1992b, 1997) }\end{array}$} \\
\hline Morpheme & Meaning & Slot \\
\hline${ }^{*} m e-$ & 3PL.A & -1 \\
${ }^{*}-n s ̌ i$ & REFL & 1 \\
${ }^{*}-t \varepsilon$ & PT & 2 \\
${ }^{*}-k$ & NPT & 2 \\
${ }^{*}-n a$ & 2 & 3 \\
${ }^{*}-n y a$ & 1SG $\rightarrow 2$ & 3 \\
${ }^{*}-c i$ & DU & 4 \\
${ }^{*}-\eta(a)$ & 1SG & 5 \\
${ }^{*}-u$ & $3 . P$ & 5 \\
${ }^{*}-k$ & 1PL & 6 \\
${ }^{*}-n i$ & 2PL & 6 \\
${ }^{*}-m$ & 1/2PL.A & 6 \\
${ }^{*}-c i$ & $3 \mathrm{DU} / \mathrm{NSG}$ & 6 \\
${ }^{*}-y a$ & EXCL & 7 \\
${ }^{*}-i$ & INCL & 7 \\
& & \\
& & \\
& & 6
\end{tabular}

\begin{tabular}{lll} 
TABLE 13 & \multicolumn{2}{c}{$\begin{array}{l}\text { Proto-Tibeto-Burman agreement } \\
\text { morphology (van Driem 1993d, 1997) }\end{array}$} \\
\hline Morpheme & Meaning & Slot \\
\hline${ }^{*} k \varepsilon-$ & 2 & -2 \\
${ }^{*} a-$ & 1 & -2 \\
${ }^{*} t a-\sim{ }^{*} n a-$ & MS & -2 \\
${ }^{*} m e-$ & PL.A & -1 \\
${ }^{*}-n s ̌ i$ & REFL & 1 \\
${ }^{*}-t \varepsilon$ & PT & 2 \\
${ }^{*}-\eta a \sim{ }^{*}-a \sim{ }^{*} \eta$ & 1SG & 3 \\
${ }^{*}-n a$ & 2 & 3 \\
${ }^{*}-n y a$ & 1SG $\rightarrow 2$ & 3 \\
${ }^{*}-s i$ & DU.A & 4 \\
${ }^{*}-u$ & $3 . P$ & 5 \\
${ }^{*}-a$ & 3 & 5 \\
${ }^{*}-n i$ & 2PL & 6 \\
${ }^{*}-i$ & 1/2PL & 6 \\
${ }^{*}-k$ & 1PL & 6 \\
& & \\
& &
\end{tabular}

From Proto-Tibeto-Burman to Proto-Kiranti The comparison of Tables 12 and 13 reveals that most of the morphemes reconstructed for Proto-Kiranti are also assumed by van Driem (1993d) for the more ancient mother tongue of the whole language family and therefore constitute shared retentions in the Kiranti languages.

Differences between van Driem's Proto-Kiranti and Proto-Tibeto-Burman reconstructions are shown in Table 14. Morphemes that are reconstructed by van Driem to Proto-Tibeto-Burman, but not to ProtoKiranti are the three prefixes in the first prefix slot of Proto-Tibeto-Burman, i.e. * $k \varepsilon-$, * $a$ - and ${ }^{*} t a-\sim{ }^{*} n a$-, and the third person suffix * $a$.

Innovative morphemes of Kiranti include the exclusive marker *-ya, the suffix for first or second person plural agents ${ }^{*}-m$, the non-past tense marker ${ }^{*}-k$, which stands in equipollent opposition to the past tense morpheme ${ }^{*}-t \varepsilon$, whereas the marking of tense in Proto-Tibeto-Burman is analysed as a privative opposition with a marked past tense and no marker for non-past, and the third person non-singular suffix in slot 6.

Additional innovations of the Kiranti agreement morphology are the semantic narrowing of the prefix * $m e$ - from a marker of agent plurality to a marker of a third person plural agent, the movement of the first person singular marker ${ }^{*}-\eta a \sim{ }^{*}-a \sim{ }^{*}-\eta$ from slot 3 to slot 5 , the formal and functional change attested in the dual marker, from Proto-Tibeto-Burman *-si 'DU.A' to Proto-Kiranti *-ci 'DU', with phonetic hardening, but semantic widening, the semantic change of the marker * $i$ from first and second person plural to inclusive, the different slot assignment of this inclusive marker, syntagmatically following the morphemes * $k$ and *-ni rather than sharing a slot with the latter two markers, and the inclusion of auxiliaries into the slot model in Kiranti which are the historical explanation for the phenomenon of double agreement marking on the verb, the so-called 'copy slots' in the terminology of van Driem (1990a). Most of 
TABLE 14 Changes from Ртв to PK according to van Driem (1990a, 1991, 1992b, 1993d, 1997)

\begin{tabular}{|c|c|c|c|c|c|c|}
\hline \multicolumn{3}{|c|}{ Ртв morpheme Ртв meaning Ртв slot } & \multicolumn{3}{|c|}{ PK morpheme PK meaning PK slot } & \multirow{2}{*}{$\begin{array}{l}\text { Change } \\
\text { loss }\end{array}$} \\
\hline${ }^{*} k \varepsilon-$ & 2 & -2 & - & - & - & \\
\hline${ }^{*} a-$ & 1 & -2 & - & - & - & loss \\
\hline${ }^{*} t a-\sim n a-$ & MS & -2 & - & - & - & loss \\
\hline *- $a$ & 3 & 5 & - & - & - & loss \\
\hline- & - & - & ${ }^{*}-k$ & NPT & 2 & innovation \\
\hline- & - & - & *-ya & EXCL & 7 & innovation \\
\hline- & - & - & ${ }^{*}-m$ & 1/2PL.A & 6 & innovation \\
\hline- & - & - & ${ }^{*}-c i$ & $3 \mathrm{DU} / \mathrm{NSG}$ & 6 & innovation \\
\hline$*_{-}-s i$ & DU.A & 4 & $*_{-}-c i$ & $\mathrm{du}$ & 4 & $\begin{array}{l}\text { hardening of } * / s / \text {, semantic } \\
\text { change }\end{array}$ \\
\hline${ }^{*}-\eta a \sim-a \sim-\eta$ & 1SG & 3 & ${ }^{*}-\eta(a)$ & $1 S G$ & 5 & syntagmatic shift \\
\hline${ }^{*} m e-$ & PL.A & -1 & *me- & 3PL.A & -1 & semantic change \\
\hline${ }^{*}-i$ & $1 / 2 \mathrm{PL}$ & 6 & $*_{-i}-$ & INCL & 7 & $\begin{array}{l}\text { semantic change, syntagmatic } \\
\text { shift }\end{array}$ \\
\hline
\end{tabular}

these divergences are not convincing evidence for a coherent Kiranti subgroup, since they do not qualify as diagnostic shared innovations.

First, the apparent losses are no significant innovation, since agreement morphology has been lost in a large number of Trans-Himalayan branches, sometimes even in languages with close relatives which retain the respective morphology. Illustrative examples with plausible explanations are provided by DeLancey (2010: 22-30). Lhokpu and Toto may be added to DeLancey's list, since these two languages, despite their presumable close relationship to Dhimal and Kiranti (cf. Gerber et al. 2016; Grollmann/ Gerber 2018), show no or only speculative traces of agreement morphology. The loss of four morphemes in Kiranti can therefore be judged as non-indicative for a closer relationship.

Second, the presumable innovations in inherited agreement morphology shown in Table 14 are very small adjustments, expressing fine semantic nuances and minor and uncertain phonological or syntagmatic changes. Importantly, the identification of shared innovations depends crucially on the accurateness of the Proto-Kiranti and Proto-Trans-Himalayan reconstructions by van Driem (1990a, 1991, 1992b, 1993d, 1997). However, the question of how many and which morphemes can be reconstructed to the Trans-Himalayan mother tongue as well as the exact functional load and syntagmatic position of these morphemes in Proto-Trans-Himalayan is still not solved conclusively, and the reconstruction by others, e.g. DeLancey $(1989,2011)$ or Jacques $(2012)$, is more cautious than the one of van Driem (1993d) or Bauman (1975) and only involves a handful of morphemes instead of a fully-fledged slot model or paradigm. Therefore, only after the establishment of a consensus regarding the number and form of reconstructed morphemes can the agreement systems of potential branches of Trans-Himalayan be convincingly examined for innovations. As a consequence, we will restrict the discussion here to two presumable shared morphological innovations of Kiranti sensu van Driem (1990a, 1991, 1992b, 1993d, 1997), namely the non-past marker ${ }^{*}-k$ and the exclusive morpheme ${ }^{*}-y a$, and show that these do not stand closer scrutiny, before critically reviewing another suggested morphological innovation of Kiranti, namely the $1 \rightarrow 2$ marker ${ }^{*}-n(y) V$. 
Non-past * $k$ The non-past marker $-k$ is restricted in this clear form and function to the Upper Arun languages Mewahang and Lohorung. The evidence of van Driem (1991: 349-350, 1992b: 69) for the reconstruction of * $k$ to Proto-Kiranti comes from the Lohorung non-past suffix $-k$, the Hayu non-singular nonpast morpheme $-k$, the glottal stop in the Limbu first person non-past morpheme ${ }^{2} \varepsilon$ and the Dumi non-past marker $-t$. The Hayu, Limbu and Dumi evidence is highly speculative. The Hayu non-past marker occupies a posterior slot and may reflect a recent grammaticalisation. The Dumi non-past morpheme $-t$ is more likely to be cognate to the past morpheme $-t$ in Bahing, Sunwar and Khaling (cf. van Driem 1991; Borchers 2008; Jacques et al. 2012), the past morpheme $-r \sim-d \sim-t$ in Thulung (cf. Lahaussois 2002), the non-past marker $-d V$ in Nachiring and the perfect marker in Upper Arun, $-? d a$ in Mewahang and Lohorung and -Pitta in Yamphu (cf. Rutgers 1998). This latter hypothesis has the advantage of evincing the regular sound correspondence Western Kiranti $t$ : Thulung $d$ : Khambu $d$ : Upper Arun $d$ :Yamphu $? \sim \varnothing$ (cf. section 2) and of suggesting a complex, but not implausible semantic history for this morpheme.

It may therefore be more appropriate to define the non-past morpheme $-k$ as an innovation of the Upper Arun languages based on the recent grammaticalisation of an auxiliary. The anterior position of this recent suffix is not remarkable, given that auxilaries in Mewahang and Lohorung are added directly to the verb root, e.g. Mewahang has- 'burn' + let- 'inchoative AUX' > har-let-a [burn-AUX.INCH-3.PT] 'it began to burn [again]', Lohorung pen- 'stay, sit' + ca- 'perfomative/progressive AUX' > pen-ca-iye [sitAUX.PERF-ADH] 'let's relax!' (cf. van Driem n.d.(a)). Yamphu, the third Upper Arun language, also exhibits a non-past morpheme, but it is etymologically unrelated to the Mewahang and Lohorung marker $-k$, viz. -Pind (cf. Rutgers 1998: 114-118), a morpheme which probably derives from an independent auxiliary (Rutgers 1998: 118). The occurrence of a new, etymologically unrelated non-past marker in Yamphu vis-àvis the non-past morpheme in Mewahang and Lohorung shows that such tense markers readily grammaticalise from former auxiliaries. This is further evidence for the assumption that the marker $-k$ in Mewahang and Lohorung is recent and does not hark back to Proto-Kiranti. ${ }^{32}$

Exclusive *-ya Van Driem (1990a: 44) assumes an innovative exclusive morpheme *-ya for Proto-Kiranti. His analysis is based on data from Dumi, Hayu, Kulung and Limbu. However, the Kulung and Limbu comparanda are unconvincing. For Kulung, van Driem (1990a: 44) assumes that the morpheme $-y a$, which is analysed as a first person plural patient marker, is cognate to the vocalic exclusive morphemes in Dumi and Hayu. In Tolsma (2006: 68), - ya is analysed as a first person plural non-preterite marker and can also be combined with the exclusive morpheme $-k a$, namely in -yaka '1PL.ExCL'. Therefore, the Kulung morpheme $-y a$ is obviously etymologically distinct from the exclusive marker $-k a$ and not cognate to the Hayu and Dumi vocalic exclusive markers.

32 It is possible that the Mewahang and Lohorung non-past suffix $-k$ is etymologically related to the non-past marker $-y u k$ attested in Athpahariya and Belhare and deriving from the lexical verb yuy- 'to stay' (cf. Ebert 1997a: 45-46; Bickel 2003: $551,554)$, since both Mewahang and Lohorung exhibit a verb class which shows a stem augment $-y u \sim-u$ between the verb root and the non-past suffix $-k$. It is conceivable that this stem augment actually derives from the same auxiliary as the non-past marker $-k$, i.e. ${ }^{*}-y u k \sim{ }^{*}-u k$, and that some yet unknown phonological, morphological or semantic conditioning factors led to a split in the distribution of the non-past auxiliary, appearing as $-u k \sim-y u k$ with certain verbs and as $-k$ with all others. The consequence of this observation would be that the non-past suffix *-k, in the form *-yuk, could be reconstructed back to a more distant common ancestor including the Greater Yakkha languages Athpahariya and Belhare. 
For Limbu, van Driem (1990a: 44) assumes the cognacy of the first person prefix $a$ - with the Kulung morpheme $-y a$ and the Dumi and Hayu exclusive markers, but also identifies the Limbu exclusive marker - $g$ e as an amalgamation of first person plural * $k$ plus the exclusive suffix *-ya. This, however, is an illegitimate proceeding, since a single morpheme in one language should not be compared to several morphemes in another language. The first person prefix $a$ - in Limbu can be derived from the homophonous possessive prefix and is not etymologically related to the various exclusive markers in other Kiranti languages.

This leaves only the Hayu and Dumi data as potential evidence for a Kiranti exclusive marker *-ya. Indeed, the exclusive marking of these two languages, along with that of Kohi, Khaling, Jero, Wambule and Bantawa, suggest a vocalic exclusive marker $-V$, since the inclusive and exclusive non-singular forms in their verbal paradigms are differentiated by apophony of the vowel of the dual and plural suffix. Exclusive markers with initial velar stop, i.e. $-k a \sim-g a \sim-g e$, which are attested in a number of other Kiranti languages, namely Bahing, Sunwar, Wambule, Thulung, Kulung, Nachiring, Sampang, Chamling, Bantawa, Puma, Mewahang, Lohorung and Limbu, are analysed by van Driem (1990a) as amalgamations of the first person plural suffix * $-k$ and the exclusive morpheme * $-y a$. Table 15 provides an overview of non-singular first person agreement morphology in selected Kiranti languages. ${ }^{33}$

\begin{tabular}{lllll} 
TABLE 15 & Inclusive-exclusive marking in Kiranti languages (intransitive paradigm) \\
\hline Language & lDU.INCL & 1DU.EXCL & 1PL.INCL & 1PL.EXCL \\
\hline Hayu & $-t s h i(k)$ & $-t s h o(k)$ & $-k e$ & $-k o(k)$ \\
Bahing & $-s a$ & $-s u k u$ & $-y a$ & $-k a$ \\
Wambule & $-\eta c i$ & $-\eta c u k u$ & $-k i$ & $-k u$ \\
Jero & $-y c i$ & $-\eta c u(w a)$ & $-k i$ & $-k u(w a)$ \\
Thulung & $-t s i$ & $-t s u k u$ & $-q i$ & $-k u$ \\
Dumi & $-i$ & $-\dot{i}$ & $-k i$ & $-k a$ \\
Khaling & $-i$ & $-u$ & $-k i$ & $-k n$ \\
Kohi & $-s i$ & $-s u$ & $-k i$ & $-k j$ \\
Kulung & $-c i$ & $-c i k a$ & $-y a$ & $-y a k a$ \\
Nachiring & $-c i$ & $-c i k a$ & $-i$ & $-i k a$ \\
Bantawa & $-c i$ & $-c a$ & $-i n$ & $-i n k a$ \\
Puma & $-c i$ & $-c i k a$ & $-i / e$ & $-i n k a$ \\
Mewahang & $-c i$ & $-c i g a$ & $-i n$ & $-i k k a$ \\
Limbu & $a--s i$ & $-s i g e$ & $a-$ & $-i g e$
\end{tabular}

Data in Table 15 are taken from the following sources: Hayu (Michailovsky 1988), Bahing (van Driem, 1991), Wambule (Opgenort 2004a), Jero (Opgenort 2005), Thulung (Lahaussois 2002), Dumi (van Driem 1993a), Khaling (Jacques et al. 2012), Kohi (Lahaussois 2009), Kulung (Tolsma 2006), Nachiring (own data), Bantawa (Doornenbal 2009), Puma (Bickel et al. 2007b), Mewahang (own data) and Limbu (van Driem 1987). Since most Kiranti languages show a binary tense distinction with a marked member, the respective unmarked tense forms are shown in Table 15. Note that Athpahariya, Belhare, Yakkha and Chintang share a presumably innovative exclusive morpheme $-\eta a \sim-\eta$ (cf. Ebert 1997a; Bickel 2003; Bickel et al. 2007a; Schackow 2015) and are therefore not listed in Table 15. Likewise, Yamphu expresses exclusivity by $-\eta a \sim-\eta \sim-i \eta$ (cf. Rutgers 1998: 110,130-132) and not, as its allegedly close relatives Mewahang and Lohorung, by $-k a$. The significance of this shared morphological trait between the alleged Upper Arun language Yamphu and the Greater Yakkha languages is a topic for future research. 
In the following, it will be argued that van Driem's assumption of separate plural and exclusive morphemes for Proto-Kiranti is unconvincing, since an exclusive morpheme * $k a$ can be reconstructed to a more ancient ancestor and since the data used by van Driem to argue for the reconstruction of the exclusive marker *-ya can be interpreted more convincingly as the result of lenition and analogy.

The existence of cognates for an exclusive morpheme *-ka outside of Kiranti constitutes an important piece of evidence against the reconstruction of two distinct morphological elements * $k$ and *-ya to Proto-Kiranti. According to DeLancey (2010:15-16), the exclusive marker - $k a$ found widely in Kiranti languages has a cognate in Jinghpaw, namely the first person plural suffix -ga?. DeLancey (2010: 16) also notes that a pronominal root \#ka is widespread in Trans-Himalayan as a first person plural form, often with exclusive meaning, and can be reconstructed to Proto-Trans-Himalayan (cf. also DeLancey 2018b). Consequently, van Driem's analysis of the formative - $k a$ in many Kiranti languages as being morphologically complex and going back to two distinct morphological entities in Proto-Kiranti is implausible. It is more elegant to assume that Kiranti languages have inherited the exclusive marker ${ }^{*}-k a$ and that the occurrence of an apparently separate exclusive element * $(y) a$ alongside a plural formative *- $k$ in certain Kiranti languages (cf. Table 15) should be analysed as an innovation of these languages. We shall briefly discuss the potential genesis of this vocalic exclusive morpheme, which involves lenition of original initial $k$ and analogical extension.

Certain Kiranti languages retain the inherited exclusive morpheme as $-k a$ in all forms, e.g. Bahing, Kulung or Nachiring. Others show evidence for the assumption for a step-wise lenition of the original exclusive morpheme $-k a>-g a>-w a>-a$ and the subsequent fusion of this vocalic suffix with the vowel of preceding suffixes. The initial lenition of $-k a>-g a$ in intervocalic position is attested for example in Mewahang or Limbu, which show a lenited exclusive marker $-g V$ in certain forms (cf. Table 15).

The further reduction of *-ka to $w a \sim a$ is attested in the dual forms of Kohi, Khaling, Dumi, Hayu, Jero and Bantawa, but in the first four languages, analogy has further blurred the original morphological structure, and we will therefore first comment on the development in Jero and Bantawa, before turning to these more complicated cases.

In the Âmbote dialect of Jero, first person non-singular is expressed by the suffixes - $y c i$ 'DU.INCL', -ycuwa 'DU.EXCL', -ki 'PL.INCL' and -kuwa 'PL.EXCL' (cf. Opgenort 2005: 142). Here, exclusivity is marked by $-w a$, which conceivably continues * $k a$, with lenition of the initial velar stop. The different vocalism of the suffixes preceding the exclusive marker may be attributed to a backening of $i$ due to the labiovelar glide $w$ of the exclusive marker. In the Mohantāre dialect of Jero, the exclusive forms are $-\eta c u$ and $-k u$ (cf. Opgenort 2005: 142), showing the further reduction and complete loss of the exclusive suffix, which only lives on in the different vowel quality of the exclusive morphemes. In Wambule, the closest relative of Jero, the non-singular first person indices are - $\eta c i$ 'DU.INCL', - $\eta c u k u$ 'DU.EXCL', -ki 'PL.INCL' and -ku 'PL.EXCL' (cf. Opgenort 2004a: 26o). The dual form shows the exclusive morpheme without lenition. The plural forms will be discussed below.

Bantawa, like Jero, shows evidence for complete reduction of the initial $k$ of the exclusive morpheme *-ka, namely in - $c a$ 'DU.EXCL' vs. - $c i$ 'DU.INCL' (cf. Doornenbal 2009: 145). The plural indices are -in 'PL.INCL' and -inka 'PL.EXCL' (cf. Doornenbal 2009: 145). Here, the plural form retains the original shape of the suffix, but in the dual, *-ka was lenited to $-a$ in intervocalic position and merged with the front vowel $i$ of the dual suffix $-c i$. This analysis is supported by the data from the closely related languages Puma and Chamling, both of which show the full exclusive suffix $-k a$ in both dual and plural (cf. Ebert 1997b: 17; Bickel et al. 2007b: 2).

Conceivably, the same lenition process took place in Hayu, Dumi, Kohi and Khaling, where the dual exclusive formatives -tsho(k), -it, -isu and - $u$ (cf. Michailovsky 1988: 81; van Driem 1993: 160-161; Lahaussois 
2009: 9; Jacques et al. 2012: 1102) can be analysed as deriving from the respective inclusive formatives -tshi(k), -i, -isi and - $i$ (cf. Michailovsky 1988: 81; van Driem 1993a:16o-161; Lahaussois 2009: 9; Jacques et al. 2012: 1102) plus a lenited form of the exclusive marker ${ }^{*}-k a$, i.e. Pre-Hayu ${ }^{*}-t s h i-\gamma a-k,{ }^{34}$ Pre-Dumi ${ }^{*} i-\gamma a$, Pre-Kohi *-isi-ya and Pre-Khaling *i- $z a$.

The plural forms of these four languages and Wambule probably show a case of analogical extension of the initial $k$ of the exclusive markers to the corresponding inclusive forms, which originally may have had the same form as in Nachiring, Puma or Mewahang, namely - $i$. Hence, Pre-Hayu, Pre-Dumi, PreKhaling and Pre-Kohi * $i$ gained an initial $k$ by analogy with the exclusive formative * $k a$ following the reanalysis of the initial $k$ - of the original exclusive marker as a marker of first person plurality and of its coda $-a$ as a marker of exclusivity, thus yielding the modern forms $-k e$ in Hayu and $-k i$ in Dumi, Khaling and Kohi. A piece of evidence that the plural forms came about by analogical extension of suffix-initial $k$ to the inclusive forms and not by lenition of former exclusive ${ }^{*}-k V-k a>{ }^{*}-k V-w a>-k o \sim-k a \sim-k n \sim-k o$ as in the dual forms, is the vowel quality in the exclusive morphemes of Dumi, Khaling and Kohi. All three languages show a different vowel quality in the dual exclusive and plural exclusive formatives, suggesting a different history of the morphemes in question. The lenition of the exclusive morpheme *-ka to -wa in the dual forms and the subsequent amalgamation with the inherent vowel of the dual suffixes led to a back high vowel $\dot{t} \sim u$, conceivably reflecting the merger of former ${ }^{*}-i w a .{ }^{35}$ The plural forms of Dumi, Khaling and Kohi, in contrast, simply reflect the outcomes of the inherited sequence ${ }^{*}-k a$, viz. $a \sim \jmath \sim \Omega$. The Wambule plural forms may reflect the same process of analogical extension, although the exclusive marker was not previously lenited in the dual.

Analogy may also be responsible for the Bahing plural morphemes, but here analogical remodelling of the plural inclusive form was based on the carrying over of the low vowel of the exclusive marker - $k a$ to the inclusive morpheme $-{ }^{*} i$, thus yielding ${ }^{*}-i-a>-y a$. Similarly, in Thulung, the past morpheme $-q$ in the plural inclusive form - $d i$ was carried over to the non-past form, i.e. ${ }^{*}-i>-d i$, by analogy. The original form ${ }^{*} i$ for first person plural inclusive non-past still sometimes appears alongside - $q i$ in the intransitive paradigm (Lahaussois 2002: 136) and is retained in the 1PL.INCL $\rightarrow 3$ non-past transitive configurations (Lahaussois 2002:138). The data from Bahing and Thulung, showing that analogical extension is common in the agreement morphology of Kiranti languages, supports our analysis of a spreading of $-k$ - to the inclusive plural forms in Hayu, Dumi, Khaling, Kohi and Wambule.

The importance of analogy seems to be underestimated in the reconstruction of Proto-Kiranti by van Driem (1990a), but is certainly an important factor in the development of the agreement morphology of Kiranti (cf. Jacques 2017: 210), and its consideration readily explains the inclusive-exclusive marking in Hayu, Dumi, Kohi or Khaling without the need to assume an exclusive marker *-ya and a separate plural marker *-k sensu van Driem (1990a). Our analysis of the inclusive-exclusive forms in Kiranti rather suggests that Dumi, Khaling, Kohi and Hayu exhibit shared innovations and may therefore be more closely related to each other, especially Dumi and Khaling, which share the innovative dual marker $-i$. Again, however, this would not include all the languages conventionally grouped under 'Western Kiranti' and would be in conflict with the distribution of the potential innovation * $k w>? w$ discussed in $\S 2.4$.

The final velar stop is the non-singular non-past marker of Hayu, which occupies the left-most slot of the verb syntagma, that is after the assumed original exclusive morpheme -ka (cf. Michailovsky 1988: 81; van Driem 1990a: 32). 
$\mathbf{1 \rightarrow 2}{ }^{*}-\boldsymbol{n}(\boldsymbol{y}) \boldsymbol{V}$ Another proposed morphological innovation for Kiranti is the portmanteau suffix * $n V$ ' $1 \rightarrow 2$ ' (cf. Jacques 2012: 84). Van Driem (1990a, 1993d) reconstructs a portmanteau suffix *-nya both for Proto-Kiranti and Proto-Tibeto-Burman. Jacques (2012), in contrast, views the suffix as a potential shared innovation of Kiranti languages. However, neither proposal can stand closer scrutiny.

The reconstruction of van Driem (1990: 40) of the suffix *-nya is based on data from Limbu, Dumi, Hayu, Kulung and Thulung. The phonetic shape of his reconstruction seems to be based primarily on Limbu, which exhibits the suffix $-n \varepsilon$, whereas the suffix has the form - $n$ in Dumi, -no in Hayu, -an in Kulung and -nini in Thulung as well as $-n(a)$ in Bahing (cf. van Driem 1991: 350). Lohorung has not preserved a reflex of Proto-Kiranti *<-nya>' (van Driem 1991: 350). However, a transitive relationship between a first person agent and a second person patient is marked in Lohorung by -na. If this is not a reflex of the assumed Proto-Kiranti index *-nya, we may also exclude the Dumi, Hayu, Kulung and Bahing morphemes. The Thulung morpheme -nini, according to Lahaussois (2002:138), is the suffix for the transitive

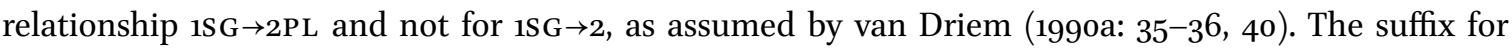
$1 S G \rightarrow 2 S G$ in Thulung is - $n i$ (cf. Lahaussois 2002: 138). The different vocalism of - $n i$ with regard to the second person singular intransitive ending -na does not reflect the fusion of the palatal glide and the vowel $a$ of a Proto-Kiranti morpheme *-nya, as implied by van Driem (1990a), but rather constitutes a characeristic trait of Thulung, also reflected in the $2 S G \rightarrow 1 S G$ form $-\eta i$ vs. first person singular intransitive $-\eta y u$. In sum, only the Limbu data suggests the reconstruction of a portmanteau suffix *-nya, and this is not sufficient evidence for a reconstruction to Proto-Kiranti.

Diachronically, the suffix *-nya/-nV is not a portmanteau suffix as assumed by both van Driem (1990a) and Jacques (2012). Rather, the restriction of this suffix, which is homophonous and etymologically identical to the second person singular intransitive ending in certain Kiranti languages, e.g. Mewahang, Wambule (cf. Opgenort 2004a: 260, 266, 309-310) or Sampang (Huysmans 2011: 185-186), to the configuration $1 \rightarrow 2$ reflects the ergative organisation of the agreement morphology in these languages (cf. van Driem 1997: 172). ${ }^{36}$ The morphological marking of the local scenarios $1 \rightarrow 2$ and $2 \rightarrow 1$ with the index of the respective patient is a widespread pattern in Trans-Himalayan (cf. DeLancey 2018a: 349). It is true that in several Kiranti languages, the original second person suffix $-n V$ is restricted to $1 \rightarrow 2$ transitive configurations and does not occur in other forms where it would be expected, i.e. $2 \rightarrow 3$ or intransitive forms. This, however, is attributable to analogical spreading of third person morphology to the respective second person forms, probably due to pragmatic factors, constituting a case of Watkin's Law (cf. Watkins 1962: 96; Benveniste 1946). In several Kiranti languages, second and third person are marked alike in the intransitive paradigm or the $\rightarrow 1$ or $\rightarrow 3$ transitive configurations, e.g. Hayu, Kulung, Mewahang or Yamphu (cf. Michailovsky 1988: 81-82; Tolsma 2006: 80-81; Rutgers 1998: 111-113). In certain Kiranti languages, this diachronic process led to the deletion of all instances of the second person morpheme $-n V$ except for the transitive configuration $1 \rightarrow 2$, e.g. Hayu, Kulung or Yamphu. In others, like Mewahang or Thulung (cf. Lahaussois 2002: 135-139), the second person index is retained in other forms, e.g. the intransitive conjugation or certain transitive configurations. Again in other languages like Lohorung, the second person index seems to have been secondarily added to certain forms, i.e. the $2 S G \rightarrow 1 S G$ transitive configuration, viz. -yana, due to analogy or, again, pragmatic reasons.

Another development is attested in languages which express second person with a prefix, i.e. $t V$ - in the southern Kiranti languages Bantawa, Puma or Chamling (cf. Ebert 1997b; Bickel et al. 2007b; Doornenbal

$36 \quad 1 \rightarrow 2$ configurations are expressed by the corresponding second person intransitive index, whereas $2 \rightarrow 1$ configurations are expressed by the corresponding first person intransitive index, e.g. Mewahang - $a \eta$ ' $1 \mathrm{SG}$ intransitive $=2 S \mathrm{SG} \rightarrow 1 \mathrm{SG}$ ' and $-n a$ '2SG intransitive $=1 S G \rightarrow 2 S G$ '. 
2009), $k \varepsilon$ - in Limbu (cf. van Driem 1987), $a$ - in Athpahariya and Chintang (cf. Ebert 1997a; Bickel et al. 2007a), $a$ - in Dumi (cf. van Driem 1993a) and $i$ - in Khaling (cf. Jacques et al. 2012). All these languages do not show the suffix $-n V$ in the intransitive conjugation. In these languages, the second person prefix ${ }^{*} t V$-, which is reconstructible to Proto-Trans-Himalayan (cf. DeLancey 2011: 4-14, 2014, Jacques 2012: 91-107), was generalised as second person index, whereas ${ }^{*}-n V$ was reanalysed as a marked second person index and restricted to $1 \rightarrow 2$ configurations. ${ }^{37}$

Second person morphology in Kiranti languages is an intriguing and historically as well as structurally complex topic, but neither the reconstruction of $* n(y) V$ to Proto-Kiranti nor the assumption that this constitutes a defining morphological or semantic innovation of the Kiranti languages can be maintained. ${ }^{38}$

Summary While the agreement morphology is certainly a promising field for the detection of shared innovations for all Kiranti languages, convincing evidence has not yet been brought forward. Indeed, Kiranti languages look strikingly similar in the overall organisation of their agreement morphology and the individual morphemes employed. But then, the same could be said when comparing individual Kiranti languages with Rgyalrong (cf. Jacques 2012: 86-87), Thangmi (cf. Turin 2012:5-9), Black Mountain Mönpa or Gongduk. ${ }^{39}$ Therefore, the use of similarity based merely on intuition and superficial inspection as evidence for closer relationship is no valid proceeding and must be replaced by a strict methodology looking for shared innovations.

\subsection{Discussion}

The review of the evidence in favour of a coherent Kiranti subgroup in this section reveals that a large and convincing body of evidence has not yet been provided and that, being methodologically strict, a single Kiranti node in the Trans-Himalayan family tree cannot yet be confirmed. These insights about the phylogeny of Kiranti languages are represented in Figure 3.

While the conventional 'Central-Eastern' group of the traditional Kiranti group can still be retained as a coherent subgroup based on the shared innovations discussed in section 2, the higher subgroup uniting the Central-Eastern and 'Western' Kiranti languages under a single proto-language cannot be sustained on the basis of the present empirical evidence. Therefore, the Kiranti node is dissolved in Figure 3, and the 'Central-Eastern' group as well as the polyphyletic 'Western Kiranti' languages are directly assigned to Proto-Trans-Himalayan, the ancestor not only of these groups, but also of all other Trans-Himalayan

37 The prefixes other than ${ }^{*} t V$-, namely Limbu $k \varepsilon$-, Dumi $a$ - and Khaling $i$-, can all be readily explained as secondary developments deriving from the respective possessive pronouns (Jacques 2012: 94-95) which replaced the original prefix ${ }^{*} t V$ (cf. Delancey 2011). The prefix $a$ - of Athpahariya and Chintang may also be derived from earlier ${ }^{*} t V$ - via deletion of the initial stop or may constitute another reconstructible morpheme (Jacques 2012: 97). Belhare and Yakkha exhibit an innovative second person suffix $-k a$, also appearing as prefix in Belhare in $2 \rightarrow 1 S G$ transitive configurations, which replaced original * $n V$ in the intransitive conjugation, whereas * $n V$ is still retained in 1 $\rightarrow 2$ forms ( cf. Bickel 2003: 551-553; Schackow 2015: 206, 218).

38 The reconstruction of this morpheme for Proto-Tibeto-Burman by van Driem (1993d: 321$)$ is not convincing either, since it is solely based on the Kiranti evidence and ambiguous Jinghpaw data.

39 Black Mountain Mönpa, a Trans-Himalayan language spoken in central Bhutan, exhibits a non-future second/third person index -ka (van Driem 1995: 237-239) similar to the innovative second person marker in Belhare and Yakkha. Gongduk exhibits a parallel to Wambule in its third person index, -di, which looks similar to the Wambule opaque third person agent element $-t i$ in the two transitive morphemes - $y a t i$ ' $3 S G \rightarrow 1 S G$ ' and -nati '3SG $\rightarrow 2 S G$ ' (cf. Opgenort 2004a: 310). 


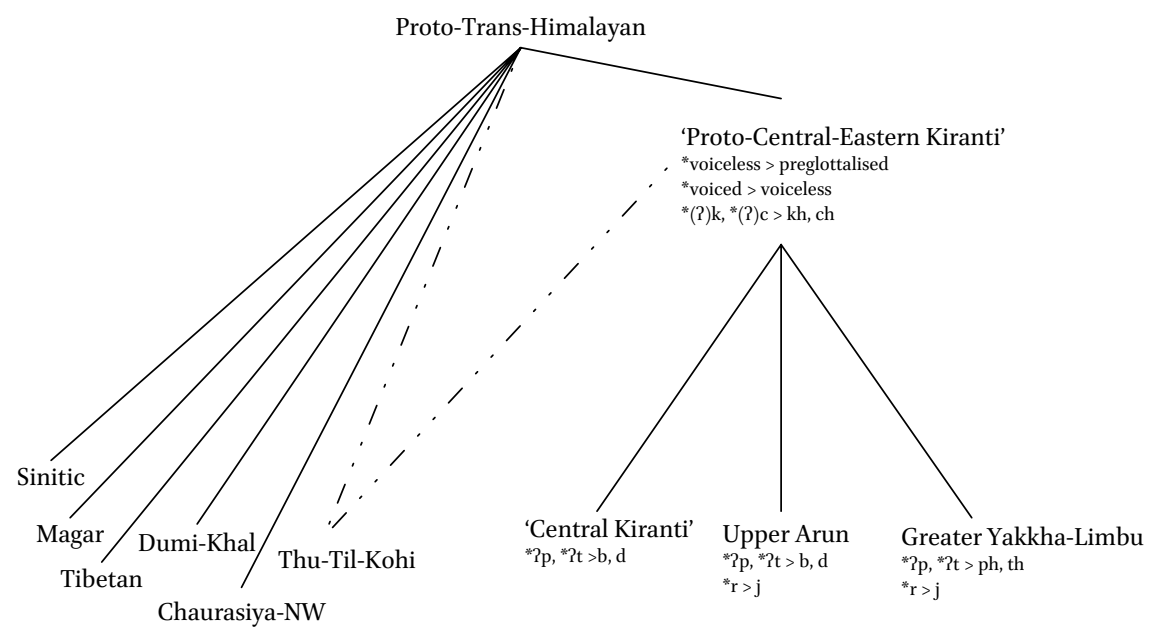

FIGURE 3 Summary of current knowledge about the phylogeny of Kiranti II

subgroups such as Sinitic, Magar or Tibetan, which are on a phylogenetic par with the different 'Western Kiranti' groups. The names 'Proto-Central-Eastern Kiranti' and 'Central Kiranti' are put in quotation marks in Figure 3, since these designations are based on the assumption of the phylogenetic coherence of the traditional Kiranti group and coined with regard to the geographical distribution of these languages within the assumed subgroup. With the revision and rejection of the unity of both the 'Western Kiranti' languages as well as the 'Kiranti' languages in general, these geographical names become obsolete, but may be retained to avoid terminological confusion. ${ }^{40}$

\section{4}

\section{Beyond 'Kiranti'}

In the past, there were certain proposals for a grouping of Kiranti with other branches of Trans-Himalayan, namely Kiranti-Newaric by van Driem (1992a, 1993c), Kiranti-Rgyalrong by Ebert (1990) or 'Rung', a higher subgroup first proposed by Thurgood (1984), including Rgyalrong, Qiangic, Nungish, Jinghpaw, Kham and Chepang with potential ties with Kiranti, and later modified to consist of Kiranti, West Himalayish, Rgyalrong and Nungish by LaPolla (2003b: 30). However, none of these proposals has stood the test of time, all of them being disregarded in most current work on historical-comparative linguistics on TransHimalayan or even refuted by later work, e.g. van Driem (2003) on Kiranti-Newar, Jacques (2012) on Kiranti-Rgyalrong and DeLancey (2010) on Rung as defined by LaPolla (2003b: 30). Furthermore, and more importantly for the present paper, none of these proposals questions the phylogenetic unity of Kiranti, as all of them link Kiranti as a whole to other language groups. A sole exception is Ebert (1990: 76), who speculates about a closer relationship between Eastern Kiranti and Rgyalrong and between

\footnotetext{
40 Another possibility, taking 'Upper Arun' as model, would be to use the names of the different rivers as names for the linguistic subgroups, given that the settlements of the individual subgroups correspond quite precisely to the individual rivers and that these rivers are of central importance for the peoples themselves, figuring prominently in their origin myths ( cf. section 5). Central Kiranti could consequently be called 'Sunkosi' or 'Sun-Dudhkosi' and Greater Yakkha-Limbu 'Tamur'. These names would be more agnostic and independent of the traditional notion 'Kiranti'.
} 
Khaling-Dumi and Nungish. ${ }^{41}$ The aim of this section is to suggest the possibility that certain subgroups of the traditional Kiranti branch may be more closely related to external language groups than to other Kiranti subgroups. The proposal that is provided here is a closer relationship between Central-Eastern Kiranti as defined above in Figure 2 and Lhokpu, Dhimal and Toto.

Lhokpu is spoken in Samtsi district in southwestern Bhutan and belongs to the oldest ethnolinguistic layer of Bhutan. Dhimal is spoken in Jhāpā and Morang districts in southeastern Nepal and a few adjacent villages in the Indian state of West Bengal. Toto is spoken in Jalpāīgudī district in West Bengal, India, close to the border with Bhutan. Dhimal and Toto are often viewed as close relatives (cf. King 2009: 3-4; van Driem 2015b: 142), but Grollmann/Gerber (2018) argue that an equally strong case can be made for Lhokpu-Dhimal on the basis of morphological evidence and that these three languages may form a subgroup, the internal structure of which remains a topic for future research. In Gerber et al. (2016), a closer relationship between Lhokpu and Kiranti is assumed on the basis of morphological evidence and certain lexical isoglosses. Most of the morphological body of evidence is given in Table 16.

In the domain of personal pronouns, Kiranti and Lhokpu share the etymological root with initial velar stop for first person. Furthermore, the possessive pronoun of Lhokpu, Dhimal, Toto, Yamphu and the oblique stem of the personal pronoun of Lohorung all exhibit the same opaque stem extension in $-\eta(a)$, possibly going back to an originally disyllabic pronominal form *kaya-. The second person plural pronoun kan of Lhokpu may be cognate to similar velar stop-initial second person singular pronouns in certain Kiranti languages. The validity of these similarities between Lhokpu and Eastern Kiranti is enhanced by the regular sound correspondence exhibited in the cognates, namely Lhokpu (and Dhimal and Toto) $k$ : Central-Eastern Kiranti $k$ : Western Kiranti $g$, which constitutes a potential shared phonological innovation of Lhokpu and Central-Eastern Kiranti, if the Lhokpu form, like the Central-Eastern Kiranti forms, is the result of the sound change *voiced > voiceless described by Michailovsky (1994).

In the domain of interrogative pronouns, Lhokpu shows a basic interrogative root with initial /h/, like Dhimal, Toto and most Kiranti languages. In Lhokpu and Dhimal, two interrogative pronouns with cognate suffixes take the extended stem het- $\sim$ he?. In Kiranti, no such alternation is observed, but Yakkha shows an identical stem het- $\sim$ he? for all interrogative pronouns, possibly a result of analogical levelling of a former opaque alternation like in Lhokpu or Dhimal.

In the domain of case morphology, certain Lhokpu morphemes find convincing cognates in different Kiranti languages, most of which belong to the Central-Eastern group. The same holds true for the domain of verbal morphology. Lhokpu and Toto do not exhibit biactantial agreement morphology as attested in Kiranti and Dhimal, but many Lhokpu morphemes which encode temporal, aspectual, modal or epistemic categories have potential cognates in Kiranti languages, although the picture of correspondences is somewhat fuzzy.

The similarities in the pronominal system are convincing and show regular sound correspondences which allow for the definition of a coherent subgroup including Lhokpu, Toto, Dhimal and CentralEastern Kiranti. Lhokpu, Dhimal and Toto can tentatively be grouped more closely together on the basis of morphological evidence brought forward by Grollmann/Gerber (2018). This is reflected in Figure 4.

The affiliation of Lhokpu-Dhimal-Toto with Central-Eastern is represented by a dotted line due to the tentative nature of the evidence. Whereas the first and second person pronouns indicate that Lhokpu,

41 According to Ebert (1990: 76), the evidence for Khaling-Dumi-Nungish is weak and needs to be elaborated. This proposal does not seem to have found any followers. The Eastern-Kiranti-Rgyalrong proposal, on the other hand, can be considered falsified since Jacques ( 2012) has shown that the similarities between Kiranti and Rgyalrong are due to shared retention rather than shared innovation. 
TABLE 16 Similarities between Lhokpu, Kiranti, Dhimal and Toto

\begin{tabular}{|c|c|c|c|}
\hline Lhokpu & Kiranti & Dhimal & Toto \\
\hline$k a$ '1SG' & $\begin{array}{l}\text { Yamphu ka, Lohorung ka, Yakkha ka, } \\
\text { Kulung koy, Chamling kaya, Thulung } \\
\text { go, Sunwar go, Hayu gu(u) '1SG' }\end{array}$ & $k a$ '1SG' & $k a$ '1SG' \\
\hline kaya '1sG.Poss' & $\begin{array}{l}\text { Yamphu kay- '1SG.Poss', Lohorung } \\
\text { kaya '1SG.овL' }\end{array}$ & $\operatorname{ka\eta }(k o)$ '1SG.Poss' & koy '1SG.POss' \\
\hline kan '2PL' & 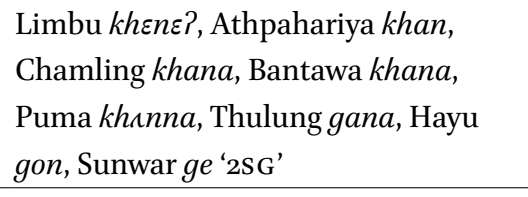 & - & - \\
\hline $\begin{array}{l}\text { Interr. root he- with } \\
\text { opaque stem het-in the } \\
\text { pronouns for 'which' } \\
\text { and 'when' }\end{array}$ & $\begin{array}{l}\text { Interr. root } h V \text { - in most Kiranti } \\
\text { languages, } h e t-\sim h e ?-\text { in Yakkha, but } \\
\text { no alternation }\end{array}$ & $\begin{array}{l}\text { Interr. root } h e-\text {, with } \\
\text { opaque stem he?-in the } \\
\text { pronouns for 'when' and } \\
\text { 'how many' }\end{array}$ & $\begin{array}{l}\text { Interr. root } h a(N) \text {-, } \\
\text { but no alternation }\end{array}$ \\
\hline$-(?) a^{\prime} \mathrm{ERG}$ & Kiranti in general $-(?) a$ & - & -ha 'ERG' \\
\hline -lok'овј’ & $\begin{array}{l}\text { Athpahariya-Belhare -lok 'com', } \\
\text { Kulung -lo 'com' }\end{array}$ & - & - \\
\hline -lek 'DIR' & $\begin{array}{l}\text { Athpahariya-Belhare -ley 'DIR', Yakkha } \\
\text {-lley 'ADV' }\end{array}$ & - & - \\
\hline$-s u$ 'СOM’ & $\begin{array}{l}\text { Lohorung -su 'also', Yamphu -so 'too', } \\
\text { Kulung so 'also' }\end{array}$ & $\begin{array}{l}\text {-su } \\
\text { 'collective-reciprocal' }\end{array}$ & - \\
\hline - $d u$ 'LOC.ARC', -te 'ALL' & Kiranti in general - $D V^{\prime}$ LOC.UPW' & $-t a$ 'LOC' & $-t a^{\prime} \mathrm{LOC}^{\prime}$ \\
\hline$-n u$ 'COND' & Kiranti in general $-n V$ & -nu 'COND' & - \\
\hline$-i$ 'AD H' & Kiranti in general $-i$ & - & - \\
\hline$d o(\eta)$ 'DUR' & 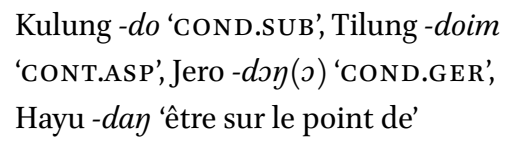 & -doy 'PROG' & -day 'AUX.PROG' \\
\hline$-y a k \sim-y a \eta$ 'PT.AFF' & $\begin{array}{l}\text { Athpahariya -yak(t)- 'telic/certainity } \\
\text { postverb', Belhare -yak(t) 'IPFV', } \\
\text { Yamphu yag-/yaks- yak- 'departure/ } \\
\text { exploitation AUx', Bantawa yak- } \\
\text { yay- 'copula', Chintang -yakt 'IPFV' }\end{array}$ & - & - \\
\hline$-y u$ 'VOL' & $\begin{array}{l}\text { Athpahariya }-y u(k) \text { 'NPT', Belhare -yuk } \\
\text { 'definitive NPT', Bantawa -yuk(t)- 'neg- } \\
\text { ative past perfect AUX,' Hayu -yu 'oPT' }\end{array}$ & - & - \\
\hline - $e$ 'IMP’ vS. - $O$ 'IMP.POL' & $\begin{array}{l}\text { Limbu - } \varepsilon \text { ? 'IMP' vs. - } \text { ?o: 'PE.IMP', } \\
\text { Khaling - } e \text { vs. }-\theta\left(<{ }^{*}-o\right)\end{array}$ & $\begin{array}{l}\text {-se 'IMP.DU' vs. -su } \\
\text { 'IMP.PL' }\end{array}$ & - \\
\hline
\end{tabular}

Dhimal and Toto participated in the sound change *voiced > voiceless characteristic of Central-Eastern Kiranti and other cognates in the lexicon confirm this assumption, the evidence for the participation of Lhokpu, Dhimal and Toto in the other sound changes defining for Central-Eastern, namely *voiceless > preglottalised and *(?)k and *(?)c $>k h$ and $c h$, is meagre. Rather, Lhokpu, Dhimal and Toto predominantly 


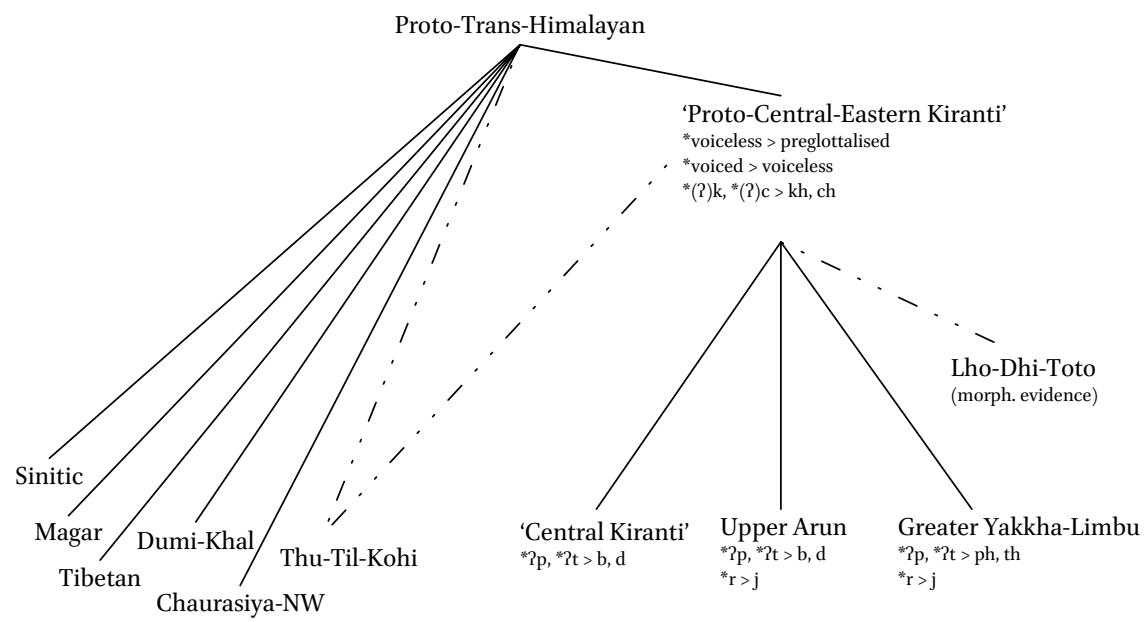

FIGURE 4 Summary of current knowledge about the phylogeny of Kiranti III

show a voiceless stop where a voiced or aspirated would be expected, giving the outcomes in CentralEastern Kiranti (cf. $§ 2.6$ ).

This leads to problems with the chronology of sound changes. The group consisting of Thulung, Tilung and Kohi share the sound change *voiceless > preglottalised with Central-Eastern, but not the sound change *voiced > voiceless, whereas Lhokpu, Dhimal and Toto share this latter sound change with CentralEastern, but not the former one (cf. Figure 4). Therefore, not all of these languages can be subsumed under a common intermediate ancestor. A potential solution to this problem is to assume that Lhokpu, Dhimal and Toto did in fact participate in the sound change *voiceless $>$ preglottalised, but that the outcome were plain voiceless stops, that is the same change that is assumed by Opgenort for Western Kiranti under the assumption that preglottalised stops need to be reconstructed to Proto-Kiranti (cf. § 2.4). Another solution would be to exclude either Thulung-Tilung-Kohi or Lhokpu-Dhimal-Toto from the Central-Eastern subgroup and to explain the respective shared sound change as a parallel, independent innovation or an areally spread feature.

The parallels between Lhokpu, Dhimal-Toto and Kiranti still need to be carefully investigated and the assumption of a closer relationship remains hypothetical. However, it is insightful to see that certain languages which are not part of the conventional Kiranti group are equally close or even closer to certain Kiranti languages than these are to other subgroups of the conventional Kiranti group. This provides further evidence that the conventional Kiranti subgroup can be a misleading and questionable phylogenetic entity.

This paper examined the phylogeny of the Kiranti group with regard to its internal classification and with regard to its status as a subgroup of the Trans-Himalayan family. Several conclusions are to be drawn from this examination.

First, a critical assessment of various proposals on the internal classification of conventional Kiranti subgroups has shown that the languages called 'Western Kiranti' by Michailovsky (1994) do not share a common innovation, but constitute a residue group in relation to the non-Western Kiranti languages. The non-Western or Eastern/Central-Eastern languages can be defined by three shared phonological 
developments in the stops, i.e. the changes *voiceless $>$ preglottalised, ${ }^{*}$ voiced $>$ voiceless and ${ }^{*} ? k$, ${ }^{*} ? c>k h$, $c h$. Following the methods of historical-comparative linguistics, the non-Western languages therefore constitute a coherent subgroup. The further subgrouping of Kiranti languages is ambiguous and allows for several solutions, since the phonological developments do not bundle neatly. The possible classifications are evaluated in $\S 2.6$ and the most elegant solution is represented in figure 2 .

Second, the validity of Kiranti as a monophyletic subgroup cannot be substantiated due to the lack of innovations shared by all 'Kiranti' languages, whereas the Central-Eastern languages, as defined in this paper in $\S 2.6$, form a coherent subgroup defined by the sound changes mentioned above. The monophyletic unity of all 'Kiranti' languages, thus, cannot be taken for granted at the present stage of research. In order to argue convincingly for certain subgroups within Kiranti or for the monophyletic status of Kiranti, Kirantologists need to consider more languages in comparative work, adapt a bottom-up approach to smaller groups and provide more evidence, especially in the form of morphological aberrancies. So far undescribed or ignored languages need to be considered to reach at convincing reconstructions and classifications of smaller groups. A strict application of the comparative method and consideration of the desiderata given here may be able to resolve the ambiguities encountered in the internal classification of Kiranti (see $\S 2.6$ ) and to answer the question whether Kiranti is a monophyletic subgroup of Trans-Himalayan.

Third, research on Lhokpu, Dhimal and Toto shows that these languages may belong to the same phylogenetic group as the 'Central-Eastern Kiranti' languages. This would extend this group beyond the traditional conception of 'Kiranti'.

Although non-linguistic arguments are not valid for phylogenetic subgrouping, it is noteworthy that the links between Dhimal and the traditional 'Kiranti' group go beyond the linguistic domain. In an origin myth shared by many Kiranti peoples, there are four brothers migrating from a mythological place of origin and wandering along different rivers to reach their present dwelling place. Although the names of the four brothers differ from version to version, three of them usually have names resembling the names of nowadays' 'Kiranti' groups, whereas the fourth brother usually has a name reminiscent of an ethnic group living in the southern planes of Nepal known as Tarai (cf. Gaenszle 1991: 292-306; Rutgers 1998: 408-414; Nicoletti 2006: 77-79; Ebert/Gaenszle 2008)

In the version of the Mewahang, described in detail by Gaenszle (1991: 292-306) and Ebert/Gaenszle (2008: 171-180), the names of the three elder brothers are Khambuhang, Mewahang and Limbuhang/ Metnahang, who together moved from the plains in the south towards the north, each following one of the major rivers, Dudhkosi, Arun and Tamur. The three brothers and their progeny correspond neatly to the three ethnolinguistic groups Khambu, Upper Arun and Limbu (?+Greater Yakkha). The youngest brother, called Koche or Meche, stayed behind in the planes and has lived there ever since. Mewahang speakers vividly state that the Tarai people are brothers and sisters of the Kiranti people, explicitly referring to the Dhimal, among others. Likewise, the Dhimal see themselves as close relatives, namely as 'younger brothers', of the Rai and Limbu people in the north (cf. King 2009: 2). Although this is not evidence for a closer linguistic relationship, it is interesting from an ethnolinguistic perspective. Whatever the details of their migration and ethnic history, it is important to note that the self-identification of the 'Kiranti' people does reach beyond the traditional definition. Ebert/Gaenszle (2008:12-13) illustrate how elements of mythological narration common to the Rai peoples are also encountered in the myths of other Tibeto-Burman communities of the Himalayas, e.g. Gurung, Magar, Taraon Mishmis, Minyong and even of the Indo-Aryan speaking Tharu. ${ }^{42}$

42 Note that the Thangmi, a Trans-Himalayan group of central Nepal, have a very similar origin myth as the Kiranti, with five brothers, representing the forefathers of different Himalayan groups, being forced to leave their hometown and two 
By taking into consideration that a convincing body of evidence for a coherent Kiranti subgroup in the traditional sense is very hard to find, it is even more striking that the 'Kiranti' languages have been traditionally and unchallengedly been treated as a monophyletic subgroup of Trans-Himalayan. Reasons for this are the obvious superficial similarities between the 'Kiranti' languages and the traditional view of an ethnic unity of the Kiranti people. Both arguments disqualify for a historical-comparative classification. The linguistic similarities chiefly concern typological features and not shared innovations and are thus of purely impressionistic nature. Furthermore, it has been shown that the alleged ethnic coherence is mainly based on relatively recent exonymic designations (see $§ 3.1$ ) and that the self-perception reaches in some cases well beyond the traditional 'Kiranti' unit (see above).

If, however, the genetic unity between the 'Kiranti' languages is assumed, the question has to be raised why the presentation of sound linguistic evidence is so difficult. One explanation might be very intense language contact which may have blurred the genetic innovations of the group. This is a valid argument, but it immediately triggers the question as to whether this intense contact might have been responsible for making these languages so similar to each other in the first place and whether the impression of a genetic relation actually derives from this contact situation. The Kiranti languages may therefore constitute a Sprachbund sensu Trubetzkoy (1930).

In general, we have shown in this paper that independent and contact-induced shared innovations have to be postulated in any case and that language contact may have played a greater role than assumed so far. The possibility that language contact with its various effects, e.g. phonological assimilation, loan words and morphological calques, paradigmatic regularisation and levelling, and shared retentions may be responsible for the majority of the similarities between the Kiranti languages should be taken into account in future comparative investigations. In this regard, Winter's (1986a: 9) questions on the phylogeny of Kiranti are instructive:

Gibt es eine genetisch zu interpretierende Gruppe der Kiranti-Sprachen? Ist statt dessen ein Kettenmodell vorzuziehen, das vom Sunwar und Vayu über Rai bis zum Limbu reicht, zumindest einen Teil der Gemeinsamkeiten aber nicht auf aus einer gemeinsamen Quelle Überkommenes, sondern auf Verbreitung durch Kontakt in Raum und Zeit zurückführt? Oder ist statt des Entweder-Oder ein Sowohl-Als-Auch vorzuziehen, und wo liegen die Grenzen der beiden Komponenten?

Our aim here was to show that the endeavour to prove a coherent Kiranti subgroup in a methodologically strict way has so far not been successful. This does not mean that the comparative method cannot be used for the Kiranti languages, but, on the contrary, that it should be applied more strictly. Although we are of the opinion that future comparative research may finally succeed in proving the Kiranti subgroup, at the time being, the dominant notion of a coherent Kiranti branch may at times be hindering rather than helpful, and it may be worth looking beyond this unproven concept in order to find the historical reality.

\section{List of Abbreviations}

1 'First person', 2 'Second person', 3 'Third person', $\rightarrow$ 'Transitive relation', A 'Agent', ADH 'Adhortative', ADV 'Adverbial', AfF 'Affirmative', ARC 'Archaic', ASP 'Aspectualiser', Aux 'Auxiliary', caus 'Causative', com

of them wandering along the rivers Sunkosi and Tamakosi. These two brothers are identified as the ancestors of the Thangmi and of the Rai people (Turin 2012: 110-111). 
'Comitative', cond 'Conditional', cont 'Continuous', cop 'Copula', Dir 'Directional', Du 'Dual', DUR 'Durative', EQT 'Equative', ERg 'Ergative', EXCL 'Exclusive', GER 'Gerund', IMP 'Imperative', INCH 'Inchoative', INCL 'Inclusive', IN F 'Inferred', IPFV ‘Imperfective', LOC 'Locative', Ms 'Marked-scenario', NEG 'Negative', nPt 'Non-past', nsg 'Non-singular', овј 'Object', овL 'Oblique', орт 'Optative', P 'Patient', PE 'Pre-emptive', PERF 'Performative', PK 'Proto-Kiranti,' PL 'Plural', pol 'Polite', poss 'Possessive', prog 'Progressive', Prs 'Present', Pт 'Past', Ртв 'Proto-Tibeto-Burman', Refl 'Reflexive', sG 'Singular', sub 'Subordinator', uPw 'Upwards' and vol 'Volitional'.

\section{Acknowledgment}

We are grateful to Scott DeLancey, Nathan Hill, George van Driem, Tanja Gerber and two anonymous reviewers for valuable and helpful comments. We would also like to say alay and olanu to our Kiranti consultants.

\section{References}

Allen, Nicholas J. (1972). ‘The vertical dimension in Thulung classification'. In: Journal of the Anthropological Society of Oxford 3. 81-94.

Allen, Nicholas J. (1975). Sketch of Thulung grammar with Three Texts and a Glossary. Ithaca: Cornell University. (Cornell University East Asia Papers, vol. 6).

Andvik, Erik (2010). A Grammar of Tshangla. Leiden/Boston: Brill. (Languages of the Greater Himalayan Region, vol. 10).

Bauman, James John (1974). 'Pronominal Verb Morphology in Tibeto-Burman'. In: Linguistics of the Tibeto-Burman Area 1.1. 108-155.

Bauman, James John (1975). Pronouns and Pronominal Morphology in Tibeto-Burman. Berkeley: University of California's Ph.D. Thesis.

Baxter, William H./Laurent Sagart (2014a). 'Baxter-Sagart Old Chinese reconstruction, version 1.1 (2o September 2014)'. List of Old Chinese reconstructions.

Baxter, William H./Laurent Sagart (2014b). Old Chinese. A New Reconstruction. Oxford: Oxford University Press.

Benedict, Paul K. (1972). Sino-Tibetan. A Conspectus. Cambridge: Cambridge University Press.

Benedict, Paul K. (1973). 'Tibeto-Burman Tones. With a Note on Teleo-Reconstruction'. In: Acta Orientalia 35. 127-138.

Benveniste, Emile (1946). 'Structure des relations de personne dans le verbe'. In: Bulletin de la Société de Linguistique de Paris $43.1-12$.

Bickel, Balthasar (1996). Aspect, Mood, and Time in Belhare. Studies in the Semantics-Pragmatics Interface of a Himalayan Language. Zürich: Universität Zürich's Ph.D. Thesis. (Arbeiten des Seminars für Allgemeine Sprachwissenschaft, vol. 15).

Bickel, Balthasar (1997). 'Spatial operations in deixis, cognition, and culture. Where to orient oneself in Belhare'. In: Nuyts, Jan/Eric Pederson eds. Language and conceptualization. Cambridge: Cambridge University Press. 46-83.

Bickel, Balthasar (1999). 'Nominalization and focus constructions in some Kiranti languages'. In: Yadava, Yogendra P./Warren W. Glover eds. Topics in Nepalese Linguistics. Kathmandu: Royal Nepal Academy. 271-296.

Bickel, Balthasar (2001). 'Deictic transposition and referential practice in Belhare'. In: Journal of Linguistic Anthropology 10. 224-247. 
Bickel, Balthasar (2003). ‘Belhare’. In: Thurgood, Graham/Randy J. LaPolla eds. The Sino-Tibetan languages. London/ New York: Routledge. 546-570.

Bickel, Balthasar/Goma Banjade/Martin Gaenszle/Elena Lieven/Netra Prasad Paudyal/Ichchha Purna Rai/ Manoj Rai/Novel Kishore Rai/Sabine Stoll (2007a). 'Free Prefix Ordering in Chintang'. In: Language 83.1. 43-73.

Bickel, Balthasar/Martin Gaenszle (2015). 'First person objects, antipassives, and the political history of the Southern Kirant'. In: Journal of South Asian Languages and Linguistics 2.1. 63-86.

Bickel, Balthasar/Martin Gaenszle/Arjun Rai/Prem Dhoj Rai/Shree Kumar Rai/Vishnu S. Rai/Narayan P. Sharma (2007b). 'Two ways of suspending object agreement in Puma: between incorporation, antipassivization, and optional agreement'. In: Himalayan Linguistics 7. 1-18.

Blench, Roger/Mark W. Post (2014). 'Rethinking Sino-Tibetan phylogeny from the perspective of North East Indian languages'. In: Owen-Smith, Thomas/Nathan W. Hill eds. Trans-Himalayan Linguistics. Historical and descriptive linguistics of the Himalayan Area. Berlin/Boston: De Gruyter. (Trends in Linguistics, vol. 266). 71-104.

Bloomfield, Leonard (1925). 'On the Sound-System of Central Algonquian'. In: Language 1.4. 130-156.

Bloomfield, Leonard (1928). 'A Note on Sound-Change'. In: Language 4.2. 99-100.

Blust, Robert A. (1970). 'Proto-Austronesian Addenda'. In: Oceanic Linguistics 9.2. 104-162.

Blust, Robert A. (1980). 'Austronesian Etymologies'. In: Oceanic Linguistics 19.1/2. 1-181/183-189.

Blust, Robert A. (1983). 'Austronesian Etymologies: II'. In: Oceanic Linguistics 22/23.1/2. 29-149.

Blust, Robert A. (1986). 'Austronesian Etymologies: III'. In: Oceanic Linguistics 25.1/2.1-123.

Blust, Robert A. (1989). 'Austronesian Etymologies: IV'. In: Oceanic Linguistics 28.2. 111-180.

Blust, Robert A. (1991). 'The Greater Central Philippines Hypothesis'. In: Oceanic Linguistics 30.2. 73-129.

Blust, Robert A. (1993). 'Central and Central-Eastern Malayo-Polynesian'. In: Oceanic Linguistics 32.2. 241-293.

Borchers, Dörte (2008). A Grammar of Sunwar. Descriptive Grammar, Paradigms, Texts and Glossary. Leiden/Boston: Brill. (Languages of the Greater Himalayan Region, vol. 5.7).

Bowern, Claire/Harold Koch eds. (2004). Australian languages: classification and the comparative method. Amsterdam: John Benjamins.

Bradley, David (2002). 'The subgrouping of Tibeto-Burman'. In: Beckwith, Christopher ed. Medieval Tibeto-Burman Languages. Leiden: Brill. $73^{-112 .}$

Brandstetter, Renward (1893). Die Beziehungen des Malagasy zum Malaiischen. Luzern: E. Haag.

Campbell, Lyle/William J. Poser (2008). Language Classification. History and Method. Cambridge: Cambridge University Press.

Caughley, Ross (2000). Dictionary of Chepang. A Tibeto-Burman language of Nepal. Canberra: Pacific Linguistics. (Pacific Linguistics, vol. 502).

Coupe, Alexander R. (2007). A Grammar of Mongsen Ao. Berlin/New York: Mouton de Gruyter. (Mouton Grammar Library, vol. 39).

Crowley, Terry (1991). 'Parallel Development and Shared Innovation: Some Developments in Central Vanuatu Inflectional Morphology'. In: Oceanic Linguistics 30.2. 179-222.

DeLancey, Scott (1989). 'Verb agreement in Proto-Tibeto-Burman'. In: Bulletin of the School of Oriental and African Studies 52.2. 315-333.

DeLancey, Scott (1992). 'Sunwar copulas'. In: Linguistics of the Tibeto-Burman Area 15.1. 31-38.

DeLancey, Scott (2003). 'Lhasa Tibetan'. In: Thurgood, Graham/Randy J. LaPolla eds. The Sino-Tibetan Languages. London/New York: Routledge. 270-288.

DeLancey, Scott (2010). 'Towards a History of Verb Agreement in Tibeto-Burman'. In: Himalayan Linguistics 9.1. $1-39$. 
DeLancey, Scott (2011). 'Notes on verb agreement prefixes in Tibeto-Burman'. In: Himalayan Linguistics 10.1. 1-29.

DeLancey, Scott ( 2013). 'Verb agreement suffixes in Mizo-Kuki-Chin'. In: Hyslop, Gwendolyn/Stephen Morey/Mark W. Post eds. North East Indian Linguistics 5. Delhi et al.: Cambridge University Press India. 138-150.

DeLancey, Scott (2014). 'Second person verb forms in Tibeto-Burman'. In: Linguistics of the Tibeto-Burman Area 37.1. $3-33$.

DeLancey, Scott (2015). 'Morphological Evidence for a Central Branch of Trans-Himalayan (Sino-Tibetan)'. In: Cahiers de Linguistique Asie Orientale 44.2. 122-149.

DeLancey, Scott (2018a). 'Deictic and sociopragmatic effects in Tibeto-Burman SAP indexation'. In: Cristofaro, Sonia/Fernando Zúñiga eds. Typological Hierarchies in Synchrony and Diachrony. Amsterdam: John Benjamins. $345^{-375}$.

DeLancey, Scott (2018b). 'The inclusive-exclusive distinction in Kuki-Chin and Naga Belt Languages'. In: Konnerth, Linda/Stephen Morey/Teo Amos eds. North East Indian Linguistics. Vol. 8. Canberra: Asia Pacific Linguistics. $75^{-85}$.

Dempwolff, Otto (1934-1938). Vergleichende Lautlehre des austronesischen Wortschatzes. 3 vols. Berlin: Reimer. (Zeitschrift für Eingeborenen-Sprachen, Supplement 1-3).

Dixon, R. M. W. (1997). The rise and fall of languages. Cambridge: Cambridge University Press.

Doornenbal, Marius (2009). A Grammar of Bantawa. Grammar, paradigm tables, glossary and texts of a Rai language of Eastern Nepal. Utrecht: LOT.

Durie, Mark/Malcolm Ross eds. (1996). The Comparative Method Reviewed. Regularity and Irregularity in Language Change. Oxford: Oxford University Press.

Ebert, Karen H. (1990). 'On the evidence for the relationship Kiranti-Rung'. In: Linguistics of the Tibeto-Burman Area 13.1. 57-78.

Ebert, Karen H. (1991). 'Inverse and pseudo-inverse prefixes in Kiranti languages'. In: Linguistics of the TibetoBurman Area 14.1. 73-92.

Ebert, Karen H. (1993). 'Kiranti subordination in the south Asian areal context'. In: Ebert, Karen H. ed. Studies in clause linkage. Zürich: Arbeiten des Seminars für Allgemeine Sprachwissenschaft. 83-110.

Ebert, Karen H. (1997a). A Grammar of Athpare. München/Newcastle: Lincom Europa. (Lincom Studies in Asian Linguistics, vol. 1).

Ebert, Karen H. (1997b). Camling. München/Newcastle: Lincom Europa. (Languages of the World/Materials, vol. 103).

Ebert, Karen H. (1999). 'The up-down dimension in Rai grammar and mythology'. In: Bickel, Balthasar/Martin Gaenszle eds. Himalayan space: Cultural horizons and practices. Zürich: Völkerkundemuseum der Universität Zürich. 109-140.

Ebert, Karen H. (2003). 'Kiranti Languages. An Overview'. In: Thurgood, Graham/Randy J. LaPolla eds. The SinoTibetan Languages. 505-517.

Ebert, Karen H./Martin Gaenszle (2008). Rai Mythology. Cambridge/London: Harvard University Press.

Faber, Alice (1997) . 'Genetic Subgrouping of the Semitic Languages'. In: Hetzron, Robert ed. The Semitic Languages. London/New York: Routledge. ${ }^{-15}$.

François, Alexandre (2015). 'Trees, waves and linkages. Models of language diversification'. In: Bowern, Claire/Bethwyn Evans eds. The Routledge Handbook of Historical Linguistics. London/New York: Routledge. 161-189.

Gaenszle Martin (1991). Verwandtschaft und Mythologie bei den Mewahang Rai in Ostnepal. Stuttgart: Steiner Verlag. (Beiträge zur Südasienforschung, Südasien-Institut, Universität Heidelberg, vol. 136). 
Gaenszle, Martin (2002). 'Countering the Great Traditions. Remaking of the Kiranti Past'. In: Harneit-Sievers, Axel ed. A Place in the World. New Local Historiographies from Africa and South Asia. Leiden/Boston/Köln: Brill. 331-346.

Genetti, Carol (1988). 'Notes on the structure of the Sunwar transitive verb'. In: Linguistics of the Tibeto-Burman Area 11.2. 62-69.

Genetti, Carol (1992). 'Segmental alternations in the Sunwari verb stem: a case for the feature [front]'. In: Linguistics an Interdisciplinary Journal of Language Science 30.2. 317-358.

Genetti, Carol (2016). 'The Tibeto-Burman languages of South Asia'. In: Hock, Hans Henrich/Elena Bashir eds. The Languages and Linguistics of South Asia. Berlin: De Gruyter Mouton. (The World of Linguistics, vol. 7).130-155. Gerber, Pascal/Tanja Gerber/Selin Grollmann (2016). 'Links between Lhokpu and Kiranti: some observations'. (Paper presented at the Kiranti Workshop, Paris: CNRS Université Paris Diderot, 1-2 December 2016).

Greenberg, Joseph H. (1987). Language in the Americas. Stanford: Stanford University Press.

Greenberg, Joseph H. (2000). 'The concept of proof in genetic linguistics'. In: Gildea, Spike ed. Reconstructing grammar: comparative linguistics and grammaticalization. Amsterdam: John Benjamins. 161-175.

Grierson, George ed. (1909). Linguistic Survey of India. Tibeto-Burman Family. General Introduction, Specimens of the Tibetan Dialects, the Himalayan Dialects, and the North Assam Group. Vol. 3.1. Delhi/Varanasi/Patna: Motilal Banarsidass.

Grollmann, Selin (2018). 'A first field report on Nachiring (Kiranti)'. In: Himalayan Linguistics 17.1. 1-18.

Grollmann, Selin/Pascal Gerber (2018). 'Lingustic evidence for a closer relationship between Lhokpu and Dhimal. Including some notes on Dhimalish subgroup'. In: Cahiers de Linguistique Asie Orientale 47.1. 1-96.

Hanßon, Gerd (1991). The Rai of Eastern Nepal: Ethnic and Linguistic Grouping. Findings of the Linguistic Survey of Nepal. Kirtipur: Linguistic Survey of Nepal/Centre for Nepal/Asian Studies, Tribhuvan University.

Harrison, S. P. (2003). 'On the Limits of the Comparative Method'. In: Joseph, D. Brian/Richard D. Janda eds. The Handbook of Historical Linguistics. Malden: Blackwell. 213-243.

Hetzron, Robert (1972). Ethiopian Semitic: Studies in Classification. Manchester: Manchester University Press. (Journal of Semitic Studies Monograph, vol. 2).

Hetzron, Robert (1973). 'The Vocalization of Prefixes in Semitic Active and Passive Verbs'. In: Mélanges de l'Université Saint Joseph 48. 35-48.

Hetzron, Robert (1975). 'Genetic Classification and Ethiopian Semitic'. In: Bynon, J./T. Bynon eds. Hamito-Semitica. The Hague: Mouton. 103-127.

Hetzron, Robert (1976). ‘Two Principles of Genetic Reconstruction'. In: Lingua 38. 89-104.

Hill, Nathan W. (2009). 'Review of Handbook of Proto-Tibeto-Burman: System and Philosophy of Sino-Tibetan Reconstruction. By James A. Matisoff. Berkeley: University of California Press, 2003.' In: Language and Linguistics 10.1. 173-195.

Hill, Nathan W. (2011). 'An Inventory of Tibetan Sound Laws'. In: Journal of the Royal Asiatic Society of Great Britain and Ireland. 3 rd ser. 21.4. 441-457.

Hill, Nathan W. (2012). 'The Six Vowel Hypothesis of Old Chinese in Comparative Context'. In: Bulletin of Chinese Linguistics 6.2. 1-69.

Hill, Nathan W. (2019). The Historical Phonology of Tibetan, Burmese, and Chinese. Cambridge: Cambridge University Press.

Hodgson, Brian Houghton (1856). 'Aborigines of the Nilgiris with remarks on their affinities'. In: Journal of the Asiatic Society of Bengal $25 \cdot 498-522$.

Hodgson, Brian Houghton (1857). 'Comparative Vocabulary of the Languages of the broken Tribes of Népál'. In: Journal of the Asiatic Society of Bengal 26. 317-522. 
Hodgson, Brian Houghton (1858). 'On the Kiránti Tribe of the Central Himalaya'. In: Journal of the Asiatic Society of Bengal 27. 446-456.

Huehnergard, John (1991). 'Remarks of the Classification of the Northwest Semitic Languages'. In: Hoftijzier, J./G. van der Kooij eds. The Balaam Text from Deir 'Alla Re-evaluated. Proceedings of the International Symposium held at Leiden, 21-24 August 1989. Leiden: Brill. 282-293.

Huysmans, René (2011). 'The Sampang Verbal Agreement System'. In: Turin, Mark/Bettina Zeisler eds. Himalayan Language and Linguistics. Studies in Phonology, Semantics, Morphology and Syntax. Leiden/Boston: Brill. (Brill's Tibetan Studies Library, vol. 5.12). 183-218.

Jacques, Guillaume (2010). 'A possible trace of verbal agreement in Tibetan'. In: Himalayan Linguistics 9.1. 41-49.

Jacques, Guillaume (2012). 'Agreement Morphology. The Case of Rgyalrongic and Kiranti'. In: Language and Linguistics 13.1. 83-116.

Jacques, Guillaume (2017). 'A reconstruction of Proto-Kiranti verb roots'. In: Folia Linguistica Historica 38. 177-215. Jacques, Guillaume/Aimée Lahaussois (2014). 'The auditory demonstrative in Khaling'. In: Studies in Language 38.2. 393-404.

Jacques, Guillaume/Aimée Lahaussois/Boyd Michailovsky/Dhan Bahadur Rai (2012). 'An Overview of Khaling Verbal Morphology'. In: Language and Linguistics 13.6. 1095-1170.

Jäschke, Heinrich August (1881). A Tibetan-English Dictionary. with special reference to the prevailing dialects to which is added an English-Tibetan vocabulary. London: Unger Brothers.

King, John T. (2009). A Grammar of Dhimal. Leiden/Boston: Brill. (Languages of the Greater Himalayan Region, vol. $8)$.

Lahaussois, Aimée (2002). Aspects of the grammar of Thulung Rai. An endangered Himalayan language. Berkeley: University of California's Ph.D. Thesis.

Lahaussois, Aimée (2003). 'Nominalization and its various uses in Thulung'. In: Linguistics of the Tibeto-Burman Area 26.1. 33-57.

Lahaussois, Aimée (2009). 'Koyi Rai. An initial grammatical sketch'. In: Himalayan Linguistics Archive 4. 1-33.

LaPolla, Randy J. (1989). 'Verb agreement, head-marking vs. dependent-marking, and the "deconstruction" of Tibeto-Burman morpho-syntax'. In: Hall, Kira ed. Proceedings of the fifteenth annual meeting of the Berkeley Linguistics Society. Berkeley: Berkeley Linguistics Society. 356-367.

LaPolla, Randy J. (1992). 'On the dating and nature of verb agreement in Tibeto-Burman'. In: Bulletin of the School of Oriental and African Studies 55.2. 298-315.

LaPolla, Randy J. (1994). 'Parallel Grammaticalizations in Tibeto-Burman Languages. Evidence of Sapir's “Drift”. In: Linguistics of the Tibeto-Burman Area 17.1. 61-80.

LaPolla, Randy J. (2001). 'The role of migration and language contact in the development of the Sino-Tibetan language family'. In: Aikhenvald, Alexandra/R. M. W. Dixon eds. Areal diffusion and genetic inheritance. Oxford: Oxford University Press. 225-254.

LaPolla, Randy J. (2003a). A Grammar of Qiang. With annotated texts and glossary. Berlin/New York: Mouton de Gruyter. (Mouton Grammar Library, vol. 31).

LaPolla, Randy J. (2003b). 'Overview of Sino-Tibetan morphosyntax'. In: Thurgood, Graham/Randy J. LaPolla eds. London/New York: Routledge. 22-42.

LaPolla, Randy J. (2012). 'Comments on Methodology and Evidence in Sino-Tibetan Comparative Linguistcs'. In: Language and Linguistics 13.1. 117-132.

Matisoff, James A. (1993). 'Sangkong of Yunnan. Secondary "verb pronominalization" in Southern Loloish'. In: Linguistics of the Tibeto-Burman Area 16.2. 123-142. 
Matisoff, James A. (2003). Handbook of Proto-Tibeto-Burman. System and Philosophy of Sino-Tibetan Reconstruction. Berkeley/Los Angeles/London: University of California Press. (University of California Publications in Linguistics, vol. 135).

Meillet, Antoine (1925). La méthode comparative en linguistique historique. Oslo: H. Aschehoug \& Co.

Michailovsky, Boyd (1975). 'Notes on the Kiranti verb (East Nepal)'. In: Linguistics of the Tibeto-Burman Area 2.2. $183^{-218 .}$

Michailovsky, Boyd (1988). La Langue Hayu. Paris: Éditions du Centre National de la Recherche Scientifique.

Michailovsky, Boyd (1994). 'Manner versus place of articulation in the Kiranti initial stops'. In: Kitamura, Hajime/Tatsuo Nishida/Yasuhiko Nagano eds. Current Issues in Sino-Tibetan Linguistics. Osaka: The Organizing Committee of the 26th International Conference on Sino-Tibetan Languages and Linguistics. $766-781$.

Michailovsky, Boyd (2017). 'Kiranti Languages'. In: Thurgood, Graham/Randy J. LaPolla eds. The Sino-Tibetan Languages. Second edition. London/New York: Routledge. 646-679.

Nichols, Johanna (1992). Linguistic diversity in time and space. Chicago: University of Chicago Press.

Nicoletti, Martino (2006). The Ancestral Forest. Memory, Space and Ritual among the Kulunge Rãi of Eastern Nepal. Kathmandu: Vajra Publications.

Nishi, Yoshio (1995). 'A Brief Survey of the Controversy in Verb Pronominalization in Tibeto-Burman'. In: Nishi, Yoshio/James A. Matisoff/Yasuhiko Nagano eds. New Horizons in Tibeto-Burman Morphosyntax. Osaka: National Museum of Ethnology. (Senri Ethnological Studies, vol. 41). 1-16.

Opgenort, Jean Robert (2004a). A Grammar of Wambule. Grammar, Lexicon, Texts and Cultural Survey of a Kiranti Tribe of Eastern Nepal. Leiden/Boston: Brill. (Languages of the Greater Himalayan Region, vol. 5.2).

Opgenort, Jean Robert (2004b). 'Implosive and preglottalized stops in Kiranti'. In: Linguistics of the Tibeto-Burman Area 27.1.1-27.

Opgenort, Jean Robert (2005). A Grammar of Jero. With a Historical Comparative Study of the Kiranti Languages. Leiden/Boston: Brill. (Languages of the Greater Himalayan Region, vol. 5·3).

Opgenort, Jean Robert (2011). 'A note on Tilung and its position within Kiranti'. In: Himalayan Linguistics 10.1. 253-271.

Opgenort, Jean Robert (2014). 'Initial Grammatical Sketch of Tilung. Field Report on a Moribund Kiranti Language of Eastern Nepal. With some Historical Observations and a Vocabulary'. In: Owen-Smith, Thomas/Nathan W. Hill eds. Trans-Himalayan Linguistics. Historical and descriptive linguistics of the Himalayan Area. Berlin/Boston: De Gruyter. (Trends in Linguistics, vol. 266). 329-392.

Plaisier, Heleen (2007). A Grammar of Lepcha. Leiden/Boston: Brill. (Languages of the Greater Himalayan Region, vol. 5.5).

Rai, Netra Mani (2017). A Grammar of Dumi. München: Lincom. (Languages of the World/Materials, vol. 509).

Rāī, Noval Kiśora/Manoj RāīNetra Prasād Pauḍyāl/Roberț Śikovski/Bālthājār Bikal/Sabīne Sṭol/Mārțin Gyānsle/Gomā Banjāḍe/Icchā Pūrṇa Rāī/Toyā Nātha Bhaț̣a/Sebāsțiyān Sāuppe/Rikhī Māyā Rāì/Janak Kumārī Rāī/Lās Kumārī Rāī/Durgā Bahādur Rāì/Ganeś Rāī/Dayārām Rāī/Durgā Kumārī Rāī/Atitā Rāī/Candra Kumārī Rāi/Sānti Māyā Rāī/Ravendra Kumār Rāī/Juḍī Pețigru/Ṭīko Ḍirksamāyar (VS 2067 [2011]). Chintāin śabdakoś tathā vyākaran [Chintang dictionary and grammar]. Lalitpur: Chintang Language Research Program, Tribhuvan University Kathmandu/University of Leipzig.

Rutgers, Roland (1998). Yamphu. Grammar, Texts and Lexicon. Leiden: Research School CNWS. School of Asian, African, and Amerindian Studies. (Languages of the Greater Himalayan Region, vol. 2).

Sagart, Laurent (2006). 'Handbook of Proto-Tibeto-Burman: System and philosophy of Sino-Tibetan reconstruction. By James A. Matisoff'. In: Diachronica 23.1. 206-223. 
Sapir, Edward (1913). 'Southern Paiute and Nahuatl, a study in Uto-Aztekan'. In: Journal de la Société des Américanistes 10.2. 379-425.

Sapir, Edward (1915). 'Southern Paiute and Nahuatl. A Study in Uto-Aztekan. Part II'. In: American Anthropologist 17.1. $98-120$.

Schackow, Diana (2015). A grammar of Yakkha. Berlin: Language Science Press. (Studies in Diversity Linguistics, vol. 7).

Schackow, Diana/Balthasar Bickel/Shree Kumar Rai/Narayan P. Sharma/Arjun Rai/Martin Gaenszle (2012). 'Morphosyntactic properties and scope behavior of "subordinate" clauses in Puma (Kiranti)'. In: Gast, Volker/Holger Diessel eds. Clause linkage in cross-linguistic perspective. Berlin: De Gruyter Mouton. 105-126.

Schmidt, Johannes (1872). Die Verwandtschaftsverhältnisse der indogermanischen Sprachen. Weimar: H. Böhlau.

Schuchardt, Hugo (1885). Ueber die Lautgesetze. Gegen die Junggrammatiker. Berlin: R. Oppenheim.

Shafer, Robert (1953). 'East Himalayish'. In: Bulletin of the School of Oriental and African Studies 15.2. 356-374.

Shafer, Robert (1955). 'Classification of the Sino-Tibetan Languages'. In: Word 11.1. 94-111.

Shafer, Robert (1974). Introduction to Sino-Tibetan. Wiesbaden: Otto Harrasowitz.

Sharma, Narayan Prasad (2014). Morphosyntax of Puma, a Tibeto-Burman language of Nepal. London: SOAS, University of London's Ph.D. Thesis.

Singh Rai, Vishnu Prasad (2012). A Grammar of Chamling. Bern: University of Bern's Ph.D. Thesis.

Starostin, Sergei (1994). 'The reconstruction of Proto-Kiranti'. (Paper presented at the 27 th International Conference on Sino-Tibetan Languages and Linguistics, Paris: Centre International d'Études Pédagogiques à Sèvres, 14 October 1994).

Sun, Hongkai (1995). 'A Further Discussion on Verb Agreement in Tibeto-Burman'. In: Nishi, Yoshio/James A. Matisoff/Yasuhiko Nagano eds. New Horizons in Tibeto-Burman Morphosyntax. Osaka: National Museum of Ethnology. (Senri Ethnological Studies, vol. 41). 17-29.

Thomason, Sarah G. (2001). Language Contact. Washington: Georgetown University Press.

Thurgood, Graham (1984). 'The "Rung” Languages: A Major New Tibeto-Burman Subgroup'. In: Proceedings of the Tenth Annual Meeting of the Berkeley Linguistics Society. 338-349.

Thurgood, Graham (2003). 'A Subgrouping of the Sino-Tibetan Languages. The Interaction between language contact, change and inheritance'. In: Thurgood, Graham/Randy J. LaPolla eds. The Sino-Tibetan Languages. London/ New York: Routledge. $3^{-21}$.

Thurgood, Graham/Randy J. LaPolla eds. (2003). The Sino-Tibetan Languages. London/New York: Routledge.

Tolsma, Gerard Jacobus (2006). A Grammar of Kulung. Leiden/Boston: Brill. (Languages of the Greater Himalayan Region, vol. 5.4).

Tournadre, Nicolas (2014). 'The Tibetic languages and their classification'. In: Hill, Nathan W./Thomas Owen-Smith eds. Trans-Himalayan Linguistics. Berlin/Boston: Mouton de Gruyter. (Trends in Linguistics, vol. 266). 105-129.

Trubetzkoy, Nicolai (1930). 'Proposition 16'. In: Actes du premier congrès international de linguists à La Haye, du 10-15 avril 1928. 17-18.

Turin, Mark (2012). A Grammar of the Thangmi Language. With an Ethnolinguistic Introduction to the Speakers and Their Culture. 2 vols. Leiden/Boston: Brill. (Languages of the Greater Himalayan Region, vol. 5.6).

van Boxhorn, Marcus Zuerius (1647). Antwoord van Marcus Zuerius van Boxhorn Gegeven op de Vraaghen, hem voorgestelt over de Bediedinge van de Afgodinne Nehalennia, onlancx uytgegeven. In welcke de ghemeine herkomste van der Griecken, Romeinen, ende Duytschen Tale uyt den Scythen duydelijck bewesen, ende verscheiden Oudheden van dese Volckeren grondelijck ontdeckt ende verklaert. Leyden: Willem Christiaens van der Boxe. 
van der Auwera, Johan/Frens Vossen (2017). 'Kiranti double negation. A copula conjecture'. In: Linguistics of the Tibeto-Burman Area 40.1. 40-58.

van Driem, George. 'A Grammar of Lohorung'. Unpublished manuscript a.

van Driem, George. 'Black Mountain Mönpa'. Unpublished manuscript b.

van Driem, George. 'The Țoṭo language of the Bhutanese duars. being first impressions of the Ṭoṭo language and reflections on the Western Tibeto-Burman hypothesis'. Unpublished manuscript c.

van Driem, George (1987). A Grammar of Limbu. Berlin/New York/Amsterdam: Mouton de Gruyter. (Mouton

Grammar Library, vol. 4).

van Driem, George (1988). 'The verbal morphology of Dumi Rai simplicia'. In: Linguistics of the Tibeto-Burman Area

11.1. 134-207.

van Driem, George (1990a). 'An exploration of Proto-Kiranti verbal morphology'. In: Acta Linguistica Hafniensia 22.

$27-48$.

van Driem, George (199ob). 'The Fall and Rise of the Phoneme /r/ in Eastern Kiranti: Sound Change in Tibeto-

Burman'. In: Bulletin of the School of Oriental and African Studies 53.1. 83-86.

van Driem, George (1991). 'Bahing and the Proto-Kiranti Verb'. In: Bulletin of the School of Oriental and African

Studies 54.2. 336-356.

van Driem, George (1992a). 'In Quest of Mahākirāntī' In: Contributions to Nepalese Studies. Journal of the Centre of

Nepal and Asian Studies of Tribhuvan University 19.2. 241-247.

van Driem, George (1992b). 'Le proto-kiranti revisité, morphologie verbale du lohorung'. In: Acta Linguistica

Hafniensia 24. 33-75.

van Driem, George (1993a). A Grammar of Dumi. Berlin/New York: Mouton de Gruyter. (Mouton Grammar Library, vol. 10).

van Driem, George (1993b). 'Einige Bemerkungen zum Aspekt im Limbu'. In: Linguistische Berichte 148. 483-489.

van Driem, George (1993c). 'The Newar verb in Tibeto-Burman perspective'. In: Acta Linguistica Hafniensia 26.

23-43.

van Driem, George (1993d). 'The Proto-Tibeto-Burman Verbal Agreement System'. In: Bulletin of the School of

Oriental and African Studies 56.2. 292-334.

van Driem, George (1994). 'The Yakkha verb: interpretation and analysis of the Omruwa material (a Kiranti language of eastern Nepal)'. In: Bulletin of the School of Oriental and African Studies 57.2. 347-355.

van Driem, George (1995). 'Black Mountain Conjugational Morphology, Proto-Tibeto-Burman Morphosyntax, and

the Linguistic Position of Chinese'. In: Nishi, Yoshio/James A. Matisoff/Yasuhiko Nagano eds. New Horizons in

Tibeto-Burman Morphosyntax. Osaka: National Museum of Ethnology. (Senri Ethnological Studies, vol. 41). 229-259.

van Driem, George (1997). 'A new analysis of the Limbu verb'. In: Bradley, David ed. Tibeto-Burman Languages of the Himalayas. Canberra: Pacific Linguistics. (Papers in Southeast Asian Linguistics, vol. 14). 153-173.

van Driem, George (1998). Dzongkha. Leiden: Research School CNWS. School of Asian, African, and Amerindian

Studies. (Languages of the Greater Himalayan Region, vol. 1).

van Driem, George (2001). Languages of the Himalayas. An Ethnolinguistic Handbook of the Greater Himalayan

Region. 2 vols. Leiden/Boston/Köln: Brill.

van Driem, George (2002). 'Tibeto-Burman replaces Indo-Chinese in the 199os. Review of a decade of scholarship'.

In: Lingua 111. 79-102.

van Driem, George (2003). 'Mahakiranti revisited: Mahakiranti or Newaric?' In: Kansakar, Tej Ratna/Mark Turin eds. Themes in Himalayan Languages and Linguistics. Heidelberg/Kathmandu. 21-26. 
van Driem, George (2005). 'Tibeto-Burman vs. Indo-Chinese. Implications for population geneticists, archaeologists and prehistorians'. In: Laurent, Sagart/Roger Blench/Alicia Sanchez-Mazas eds. The peopling of East Asia: Putting Together the Archaeology, Linguistics and Genetics. London: Routledge Curzon. 81-106.

van Driem, George (2011). 'Tibeto-Burman subgroups and historical grammar'. In: Himalayan Linguistics 10.1. 31-39.

van Driem, George (2013). 'Biactantial agreement in the Gongduk transitive verb in the broader Tibeto-Burman context'. In: Thornes, Timothy J./Erik Andvik/Gwendolyn Hyslop/Joana Jansen eds. Functional-Historical Approaches to Explanation. In honor of Scott DeLancey. Amsterdam: John Benjamins. (Typological Studies in Language, vol. 103). 69-81.

van Driem, George (2015a). 'Synoptic grammar of the Bumthang language. A language of the central Bhutan highlands'. In: Himalayan Linguistics Archive 6. 1-77

van Driem, George (2015b). 'Tibeto-Burman'. In: Wang, William S.-Y./Chaofen Sun eds. Oxford Handbook of Chinese Linguistics. Oxford: Oxford University Press. 135-148.

Wang, William S.-Y. (1969). 'Competing Changes as a Cause of Residue'. In: Language 45.1. 9-25.

Watkins, Calvert (1962). Indo-European Origins of the Celtic Verb. Volume I: The Sigmatic Aorist. Dublin: Institute for Advanced Studies.

Watters, David E. (2008). 'Nominalization in the Kiranti and Central Himalayish languages of Nepal'. In: Linguistics of the Tibeto-Burman Area 31.2. 1-44.

Weidert, Alfons/B. Subba (1985). Concise Limbu Grammar and Dictionary. Amsterdam: Lobster.

Weinreich, Uriel/William Labov/Marvin I. Herzog (1968). 'Empirical Foundations for a Theory of Language Change'. In: Lehmann, Winfried P./Yakov Malkiel eds. Directions for Historical Linguistics. Austin: University of Texas Press. 95-195.

Winter, Werner (1986a). 'Aus der Arbeit des Linguistic Survey of Nepal'. In: Kölver, Bernhard ed. Formen kulturellen Wandels und andere Beiträge zur Erforschung des Himālaya. Sankt Augustin: VGH Wissenschaftsverlag. 453-459.

Winter, Werner (1986b). 'Bantawa $r V$ - < ?. An exercise in internal and comparative reconstruction'. In: Kastovsky, Dieter/Aleksander Szwedek eds. Linguistics across Historical and Geographical Boundaries. In Honour of Jacek Fisiak on the Occasion of His Fiftieth Birthday. 2 vols. Berlin/New York/Amsterdam: Mouton de Gruyter. 763-772.

Winter, Werner (1987). 'Differentation within Rai: Non-lexical isoglosses' In: Laycock, Donald C./Werner Winter eds. A World of Language: Papers presented to Professor S. A. Wurm on his 65th Birthday. Canberra: Pacific Linguistics. 729-734.

Winter, Werner (1991). 'Diversity in Rai languages: An inspection of verb stems in selected idioms'. In: Lingua Posnaniensis 34. 141-156.

Wylie, Turrell (1959). 'A Standard System of Tibetan Transcription'. In: Harvard Journal of Asiatic Studies 22. $261-267$. 


\section{評述「奇蘭特」語}

Pascal Gerber

Institut für Sprachwissenschaft, Universität Bern

pascal.gerber@isw.unibe.ch

Selin Grollmann

Institut für Sprachwissenschaft, Universität Bern

selin.grollmann@isw.unibe.ch

\section{摘要}

尼泊爾東部分佈有一群習稱「奇蘭特」的語言。本文對其譜系關係的傳統看法提出挑戰。一般認為這些語 言屬於「跨喜馬拉雅語系」之下的單系語支, 但支持的實證卻極為有限。雖有數篇相關研究問世, 所謂 $「$ 奇蘭特語支」的次分類架構依然晦澀不明。本文宗旨在於廣泛檢討文獻上幾種不同的次分類方案, 以及足 以界定「奇蘭特語」為「跨喜馬拉雅語系」下位單系語支的共同創新。另外，分布於 $「$ 奇蘭特」地區以外 有幾個語言, 它們與部分奇蘭特語的關係, 或許比後者與其他奇蘭特語的關係更加接近。總之, $「$ 奇蘭特 語支」基本上屬於尚待確立的語言團體, 「跨喜馬拉雅語系」的研究者, 不宜不加批判便全盤接受這種假 說。

\section{關鍵詞}

奇蘭特語、歷史比較語言學、共同創新、語言親緣關係、語言次分類、跨喜馬拉雅 語系 